\title{
4. TURBIDITY-CURRENT OVERSPILL FROM THE AMAZON CHANNEL: TEXTURE OF THE SILT/ SAND LOAD, PALEOFLOW FROM ANISOTROPY OF MAGNETIC SUSCEPTIBILITY AND IMPLICATIONS FOR FLOW PROCESSES ${ }^{1}$
}

\author{
Richard N. Hiscott, ${ }^{2}$ Frank R. Hall, ${ }^{3}$ and Carlos Pirmez ${ }^{4}$
}

\begin{abstract}
On the Amazon Fan, the meandering Amazon Channel is flanked by levees tens of meters to $>100 \mathrm{~m}$ high. Grain-size characteristics of the thicker and coarser grained spillover turbidites recovered by coring of the levees can be used to infer the nature of the suspended load and velocity of Pleistocene turbidity currents that transited the channel. Magnetic-mineral alignments in these turbidites provide estimates of flow directions of the overspilling currents. Together, these data augment our understanding of the development and maintenance of large submarine channels. The grain size of spillover turbidites from 10 to $50 \mathrm{~m}$ below the seafloor at Ocean Drilling Program Sites 939, 940, 934, 936, 944, and 946 was determined using a Sedigraph 5100 particle-size analyzer. The magnetic alignments were determined by measuring anisotropy of magnetic susceptibility using a Kappabridge KLY-2 susceptibility meter.

From the upper to the lower fan, the median size increases and the levee height decreases. Paleoflow during overspill was at a high angle to levee crests, but with considerable dispersion. Paleoflow data can only be properly interpreted in conjunction with information on the local channel shape and the position of low points, or saddles, in the adjacent levee crest. Comparison of (1) the texture of spillover turbidites with (2) grain sizes of sand in the talweg of the Amazon Channel, (3) independent velocity estimates based on differential levee heights, and (4) suspension theory, leads to the conclusion that a single type of mixed-load turbidity current could have transported very coarse sand as bedload along the talweg and contributed to levee growth by spilling a suspension of mainly silt and mud from the flow top. While transiting the Amazon Channel, such turbidity currents were constantly entraining seawater, but were losing a greater volume of dilute suspension from the flow top through overspill. As a result, there is a thirtyfold decrease in channel cross-sectional area from the upper fan to the lower fan. On the lower fan, with levee heights less than $25 \mathrm{~m}$, even some of the sand load from the lower part of turbidity currents was lost to overspill.
\end{abstract}

\section{INTRODUCTION}

Large submarine channels have captured the imagination of marine sedimentologists since they were first described from the deep oceans (Menard, 1955), and more recently when side-scan sonar imagery indicated the meandering nature of many of these channels (e.g., Damuth et al., 1983a). A full explanation for meander development and the long-distance flow of turbidity currents through meandering channels remains elusive, although several scenarios have been proposed (Chough and Hesse, 1976; Hay, 1987; Normark and Piper, 1991; Clark et al., 1992; Pirmez, 1994; Clark and Pickering, 1996). The importance of overspill from channelized turbidity currents has long been recognized as the fundamental process governing levee growth. As explained by Komar (1973, p. 3332): "At any one position along the channel, overspill would bring up the channel relief until perhaps only the very largest turbidity currents would be capable of overspilling the channel. The relief therefore would reflect the thickness of larger than average flows."

During Ocean Drilling Program (ODP) Leg 155, six sites were drilled into the levees of the Amazon Channel (Fig. 1). The Leg 155 cores provide samples through the levees of a major deep-sea channel at several locations along its length, so that characteristics of overspilling turbidity currents can be assessed. An underlying objective of the research reported in this paper was to acquire the types of data from the levee turbidites that might allow inferences to be made

'Flood, R.D., Piper, D.J.W., Klaus, A., and Peterson, L.C. (Eds.), Proc. ODP, Sci. Results, 155: College Station, TX (Ocean Drilling Program).

${ }^{2}$ Earth Sciences Department, Memorial University of Newfoundland, St. John's, Newfoundland, A1B 3X5, Canada. rhiscott@kean.ucs.mun.ca

${ }^{3}$ College of Marine Studies, University of Delaware, Newark, DE 19716, U.S.A.

${ }^{4}$ Lamont-Doherty Earth Observatory, Borehole Research Group, Palisades, NY 10964, U.S.A. about the overspill process itself and about the vertical structure and flow mechanics of the turbidity currents that flowed downfan within the Amazon Channel. We have targeted the coarser grained silt and fine-sand turbidites, so that our conclusions relate to the most vigorous turbidity currents that transited the channel. Our laboratory measurements consist of grain-size determinations to constrain flow velocities, and anisotropy of magnetic susceptibility measurements to estimate paleoflow directions.

Except for Site 936, the six sites considered in this paper are all situated on the right-hand levee of the Amazon Channel. A complete levee succession was cored at each site. Except for Site 946, all of the levee sequences have a 10- to 25-m-thick fine-grained cap deposited during the latest Pleistocene to Holocene sea-level rise. Below this cap and down to about $50 \mathrm{~m}$ below the seafloor (mbsf) at each site (Fig. 2), interbedded and interlaminated sand, silt, and mud turbidites represent the overspill record from the Amazon Channel after the time of the latest major avulsion along the channel (i.e., after the Aqua and Brown phases of channel development; see Manley and Flood, 1988; Pirmez and Flood, 1995). Only Site 946 is well downfan from the site of this latest avulsion. All the other sites discussed in this paper were areas of active levee growth well before the Amazon phase of channel development.

Average sedimentation rates during active growth phases of the Amazon Channel levees can be estimated using biostratigraphic data, and by identifying paleomagnetic excursions and secular-variation cycles. These rates are extremely high at $1-2.5 \mathrm{~cm} / \mathrm{yr}$ (Flood, Piper, Klaus, et al., 1995, p. 18), suggesting a recurrence interval for overspilling turbidity currents of perhaps one to a few years during the Pleistocene. The Amazon Channel is the most recently active channel of the Amazon Fan. Along its centerline, the channel has a length of about $1000 \mathrm{~km}$. SeaBeam bathymetric maps in Pirmez (1994) show details of the morphology of this channel downslope from the Amazon Canyon, over a centerline length of $\sim 700 \mathrm{~km}$. This distance is 
Figure 1. Leg 155 sites discussed in this paper, superimposed on a map of the Amazon Fan bathymetry, including SeaBeam coverage of the Amazon Channel. The SeaBeam survey area is contoured every $50 \mathrm{~m}$, regional contours every $500 \mathrm{~m}$. Channel stratigraphy is according to the nomenclature of Manley and Flood (1988) and Pirmez (1994). Bathymetry in uncorrected meters $(v=$ $1.5 \mathrm{~km} / \mathrm{s})$.

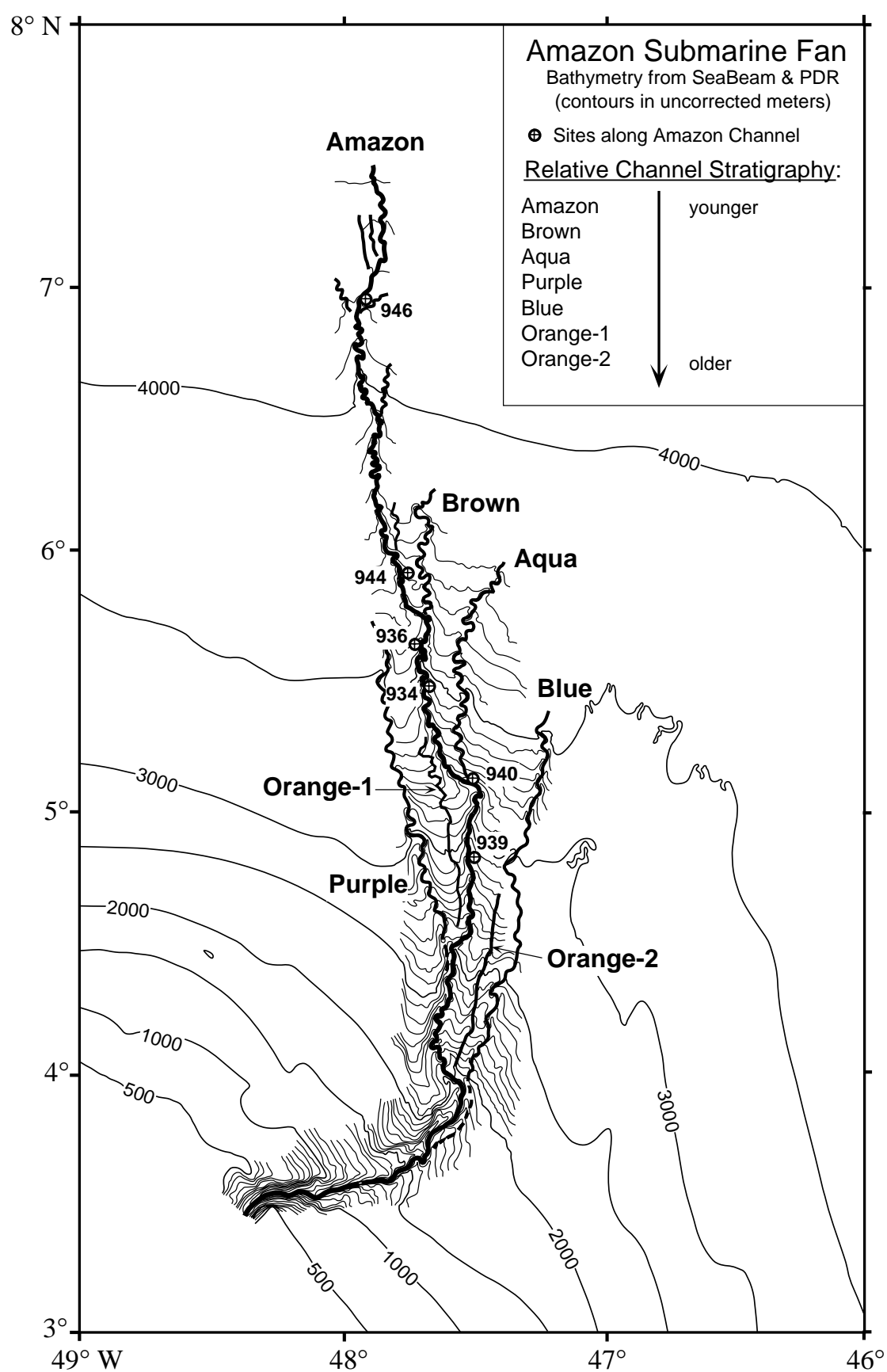

$\sim 280 \mathrm{~km}$ greater than the straight-line distance between the start and end points of the channel in the SeaBeam survey area. The difference between the centerline length and the straight-line distance is the result of high channel sinuosity (Pirmez and Flood, 1995; Pirmez, 1994). Pirmez and Flood (1995) divide the Amazon Fan into an upper, middle, and lower fan based on whether the channel talweg is deeper than the interchannel area (upper and lower fan regions) or shallower (middle fan). On the middle fan, the entire channel-levee architectural element is perched above the surrounding seafloor.

Pirmez and Flood (1995) provide quantitative data on the morphology of the Amazon Channel. They refer all measurements to distances along the centerline of the channel, with zero distance being $100 \mathrm{~km}$ landward of the end of the Amazon Canyon. We use the same distance scale in this paper. The gradient along the channel centerline decreases from about $8 \mathrm{~m} / \mathrm{km}$ near the canyon-channel transition, to about $1 \mathrm{~m} / \mathrm{km}$ near the distal end of the channel. The channel has a concave upward, graded longitudinal profile like mature rivers, and is most sinuous where the regional slope-to-basin gradient is in the range of 3-7 m/km. Along this part of the channel, sinuosity is directly proportional to regional gradient, with the result that tighter meandering tends to reduce the effects of steeper regional gradients and to smooth fluctuations in the channel gradient along its centerline. The highest channel sinuosity of $\sim 1.5$ to 2.7 is found $250-600 \mathrm{~km}$ along the channel centerline (Pirmez, 1994).

Pirmez (1994) and Pirmez and Flood (1995) hypothesized that the morphology of the Amazon Channel was delicately adjusted to the characteristics of Pleistocene turbidity currents that flowed through the channel (e.g., flow concentrations, thicknesses, velocities). Soon after flow initiation, the opposing processes of overbank spill from the dilute top of a turbidity current (flow stripping of Piper and Nor- 


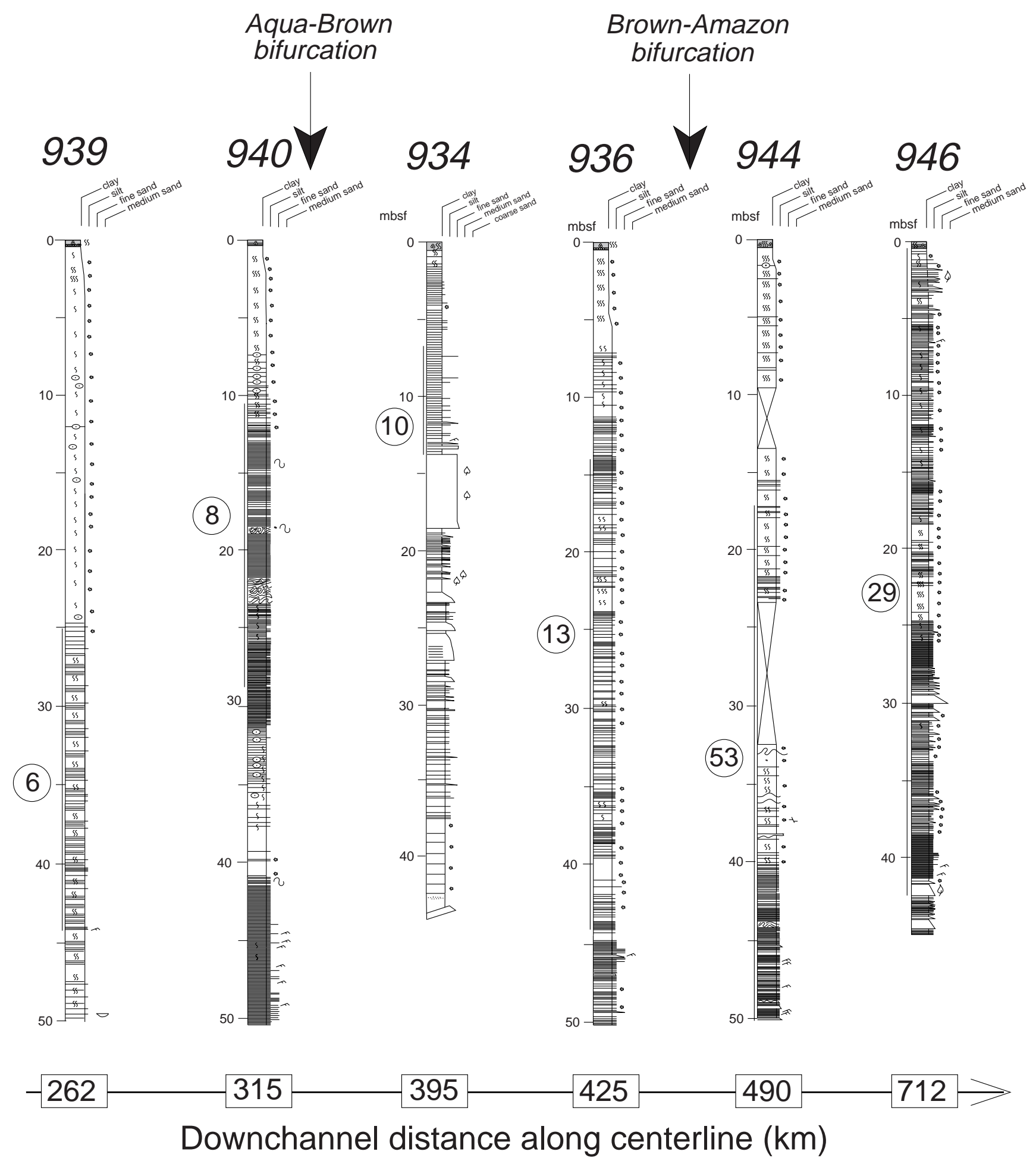

Figure 2. Graphic sedimentological columns for the Amazon Channel levee sites, showing grain-size variation (width of columns), bed thickness, and sedimentary structures; symbols and preparation of these columns are explained in Flood, Piper, Klaus, et al. (1995, p. 54). We only show here the part of the levee succession that was deposited after development of the Brown-Amazon bifurcation (i.e., during the most recent phase of channel activity). Bold lines and circled numbers beside each column show the stratigraphic range of samples discussed in this paper and the number of samples at each site. Site 939 is the most proximal, and Site 946 the most distal locality. 
mark, 1983), plus water entrainment thickening the current, produced a flow that had a narrow range of characteristics and was capable of persisting onto the lower fan.

\section{THEORETICAL CONSIDERATIONS}

In this paper, the word overspill is used to describe the process by which the upper part of a density current spills across confining levees. The word spillover is used as a noun or adjective to describe the materials that spill (or spilled) from the channel; that is, the deposits resulting from the overspill process. Theoretical models of turbidity currents require continuous flow thickening in the downflow direction because of water entrainment (Komar, 1973; Stacey and Bowen, 1988; Dade et al., 1994), but it is possible to envision an equilibrium between this tendency to thicken and the tendency of flows that exceed bankfull channel depth to spill across confining levees and into adjacent interchannel lows. This loss of suspended load might eventually deplete the flow of its excess density, but the fact that overspill takes place from the more dilute flow top counteracts this effect by leaving a more concentrated residual flow within the channel below the levee crests. As long as the turbidity current retains sufficient volume to regenerate its quasi-steady state properties after flow stripping (by seawater entrainment), then it will continue to advance down the meandering channel system. In theory, therefore, a single turbidity current could spill semicontinuously from the leveed channel as it moves down the fan, attaining a balance between overspill and water entrainment. In reality, the overspill is probably episodic, being concentrated at low points (saddles) in the levee crests such as those that have been imaged along the Amazon Channel (Pirmez, 1994).

All along the Amazon Channel, the gradient of the backside of the levee is steeper than the gradient along the nearby channel axis. The levee backside slopes, together with the adjacent channel talweg slopes, allow constraints to be imposed on the characteristics of the overspilling turbidity currents. The equation for velocity, $u$, of the body of a turbidity current with uniform density (Middleton, 1966) is

$$
u^{2}=\frac{8 g^{\prime}}{f_{o}+f_{j}} d \sin \alpha ; \quad g^{\prime}=\frac{\Delta \rho}{\rho+\Delta \rho} g
$$

where $g=980 \mathrm{~cm} / \mathrm{s}^{2}, d=$ flow depth, $\rho+\Delta \rho=$ seawater density plus density difference between seawater and the turbidity current, $f_{o}+f_{i}$ $=$ sum of basal and interfacial friction factors, and $\alpha=$ bottom slope. The velocity can remain approximately constant even during dramatic thinning of a current (e.g., during flow stripping), as long as $d \sin \alpha$ remains approximately constant.

Pirmez (1994, p. 154) gives examples of slopes of levee backsides of $3^{\circ}-5^{\circ}$ beside channels with centerline slopes of about $0.25^{\circ}-0.35^{\circ}$ and bankfull depths of about 50-70 m. Consider a channel depth of $60 \mathrm{~m}$ and a talweg slope of $0.3^{\circ}$, for which $d \sin \alpha=0.314 \mathrm{~m}$. On the adjacent levee backside, with slope of $4^{\circ}$, a spillover turbidity current with approximately the same velocity and therefore capability to retain its suspended load could have a thickness of only $4.5 \mathrm{~m}$. Greater flow thicknesses on the levee backside relative to bankfull flow depth in the channel, or greater backside slope relative to channel centerline slope, might lead to flow acceleration while traversing the backside of a levee, and nondeposition. The fact that levees of the Amazon Fan grow upward at high accumulation rates suggests that conditions for flow acceleration are not met, and, therefore, that the overspilling turbidity currents are relatively thin. Note that a lower concentration in the spillover flow than in the parent channelized flow, or higher friction factors for a thinner flow, would also favor deceleration on the backsides of the levees.

Unlike rivers, the cross-sectional area of the Amazon Channel decreases by a factor of about 30 from the upper through the middle fan
(Pirmez, 1994). Equation 1 indicates that, with all other variables constant, flow velocity will decrease with decreasing channel gradient, so that discharge within the channel must decrease by a larger factor, perhaps 50 to 100 , over the same distance. This sharp decrease in discharge through the channel cross-section is attributed directly to the loss of flow volume and sediment load by overbank spill.

Based on differential heights of left and right levees around channel bends with known curvature, Pirmez (1994) calculated flow velocities for turbidity currents experiencing bankfull flow, following Komar (1969). This procedure is equally valid for overspilling turbidity currents, so long as the average thickness of spillover is the same at the conjugate left and right banks. Velocity estimates depend on flow density as well as differential levee heights. Reasonable assumed solid concentrations of $0.6 \%$ and $2.5 \%$ were used by Pirmez (1994) to calculate velocities of 0.5 to $2.0 \mathrm{~m} / \mathrm{s}$, respectively, on the middle fan, decreasing to 0.5 to $1.5 \mathrm{~m} / \mathrm{s}$, respectively, on the lower fan.

\section{SAMPLING SITES AND SAMPLING STRATEGY}

Samples of spillover turbidites, formed mainly of silt and sand, were collected from the six levee sites. Depths over which samples were taken are marked on Figure 2. The number of samples taken at each site is different because some sites contained many more silt and sand turbidites than others. At sites where silt and sand turbidites are most numerous, sampling strategy included collecting several samples from single turbidites to evaluate grading patterns and paleocurrent swings during their deposition.

The initial aim of our sampling was to obtain samples from a single set of turbidites to be traced from site to site along the channel. This could only be achieved if the deposits of single overspill events could be recognized and correlated between sites. Were this to be achieved, then a quantitative assessment of downchannel evolution of single Pleistocene turbidity currents might have been possible. For example, Hesse (1995) was able to correlate single turbidites in piston and gravity cores for about $300 \mathrm{~km}$ along the right-hand levee of the low-sinuosity Northwest Atlantic Mid-Ocean Channel (NAMOC) in the Labrador Sea. Our sampling of the levees of the Amazon Channel was an attempt to apply the same procedure to the much more sinuous planform of this channel.

We were unable to correlate individual turbidites between the sites. One reason for this failure is the large number of superficially similar levee turbidites at each site (Fig. 2). Figure 3 shows for each Amazon Channel levee site, the surrounding bathymetry and channel shape from SeaBeam data, $3.5-\mathrm{kHz}$ echofacies recognized in nearsurface deposits from Lamont-Doherty Earth Observatory cruises, and selected $3.5-\mathrm{kHz}$ profiles. The complex distribution of echofacies in near-surface sediments suggests that the overspill process is complicated in detail, perhaps because of the complex behavior of turbidity currents negotiating tight curves along the meandering channel. Sites 936 and 944 are closest to one another $(65 \mathrm{~km}$ centerline distance), but they are on opposite sides of the channel. Sites 934 and 936 are closer, at $30 \mathrm{~km}$, but are again on opposite sides of the channel. Also, Site 934 is not a typical levee site (Fig. 3); it is in an abandoned meander loop that has been filled, since neck cutoff of the meander, by spillover deposits. Turbidity currents can more easily spill into the abandoned channel segment than over the higher adjacent levee, so that the spillover deposits at Site 934 are coarser grained and thicker bedded than at Site 936, hampering correlation.

Because correlations of single turbidites could not be accomplished, a program of sampling was developed to determine the general characteristics of the coarser spillover deposits from the Amazon Channel, to search for consistent trends in the texture of these levee turbidites along the channel, and to determine the paths taken by the overspilling turbidity currents on the backsides of the levees. 


\section{METHODS}

\section{Sampling and Sample Orientation}

Samples with volumes of $8 \mathrm{~cm}^{3}$ were collected from silt and sand turbidites using approximately cubic plastic containers with beveled edges designed for paleomagnetic studies. Two X-radiographs of each sample cube were obtained, one parallel to the front face of the cube and one parallel to the side of the cube. In general, bedding or lamination had no systematic dip in X-radiographs parallel to the front face of sample cubes, because the samples were taken in the center of the split-core face and parallel with any visible layering. However, many samples had a moderate to large dip from the front side to the back side of the cube (Fig. 4), visible in the side-view Xradiograph. This occurs because the core was split into two equal halves, so that the working half of the core contains sediment from the centerline to the margin of the core. The sample cube was therefore pressed into sediment on one side of the core, rather than in the middle of the core. In this marginal area, primary laminae tend to be curved downward because of drag along the core liner during penetration of the Advanced Piston Corer (APC). The apparent dips of laminae in both sets of X-radiographs were measured with a protractor, and these apparent dips were plotted on a stereonet to obtain true dip values, relative to geographic north derived from shipboard passthrough magnetometer data. These bedding dips were subsequently used to correct magnetic fabric data to a frame of reference defined by horizontal bedding, similar to modern seabed inclinations on the levees of $<5^{\circ}$.

Following laboratory analysis of samples from the six levee sites along the Amazon Channel, it became apparent that a particular type of silt-mud lamination $\left(\mathrm{T}_{d}\right.$ division of Bouma, 1962) characterizes some overspill turbidites (facies 3A and 4A of Piper and Deptuck, this volume). Particularly well-developed examples of this lamination (Fig. 5) were recovered from Site 931 in the levee of Channel 5 of Damuth et al. (1983b), to the east of the Amazon Channel; two additional samples were obtained from this site for comparison.

\section{Anisotropy of Magnetic Susceptibility}

The anisotropy of magnetic susceptibility (AMS; King and Rees, 1962) was measured on 108 samples from the six levee sites. The AMS technique measures the preferred magnetic-mineral orientation, or fabric, of elongated silt- to sand-sized magnetic grains (Hrouda, 1982). Rees (1965) demonstrated that the principle AMS eigenvector is commonly either parallel, or normal, to current direction.

The magnetic susceptibility $(\kappa)$ is defined as the dimensionless ratio of the intensity of the induced remanence $(J)$ in a sample to the intensity of the applied field $(H)$ (i.e., $\kappa=J / H)$. The bulk susceptibility of a sediment is a function of the concentration of the ferrimagnetic components (e.g., magnetite). This measurement also takes into account contributions from paramagnetic (e.g., hornblende) and diamagnetic (e.g., quartz) components. For any given mineral, the susceptibility is anisotropic and typically highest along the long axis. At room temperature, this anisotropy results primarily from two aspects of the mineral: (1) its chemistry, crystal structure, and size; and (2) its shape (O'Reilly, 1984).

The AMS measurements were performed using a Kappabridge KLY-2 susceptibility meter at the University of California, Santa Barbara. For these measurements, a special sample holder was fabricated. The paramagnetic effects of the plastic used in this study were typically 4 orders of magnitude weaker than the susceptibility of the samples. Nonetheless, the meter was configured to subtract the value of the sample holder from each measurement. The susceptibility of a sample is calculated as a second rank tensor defined by six values: three related to the direction of the eigenvectors and three related to the values of susceptibility along these axes. Thus, six measurements are required to define the principal susceptibility axes. However, for these analyses, we employed a redundant sampling scheme of 15 measurements to minimize the amount of error associated with each sample measurement. The three-dimensional shape of the measured susceptibility is that of an ellipsoid defined by three orthogonal axes $\left(k_{\text {maximum }}\left[k_{\text {max }}\right], k_{\text {intermediate }}\left[k_{\text {int }}\right]\right.$, and $\left.k_{\text {minimum }}\left[k_{\text {min }}\right]\right)$. It is the direction of the $k_{\max }$ axis that is used to constrain the paleocurrent direction. The magnitudes and directions of the principal susceptibility axes are given as the susceptibility of each axis corrected by the average measured susceptibility of the sample, and the relative orientation and dip of each axis.

By using the standard paleomagnetic bedding correction, the orientations of the principal axes of susceptibility were corrected for coring-induced bedding dip, determined from X-radiographs. The resulting values were geographically oriented by subtracting values of paleomagnetic declination from the orientation of the principal axis, giving what we call an AMS paleoflow alignment. Paleomagnetic declination was determined during the leg on the archive halves of the cores following alternating field demagnetization at $20 \mathrm{mT}$; this declination provides an estimate of true north. If paleomagnetic measurements were not performed at the same depth as a particular sample, a declination value was determined by linear interpolation between the bounding values. The paleomagnetic declination values are preferred to declination values measured on discrete samples because the shipboard values are smoothed over a larger depth interval, thereby minimizing the effects that both current transport (Shor et al., 1984) and geomagnetic secular variation can have on the declination. Although the pass-through remanent measurements may represent too short an interval of time at the high accumulation rates of the Amazon Fan to provide a good estimate of true north, we expect little deviation from true north at these low-latitude sites.

Alternatively, we could have based geographic orientation on the average value of paleomagnetic declination for the entire core section from which a sample was taken. In the discussion of results, we deal only with results corrected using shipboard paleomagnetic declination values for the same depths as the sample itself, although we also report the alternative average declination values and their standard deviations in the data table. Note that for the large majority of samples these two procedures do not give significantly different estimates of true north.

The foliation plane is perpendicular to the $k_{\min }$ axis and contains the $k_{\max }$ and $k_{\text {int }}$ axes. This foliation plane may dip at some small angle to the primary bedding plane if the magnetic grains are imbricated (Taira, 1989). Deviations from a subhorizontal orientation suggest that (1) the technique was unable to define the ellipsoid because the sample had a low susceptibility, (2) a primary current-generated fabric was not developed, or (3) a postdepositional fabric may have developed because of bioturbation, or diagenesis/authigenesis. We use the criteria of Shor et al. (1984) to accept or reject samples: (1) the inclination of the $k_{\min }$ axis must be $<15^{\circ}$ from the vertical; and (2) the calculated root-mean square error for each measurement must be $<10$, and (3) $k_{\text {max }}>k_{\text {int }}>>k_{\text {min }}$.

\section{Analysis of Grain Size and Sedimentary Structures}

Most of the silt and silty sand beds that were sampled are thinner than about $5 \mathrm{~cm}$ and have sharp bases and rapidly gradational tops. A few beds are thicker, the thickest being about $20 \mathrm{~cm}$. Although lamination was not noted in the shipboard description of most of these beds (they were commonly expanded by bedding-parallel gas voids), the X-radiographs show that $69 \%$ of the samples are parallel laminated and $4 \%$ are ripple cross-laminated. Lamination is enhanced in $\mathrm{X}$ radiographs by concentrations along some laminae of more dense heavy minerals or less dense organic material (e.g., plant fragments).

Some samples were taken from sediment characterized by 1 - to 2 mm-thick alternations of silt and mud, at the top of turbidites. This is 

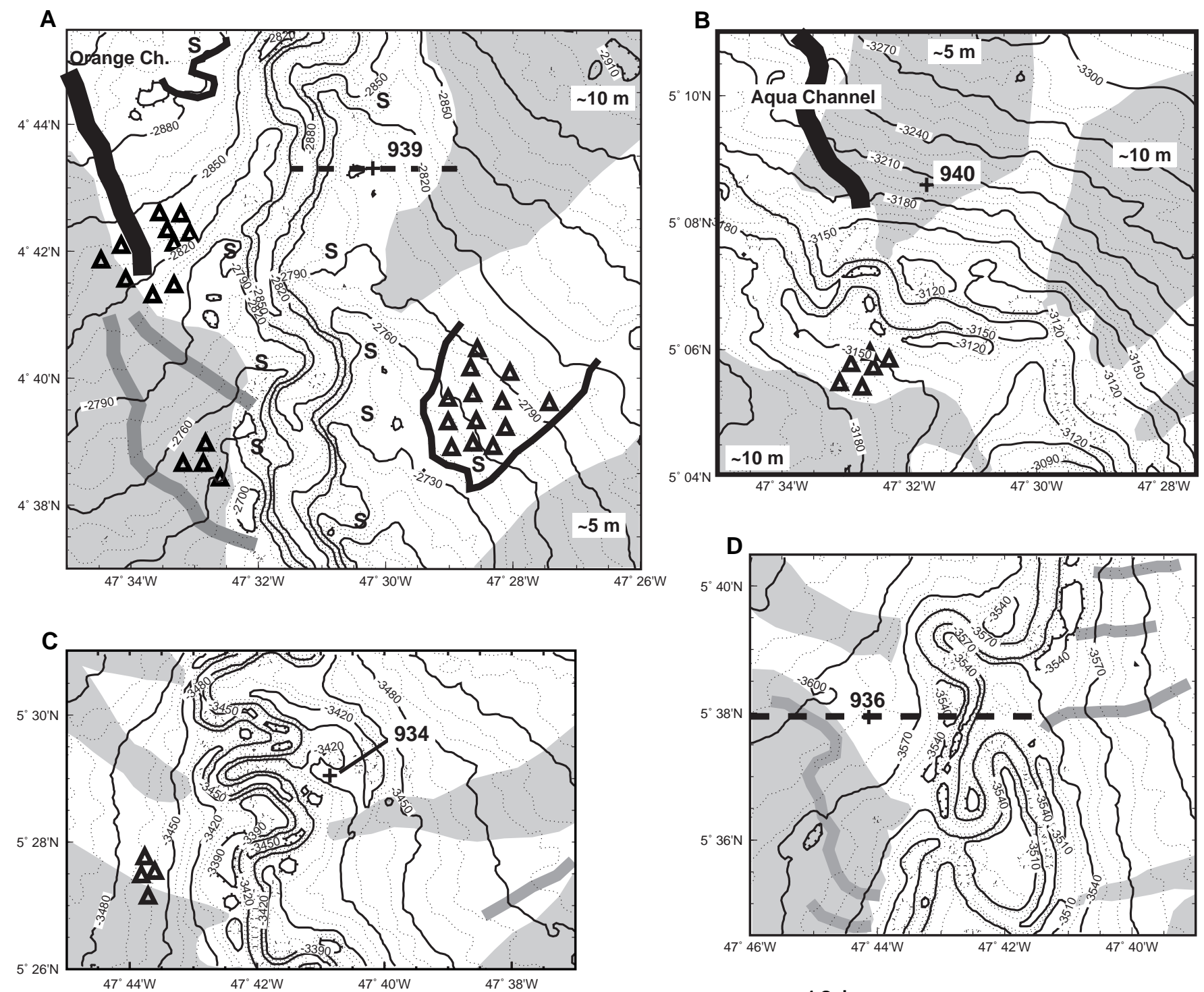

$10 \mathrm{~km}$
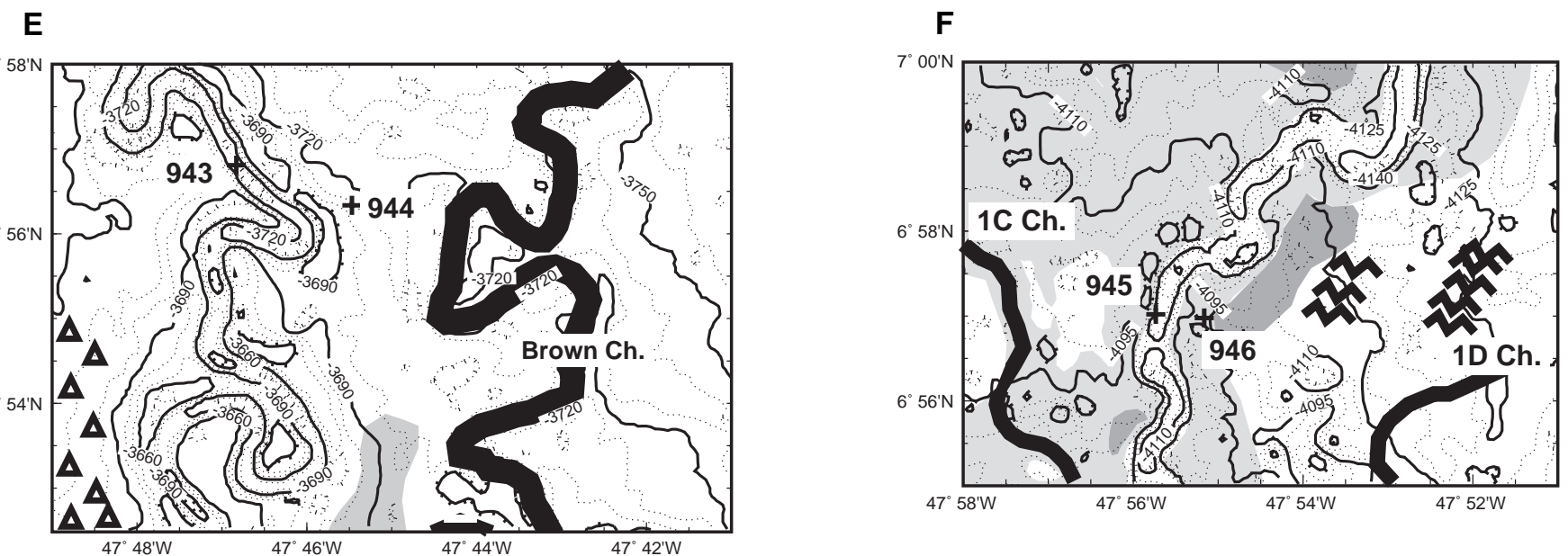

Figure 3. SeaBeam bathymetry (uncorrected meters, $v=1.5 \mathrm{~km} / \mathrm{s}$ ) and 3.5- kHz echofacies in the vicinity of six Leg 155 sites (numbered crosses) along the levees of the Amazon Channel. A. Vicinity of Site 939. B. Vicinity of Site 940. C. Vicinity of Site 934. D. Vicinity of Site 936. E. Vicinity of Site 944 . F. Vicinity of Site 946 : white = acoustically laminated returns on the $3.5-\mathrm{kHz}$ records, with the highest acoustic penetration; heavy stipple $=$ intermediate penetration with semi-prolonged or discontinuous reflections; light stipple $=$ the least acoustic penetration with prolonged acoustic returns; short zigzags = sediment waves; heavy black lines $=$ abandoned channels. 

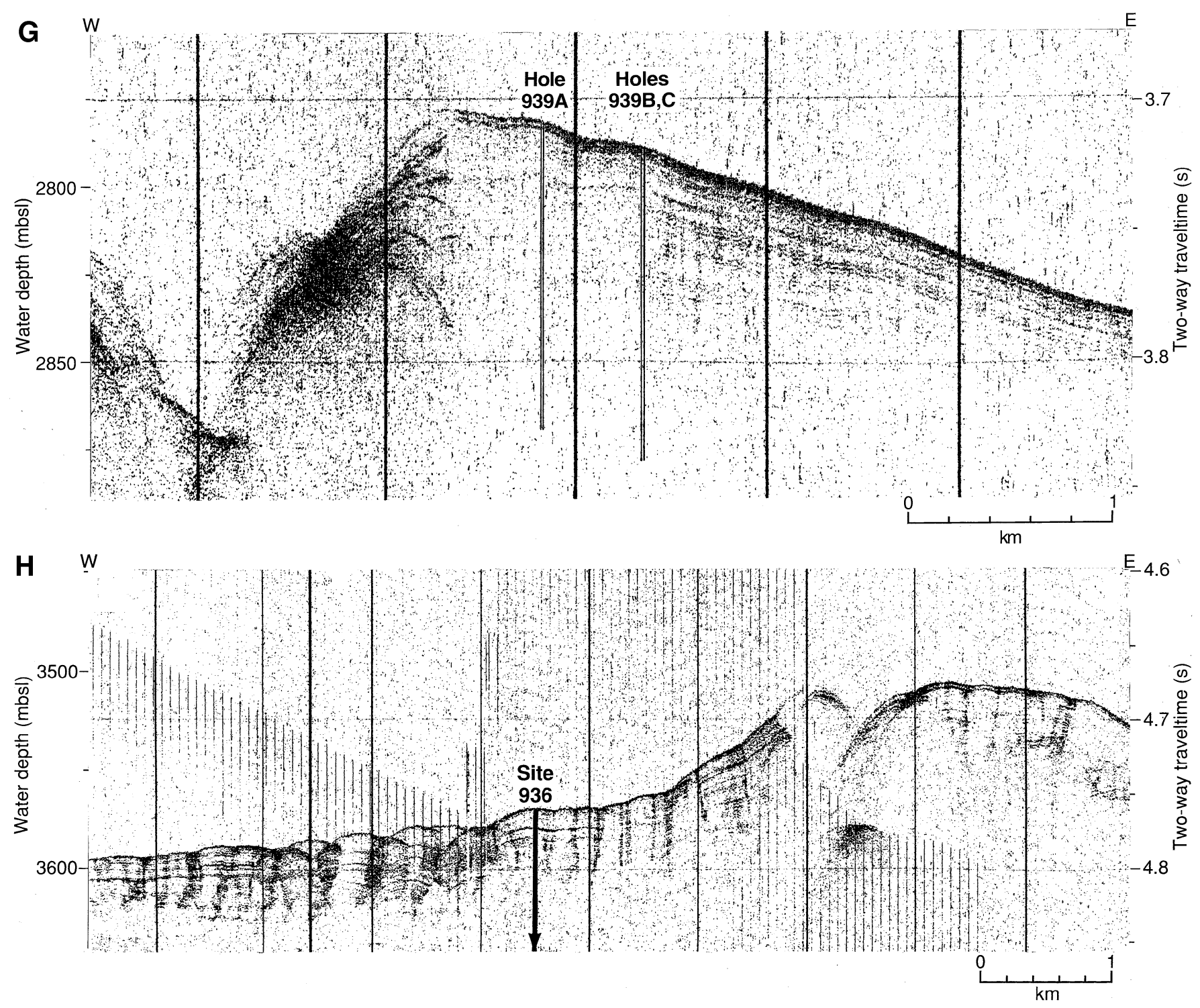

Figure 3 (continued). G. A 3.5-kHz profile from JOIDES Resolution through Site 939, and located on (A). H. A 3.5-kHz profile from JOIDES Resolution through Site 936 and located on (D). The site location maps were gridded and automatically contoured from SeaBeam data. In $(A)$ through $($ E), light stipple = thin $(0-10 \mathrm{~m})$ acoustically transparent to semitransparent lenses on the levee flanks, apparently sourced from localized saddles on the levee crest and interpreted as discrete areas of concentrated overbank deposits; heavy black lines = abandoned segments of the Amazon Channel system; bold triangles = hummocky topography; $\mathrm{S}$ = slump scars; heavy stippled lines = depressions on levee backsides, leading from saddles in levee crests that were probably pathways for enhanced overspill.

a type of $\mathrm{T}_{\mathrm{d}}$ division, described by Piper and Deptuck (this volume, their facies 3 and 4A). A thin slice of most of these silt-mud laminated samples, perpendicular to layering, was taken from one end of each cube, air dried, and subsequently impregnated with the low-viscosity biological resin LR White. Thin sections of the impregnated chip were prepared to investigate the character of the lamination. The remainder of each sample, after partial drying, was dissected using a sharp knife so as to obtain separate subsamples of silt and mud.

The grain size of all samples and subsamples was determined using a Micromeritics Sedigraph 5100 particle-size analyzer. Sediment, once removed from the plastic sample cubes, was placed in $15 \%$ peroxide solution to remove organic debris, then oven dried at $400^{\circ} \mathrm{C}$ in order for an accurate dry weight to be determined. After weighing, sediment was resuspended in a solution of $0.5 \%$ sodium hexametaphosphate (following Singer et al., 1988) during $15 \mathrm{~s}$ of insonification by a Braunsonic 1510 ultrasonic probe at $200 \mathrm{~W}$ power. Resuspended samples were wet-sieved through a $63-\mu \mathrm{m}$ sieve. The sand fraction $(>63 \mu \mathrm{m})$ was dried and weighed to determine its contribu-

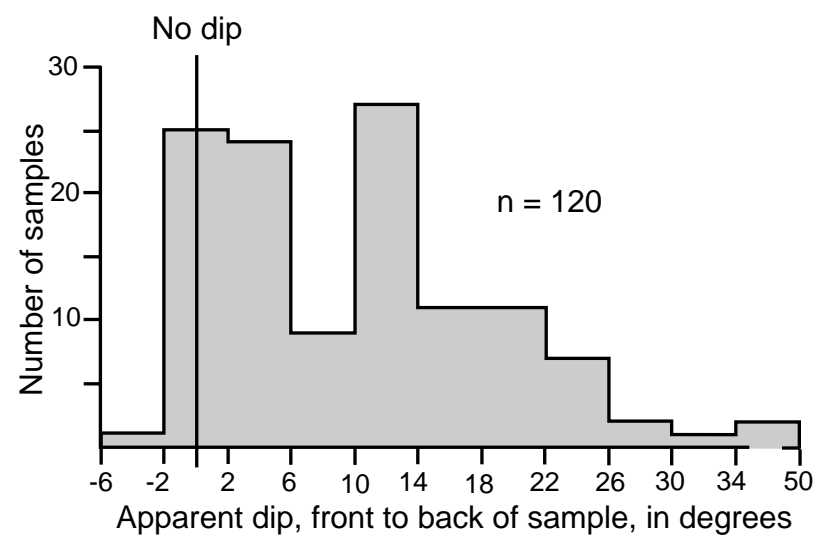

Figure 4. Distribution of apparent dips of primary flat lamination, from the front to the back of sample cubes, measured on X-radiographs. 
A

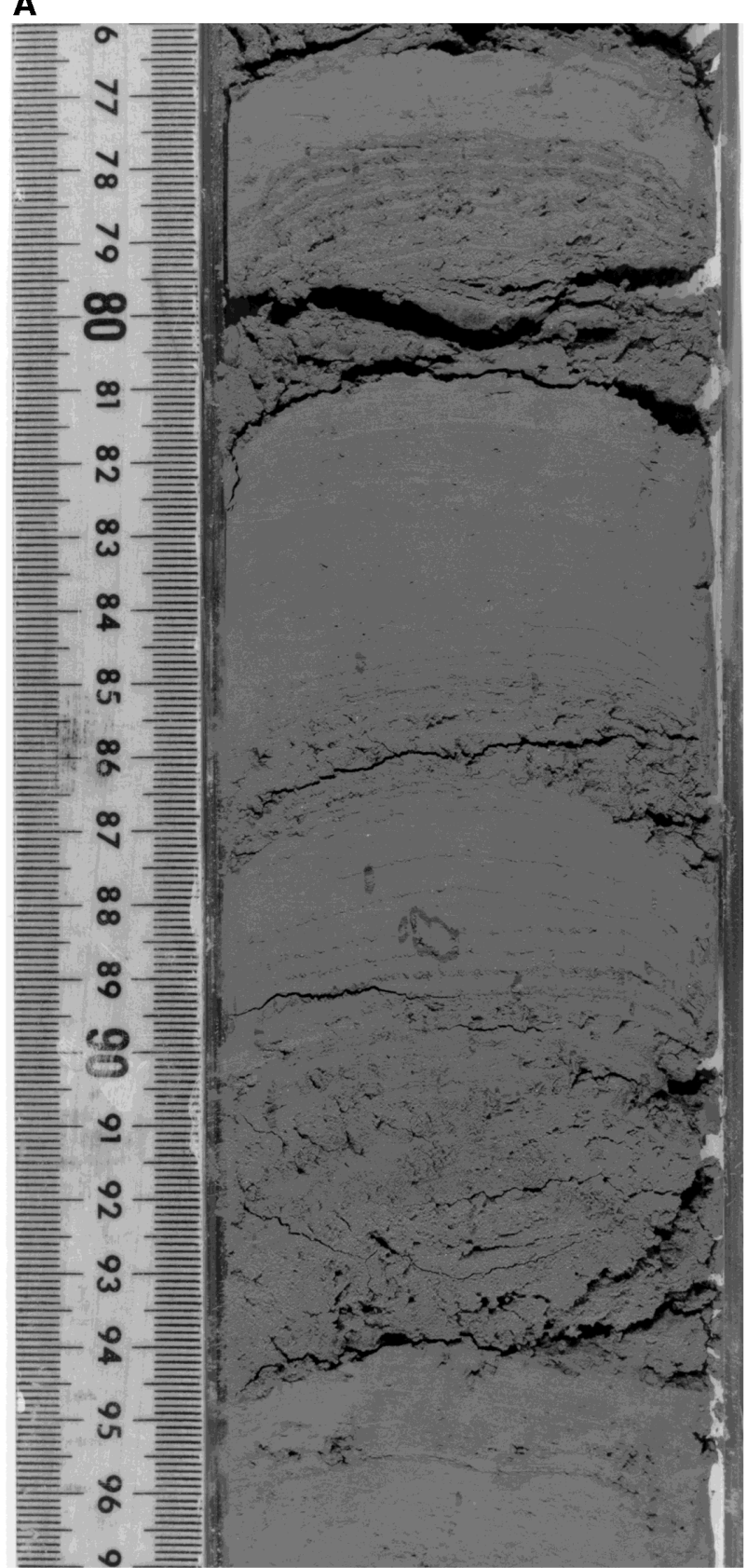

B

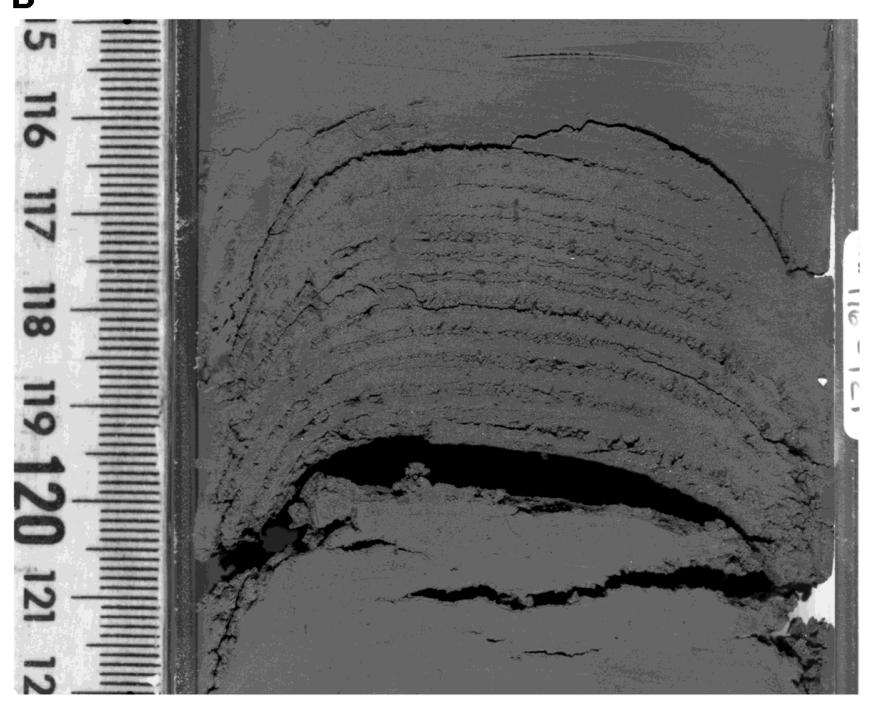

Figure 5. Examples of thick $T_{d}$ divisions in spillover turbidites from Site 931, levee of Channel 5, Amazon Fan. A. Three successive turbidites with thick siltmud laminae at their top (interval 155-931A-4H-2, 76-97 cm). B. Close-up of thick silt-mud laminae forming an entire spillover turbidite (interval 155-931B$4 \mathrm{H}-6,115-122 \mathrm{~cm})$.

tion to the total sample weight. The fine suspension was homogenized with a magnetic stirrer and diluted into the optimum concentration range for introduction to the Sedigraph. No particular sample concentration is required for Sedigraph analysis, although it is recommended that the sample reduce the radiation beam intensity, relative to background, by $13 \%-70 \%$. This is usually achieved with suspensions having $>5 \%$ volume concentration of solids. X-ray counts on a typical baseline solution of $0.5 \%$ sodium hexametaphosphate were about 75,000 counts/s during analysis of the Amazon Fan samples. Typical sediment suspensions ran at 45,000-65,000 counts/s.

Because the initial sample was wet-sieved at $63 \mu \mathrm{m}$, we were surprised that the first runs on the Sedigraph assigned part of the sediment to the size class $63-125 \mu \mathrm{m}$. The Sedigraph software bases its determination of size on known values of viscosity and density for the fluid, and on grain density (specified as a quartz density of 2.65 $\mathrm{g} / \mathrm{cm}^{3}$ for the first runs). However, Amazon Fan silts and sands contain 5\%-15\% heavy minerals (e.g., hornblende with a density of 3.0$3.4 \mathrm{~g} / \mathrm{cm}^{3}$, pyroxene with a density of $3.25-3.55 \mathrm{~g} / \mathrm{cm}^{3}$ ), so that the average grain density must be higher than $2.65 \mathrm{~g} / \mathrm{cm}^{3}$. Twelve unconsolidated silt samples for which grain density was determined for the Leg 155 Initial Reports (Flood, Piper, Klaus, et al., 1995) have a mean density of $2.786 \mathrm{~g} / \mathrm{cm}^{3}$, with a standard deviation of $0.05 \mathrm{~g} / \mathrm{cm}^{3}$. When all samples are replotted using an assumed grain density of $2.79 \mathrm{~g} / \mathrm{cm}^{3}$, reported weight percentages in the $63-125 \mu \mathrm{m}$ size class become insignificant.

The $>63-\mu \mathrm{m}$ fraction of samples that contain more than $10 \%$ sand was suspended in ethylene glycol and further analyzed over the range $350-31 \mu \mathrm{m}$. Both data sets (i.e., a $<63-\mu \mathrm{m}$ analysis, and either a 350- 
to $31-\mu \mathrm{m}$ analysis or the raw weight percent that is greater than $63 \mu \mathrm{m}$ for samples with $<10 \%$ sand) were combined in proportion to the results of wet sieving and plotted as a cumulative curve on probability paper, with grain size expressed in $\phi$ units (Krumbein, 1934; $\phi=-$ $\log _{2} D$, where $D$ is the grain diameter in millimeters).

Four small samples from silt laminae in $\mathrm{T}_{\mathrm{d}}$ divisions were spiked with $2 \mathrm{~g}$ of evenly sized quartz sand $(125-90 \mu \mathrm{m})$ to increase the sediment concentration. The weight percent attributed to the sand spike, having no overlap in size with the silt in the sample, was deleted from the data file before normalizing the silt component to $70 \%-85 \%$, so that the shape of its plot on probability paper is similar to the shape of plots for unspiked samples. Modification of the settling behavior of the fine particles by the presence of sand grains in the dilute suspensions is assumed negligible.

\section{AMS PALEOFLOW RESULTS}

Deposition from a unidirectional current can result in a statistical alignment of the long axes of the magnetic particles, primarily those in the silt-to-sand size range, parallel with the alignment of the associated nonmagnetic fraction (Hamilton and Rees, 1970). In silt and sand deposits, the average long-axis fabric may be either parallel or normal to the flow direction, less commonly at some intermediate angle. In tractional deposits beneath persistent bottom currents, Ledbetter and Ellwood (1980) reported flow-normal magnetic fabrics. Ellwood (1979) hypothesized that this type of fabric could form even if the magnetic grains were originally contained in larger floccules. Contrary to the interpretations of Ledbetter and Ellwood (1980), the strength of the magnetic alignment is not necessarily an indicator of the intensity of the flow (Flood et al., 1984).

For one turbidite, Ledbetter and Ellwood (1980) demonstrated flow-parallel alignments at the base and top, but only approximate flow-normal alignments in the middle of the bed. Taira and Scholle (1979) reported very weak flow-normal alignments in the $T_{a}$ divisions of 63 ancient turbidites, and much stronger flow-parallel alignments in divisions $\mathrm{T}_{\mathrm{b}}$ (138 determinations) and $\mathrm{T}_{\mathrm{c}}$ (64 determinations). Numerous optical studies of grain orientation in turbidites (summarized in Hiscott and Middleton, 1980) indicate flow-parallel grain alignments. Because $>70 \%$ of the silt to fine-sand samples from the levee turbidites of the Amazon Channel are from laminated or cross-laminated divisions $T_{b}$ and $T_{c}$, we provisionally interpret all of the measured magnetic fabrics as being parallel to the paleoflow direction.

Intuitively, the overspilling part of a turbidity current is expected to flow down the backside of the levee at some high angle to the channel axis. SeaBeam maps (Fig. 3) show alternating highs and saddles along levee crests, so that overspill might be confined to low points along the levees. From these points, overspilling currents might then spread laterally while flowing down the backside of the levee.

The samples collected for this study are mostly from depths of 10-45 mbsf (Fig. 2), so that the present-day seafloor morphology revealed by SeaBeam maps can only be taken as a crude approximation of the shape and position of the channel meanders and levees at the time of each overspill event. Although there is evidence for local meander cut-off and minor channel migration, the sinuous planform of the channel appears to change little over its lifetime, except downfan from avulsion sites (Pirmez, 1994). Therefore, we provisionally use the modern channel position as a guide to the evaluation of AMS paleoflow distributions at each site.

The $k_{\max }$ declination for a sample, after geographic reorientation and correction for bedding tilt, provides an estimate of paleoflow alignment but not paleoflow direction, because the true flow direction could be either the $k_{\max }$ declination or the $k_{\max }$ declination $\pm 180^{\circ}$. To select the best estimate of paleoflow direction, we used the SeaBeam bathymetry maps to subjectively decide which of these possibilities is the more likely paleoflow direction. Only these subjectively selected alternatives are presented with other AMS data in Table 1 (also on CD-ROM, back pocket, this volume), and are plotted as equal-area rose diagrams in Figure 6 . We believe that these rose diagrams represent the true range of paleoflow directions of turbidity currents that passed over each site on the levees of the Amazon Channel. As an alternative procedure, we could have used the dip of the magnetic foliation plane, a proxy for grain imbrication (Taira, 1989), to assign a unique paleoflow direction. However, this procedure is not dependable if the dip of the foliation plane is low, and is even less reliable for the Amazon Fan samples because of the fact that bedding planes were distorted during coring (Fig. 4). Of the 14 samples that did not contain lamination in X-radiographs, and for which no correction could be made for coring-induced tilt, four have $k_{\max }$ inclinations $>15^{\circ}$ and three have negative inclinations, including a value of $-14^{\circ}$.

One can compare the subjective and foliation-plane methods in Table 1 (also on CD-ROM, back pocket, this volume), where positive values of bedding-corrected $k_{\max }$ inclination correspond to samples for which the direction of grain imbrication determined from the dip of the foliation plane is consistent with our subjective assignment of a paleoflow direction. Negative values of $k_{\max }$ inclination mark situations where there is an apparent downflow imbrication of magnetic grains. The distribution of positive and negative values of $k_{\max }$ inclination is summarized in Figure 7.

\section{Site-by-Site AMS Paleoflow}

Site 939 is situated on the outside bend of a gentle meander where accentuated overspilling from the channel would not be expected. The levee crest in this area is high (about $90 \mathrm{~m}$ above the talweg) and relatively smooth. As a result, overspill of the coarser sand and silt load of turbidity currents is rare (Fig. 2). For samples of these uncommon events, AMS paleoflow ranges from north to east, consistent with the east-northeast-dipping backside gradient of the levee (Fig. $3)$.

Site 940 is located along a low-sinuosity reach of the channel (Fig. 3 ). At present, the levee crest stands about $60 \mathrm{~m}$ above the channel talweg. The levee crest is marked by local highs and saddles in this area; the saddles probably control the location of the highest discharge during spillover, and the pathways of the spillover turbidity currents. AMS paleoflow shows a spread of about $60^{\circ}$ toward the east-northeast, at an angle of more than $90^{\circ}$ from the local downchannel trend, but compatible with the north-northeast slope of the backside of the levee north of the site. We conclude that spillover preferentially takes place from the outer bend of the relatively tight meander SSW of Site 940, and not from the immediately adjacent channel segment, which is shielded from the site by a highpoint along the levee. As a result, overspilling turbidity currents have to travel eastward from the point where they exited the main channel to reach Site 940.

Site 934 is located in an abandoned (cut-off) meander loop that now has a floor about $55 \mathrm{~m}$ above the talweg of the Amazon Channel. This 55-m differential is partly the result of the filling of the segment after its abandonment, and partly the result of downcutting of the Amazon Channel in this area following downchannel avulsion that created a new distal segment of the Amazon Channel and abandoned the distal part of the Brown Channel (Note: near Site 934, the levees of the Amazon Channel were built by overspill during both the Amazon and Brown phases of channel development). The abandoned channel segment is like a hanging valley in the right levee of the Amazon Channel, and is therefore a preferred location for the upper parts of turbidity currents to be diverted out of the main channel (i.e., flow stripping). AMS paleoflow is to the east-southeast, consistent with the orientation of the entry to the abandoned meander loop.

Site 936 is the only left-bank levee site, and is in an area of complex channel meandering with highs and saddles in levee crests and with several possible spillover points both from the meander bend east of the site and from the bend immediately upfan (Fig. 3). The levee crest closest to the drill site currently stands about $70 \mathrm{~m}$ above the talweg floor. AMS paleoflow shows a wide range of values (Fig. 6) with a mean toward the west-northwest, in the direction of slope of the levee backside. Some of the more northerly AMS paleoflow di- 
Table 1. AMS data for Amazon Channel levee turbidites.

\begin{tabular}{|c|c|c|c|c|c|c|c|c|c|c|c|c|}
\hline & & & & & & & & & & & & sceptibili \\
\hline & & & eomagnet & tic direct & tions & & & & & $\mathrm{k}_{\max }$ & ientations & \\
\hline & Bedd & & Secti & & & Susceptibili & lity values : & and ratios & Mea & ured & Bedding & orrected \\
\hline interval $(\mathrm{cm})$ & strike & $\operatorname{dip}$ & mean & $\sigma$ & sample depth & $\mathrm{K}\left(10^{-6} \mathrm{SI}\right)$ & Foliation & Lineation & $D$ & $I$ & $D$ & $I$ \\
\hline 155-934B- & & & & & & & & & & & & \\
\hline $1 \mathrm{H}-5,0-2$ & 72 & 13 & 33.9 & 18.6 & 28.4 & 1119 & 1.013 & 1.046 & 109 & 7 & 81.6 & 0.7 \\
\hline $2 \mathrm{H}-4,83-85$ & 90 & 17 & 121.5 & $\begin{array}{r}10.0 \\
4.6\end{array}$ & 121.6 & 1193 & 1.012 & 1.071 & 78 & 8 & 139.4 & 11 \\
\hline $2 \mathrm{H}-4,89-91 *$ & 90 & 5 & 121.5 & $\begin{array}{l}4.0 \\
4.6\end{array}$ & 124.3 & 1384 & 1.021 & 1.054 & 88 & 20 & 145.8 & 20 \\
\hline $2 \mathrm{H}-4,91-93$ & 90 & 10 & 121.5 & 4.6 & 125.3 & 1379 & 1.004 & 1.029 & 55 & 4 & 110.7 & 10 \\
\hline $2 \mathrm{H}-5,47-49$ & 90 & 23 & 115.0 & 4.3 & 112.3 & 1117 & 1.004 & 1.061 & 75 & 10 & 147.7 & 15 \\
\hline $2 \mathrm{H}-5,49-51^{*}$ & 90 & 20 & 115.0 & 4.3 & 112.8 & 1201 & 1.014 & 1.022 & 82 & 5 & 151.2 & 7 \\
\hline $2 \mathrm{H}-5,70-72$ & 90 & 17 & 115.0 & 4.3 & 114.2 & 1038 & 1.010 & 1.067 & 218 & 21 & 100.8 & -7 \\
\hline $2 \mathrm{H}-5,77-79$ & 90 & 17 & 115.0 & 4.3 & 110.6 & 1504 & 1.013 & 1.052 & 258 & 7 & 146.4 & -3 \\
\hline $2 \mathrm{H}-5,83-85$ & 90 & 19 & 115.0 & 4.3 & $\begin{array}{l}109.0 \\
109.7\end{array}$ & 1129 & 1.014 & 1.050 & 76 & 3 & 148.3 & 7 \\
\hline $2 \mathrm{H}-5,88-90$ & 90 & 20 & 115.0 & 4.3 & 111.9 & 1068 & 1.015 & 1.042 & 242 & 2 & 131.1 & 7 \\
\hline $155-936 \mathrm{~A}-$ & & & & & & & & & & & & \\
\hline $2 \mathrm{H}-6,14-16^{*}$ & 90 & 18 & 339.7 & 3.8 & 339.5 & 1446 & 1.012 & 1.010 & 151 & 6 & 351.5 & 10 \\
\hline $2 \mathrm{H}-6,19-21$ & 135 & 14 & 339.7 & 3.8 & 342.1 & 1205 & 1.001 & 1.030 & 155 & 4 & 352.9 & 0.9 \\
\hline $2 \mathrm{H}-6,37-39$ & 60 & $\begin{array}{r}14 \\
9\end{array}$ & 339.7 & $\begin{array}{l}3.0 \\
3.8\end{array}$ & 341.9 & 689 & $\begin{array}{l}1.001 \\
1.010\end{array}$ & $\begin{array}{l}1.030 \\
1.050\end{array}$ & 107 & $\begin{array}{l}4 \\
5\end{array}$ & 305.1 & $\begin{array}{l}.9 \\
1.6\end{array}$ \\
\hline $2 \mathrm{H}-6,81-83$ & 90 & 24 & 339.7 & $\begin{array}{l}3.0 \\
3.8\end{array}$ & 339.8 & 967 & 1.018 & $\begin{array}{l}1.030 \\
1.026\end{array}$ & 275 & 3 & 293.2 & $5^{1.0}$ \\
\hline $3 \mathrm{H}-1,43-45$ & 69 & 16 & 246.4 & 3.4 & 246.3 & 671 & 1.005 & 1.038 & 110 & 4 & 223.7 & -7 \\
\hline $3 \mathrm{H}-5,74-76$ & 90 & 15 & 238.3 & 7.7 & 242.8 & 762 & 1.009 & 1.044 & 214 & 26 & 328.2 & 13 \\
\hline $4 \mathrm{H}-2,21-23^{*}$ & 65 & 21 & 342.4 & 10.4 & 346.8 & 795 & 1.012 & 1.027 & 260 & 25 & 262.2 & 29 \\
\hline $4 \mathrm{H}-4,73-75$ & 270 & 4 & 154.0 & $\begin{array}{r}4.4 \\
4.0\end{array}$ & $\begin{array}{l}339.7 \\
139.7\end{array}$ & 1030 & 1.013 & 1.076 & 263 & 5 & 303.3 & 5 \\
\hline $4 \mathrm{H}-4,75-77$ & 28 & 6 & $\begin{array}{l}134.0 \\
154.0\end{array}$ & $\begin{array}{l}4.0 \\
4.0\end{array}$ & 139.5 & 1855 & $\begin{array}{l}1.015 \\
1.000\end{array}$ & $\begin{array}{l}1.070 \\
1.089\end{array}$ & 214 & 16 & 252.5 & 17 \\
\hline $4 \mathrm{H}-6,44-46$ & 74 & 21 & 297.0 & $\begin{array}{l}4.0 \\
4.9\end{array}$ & 297.1 & 764 & 1.010 & $\begin{array}{l}1.089 \\
1.069\end{array}$ & $\begin{array}{l}214 \\
207\end{array}$ & 31 & 263.9 & 15 \\
\hline $5 \mathrm{H}-7,71-73$ & 52 & 13 & 179.4 & 5.7 & 185.6 & 980 & 1.006 & 1.052 & 97 & 4 & 271.4 & 5.2 \\
\hline $5 \mathrm{H}-7,82-84$ & 59 & 11 & 179.4 & 5.7 & 187.1 & 825 & 1.007 & 1.050 & 102 & 10 & 275.9 & -2 \\
\hline 155-939B- & & & & & & & & & & & & \\
\hline $4 \mathrm{H}-2,70-72$ & 90 & 20 & 243.8 & 14.7 & 262.5 & 3435 & 1.005 & 1.040 & 269 & 0 & 6.5 & 0.3 \\
\hline $4 \mathrm{H}-6,4-6$ & 90 & 20 & 243.4 & 2.2 & 249.5 & 738 & 1.005 & 1.065 & 161 & 26 & 93.5 & 7 \\
\hline $5 \mathrm{H}-6,77-79$ & 90 & 10 & 253.3 & 3.0 & 257.1 & 666 & 1.004 & 1.086 & 122 & 14 & 46.9 & 9 \\
\hline $6 \mathrm{H}-3,52-54$ & 90 & 5 & 329.3 & 5.3 & 337.7 & 796 & 1.004 & 1.063 & 10 & 4 & 32.3 & 9 \\
\hline $155-939 \mathrm{C}-$ & & & & & & & & & & & & \\
\hline $4 \mathrm{H}-3,128-130$ & 90 & 3 & 164.4 & 4.3 & 165.2 & 1103 & 1.009 & 1.076 & 244 & 10 & 78.8 & 9 \\
\hline $155-940 \mathrm{~A}-$ & & & & & & & & & & & & \\
\hline $2 \mathrm{H}-6,98-100$ & 60 & 13 & 237.3 & 2.7 & 234.9 & 906 & 1.004 & 1.053 & 257 & 1 & 21.1 & 5 \\
\hline $2 \mathrm{H}-7,25-27$ & 90 & 10 & 224.1 & 3.0 & 220.4 & 1970 & 1.007 & 1.053 & 259 & 1 & 38.6 & 0.9 \\
\hline $3 \mathrm{H}-6,11-13$ & 90 & $\begin{array}{r}10 \\
9\end{array}$ & 203.5 & $\begin{array}{l}.0 \\
6.5\end{array}$ & 205.1 & $\begin{array}{r}1970 \\
869\end{array}$ & $\begin{array}{l}1.001 \\
1.009\end{array}$ & $\begin{array}{l}1.035 \\
1.075\end{array}$ & 257 & $\begin{array}{l}1 \\
8\end{array}$ & $\begin{array}{l}3.0 \\
50.9\end{array}$ & 6 \\
\hline $3 \mathrm{H}-6,13-15$ & 90 & 5 & 203.5 & 6.5 & 204.8 & 1134 & 1.012 & 1.080 & 103 & 6 & 78.2 & -5 \\
\hline $3 \mathrm{H}-6,112-114$ & 90 & 0 & 203.5 & 6.5 & 204.2 & 672 & 1.011 & 1.052 & 100 & 1 & 75.8 & -1 \\
\hline $4 \mathrm{H}-5,35-38^{*}$ & 0 & 2 & 193.5 & 10.8 & 191.7 & 1291 & 1.045 & 1.039 & 132 & 18 & 120.3 & 17 \\
\hline $4 \mathrm{H}-5,127-130$ & 60 & 6 & 193.5 & 10.8 & 172.5 & 668 & 1.009 & 1.045 & 258 & 0 & 85.5 & -2 \\
\hline $155-944 \mathrm{~A}-$ & & & & & & & & & & & & \\
\hline $6 \mathrm{H}-4,23-25$ & 0 & 3 & 349.6 & 5.5 & 352.0 & 788 & 1.005 & 1.063 & 257 & 2 & 85.0 & 5 \\
\hline $6 \mathrm{H}-4,50-52$ & 90 & 0 & 349.6 & 5.5 & 354.8 & 1139 & 1.003 & 1.066 & 148 & 11 & 333.2 & 11 \\
\hline $6 \mathrm{H}-6,30-32$ & 54 & 4 & 335.3 & 5.0 & 328.9 & 826 & 1.009 & 1.093 & 204 & 14 & 54.1 & 12 \\
\hline $6 \mathrm{H}-6,32-34$ & 90 & 2 & 335.3 & 5.0 & 328.4 & 959 & 1.012 & 1.087 & 206 & 14 & 57.6 & 12 \\
\hline $6 \mathrm{H}-7,41-43$ & 90 & 0 & $181.5 \dagger$ & $94.0 \dagger$ & $\begin{array}{l}32.4 \\
122.4\end{array}$ & 1197 & 1.017 & $\begin{array}{l}1.0017 \\
1.027\end{array}$ & 274 & 14 & 331.6 & $\begin{array}{r}12 \\
-14\end{array}$ \\
\hline $6 \mathrm{H}-7,43-45$ & 45 & 8 & $181.5 \dagger$ & $94.0^{\dagger}$ & 119.7 & 1108 & 1.006 & 1.036 & 101 & 2 & 341.3 & -4.6 \\
\hline $6 \mathrm{H}-7,46-48$ & 90 & 30 & $181.5^{\dagger}$ & $94.0^{\dagger}$ & 119.3 & 1152 & 1.004 & 1.046 & 244 & 16 & 300.7 & -2 \\
\hline $6 \mathrm{H}-7,49-51$ & 90 & 0 & $181.5 \dagger$ & $94.0 \dagger$ & 120.7 & 1171 & 1.011 & 1.043 & 66 & 2 & 305.3 & 2 \\
\hline $6 \mathrm{H}-7,52-54$ & 90 & 8 & $181.5^{\dagger}$ & $94.0^{\dagger}$ & 132.0 & 1193 & 1.015 & 1.044 & 269 & 7 & 316.0 & -7 \\
\hline $6 \mathrm{H}-7,54-56$ & 0 & 2 & $181.5^{\dagger}$ & $94.0^{\dagger}$ & 139.6 & 1835 & 1.014 & 1.034 & 104 & 1 & 324.4 & -.9 \\
\hline $6 \mathrm{H}-7,57-59$ & 76 & 21 & $181.5 \dagger$ & $94.0 \dagger$ & $\begin{array}{l}156.1 \\
156.1\end{array}$ & 1931 & $\begin{array}{l}1.014 \\
1.011\end{array}$ & $\begin{array}{l}1.034 \\
1.042\end{array}$ & 173 & 17 & $\begin{array}{r}32.4 \\
16.9\end{array}$ & -4 \\
\hline 6H-CC, $13-15$ & 90 & 30 & $167.5 \dagger$ & $124.8^{\dagger}$ & 342.2 & 1166 & 1.008 & $\begin{array}{l}1.062 \\
1.062\end{array}$ & 282 & 3 & 116.8 & 9 \\
\hline 155-944B- & & & & & & & & & & & & \\
\hline $4 \mathrm{H}-4,90-92$ & 68 & 12 & 198.1 & 6.0 & 194.5 & 730 & 1.002 & 1.078 & 235 & 7 & 39.5 & 4 \\
\hline $4 \mathrm{H}-7,70-72$ & 40 & 8 & 188.8 & 2.4 & 187.2 & 611 & 1.004 & 1.061 & 174 & 9 & 345.8 & 3 \\
\hline $5 \mathrm{H}-3,49-51$ & 90 & $\begin{array}{r}0 \\
12\end{array}$ & $\begin{array}{l}100.0 \\
250.3\end{array}$ & 21.2 & 281.8 & $\begin{array}{l}011 \\
784\end{array}$ & $\begin{array}{l}1.004 \\
1.013\end{array}$ & $\begin{array}{l}1.001 \\
1.118\end{array}$ & 125 & 12 & $\begin{array}{r}24.0 \\
24.2\end{array}$ & 5 \\
\hline $5 \mathrm{H}-3,51-53$ & 80 & 23 & 250.3 & 21.2 & 277.8 & 946 & 1.012 & 1.065 & 121 & 17 & 26.2 & 1 \\
\hline $5 \mathrm{H}-3,54-56$ & 75 & 10 & 250.3 & 21.2 & 269.0 & 944 & 1.012 & 1.055 & 92 & 4 & 3.0 & 1 \\
\hline 155-944D- & & & & & & & & & & & & \\
\hline $3 \mathrm{H}-2,18-20$ & 90 & 6 & 198.0 & 3.7 & 194.6 & 837 & 1.011 & 1.042 & 66 & 1 & 51.4 & -3 \\
\hline $3 \mathrm{H}-2,58-60$ & 60 & 6 & 198.0 & 3.7 & 196.7 & 693 & 1.009 & 1.063 & 248 & 1 & 513 & 2 \\
\hline $3 \mathrm{H}-3,36-38$ & 90 & 4 & 190.3 & 15.1 & 191.3 & 826 & 1.005 & 1.047 & 252 & 1 & 60.7 & -.2 \\
\hline $3 \mathrm{H}-3,72-74$ & 270 & 2 & 190.3 & 15.1 & 181.8 & 734 & 1.018 & 1.050 & 81 & 0 & 79.2 & 0.3 \\
\hline $3 \mathrm{H}-3,75-76$ & 90 & 0 & 190.3 & 15.1 & 181.8 & 1155 & 1.020 & 1.057 & 262 & 8 & 80.2 & 8 \\
\hline $3 \mathrm{H}-3,103-105$ & 90 & 7 & 190.3 & 15.1 & 180.6 & 851 & 1.014 & 1.066 & 232 & 2 & 51.4 & -2.3 \\
\hline $3 \mathrm{H}-3,110-112$ & 45 & 9 & 190.3 & 15.1 & 183.3 & 791 & 1.007 & 1.063 & 76 & 1 & 72.7 & 3.6 \\
\hline $3 \mathrm{H}-3,121-123$ & 90 & 0 & 190.3 & 15.1 & $\begin{array}{l}18.3 \\
177.6\end{array}$ & 774 & $\begin{array}{l}1.001 \\
1.008\end{array}$ & $\begin{array}{l}1.003 \\
1.053\end{array}$ & $\begin{array}{l}10 \\
79\end{array}$ & 3 & 81.4 & -3.0 \\
\hline $3 \mathrm{H}-3,124-126$ & 90 & 5 & 190.3 & 15.1 & 172.8 & 722 & 1.006 & 1.077 & 259 & 1 & 86.2 & 0 \\
\hline $3 \mathrm{H}-3,126-128$ & 52 & 6 & 190.3 & 15.1 & $\begin{array}{l}16.0 \\
169.3\end{array}$ & 942 & $\begin{array}{l}1.005 \\
1.005\end{array}$ & 1.063 & 258 & $\begin{array}{l}1 \\
4\end{array}$ & $\begin{array}{l}0.2 \\
88.7\end{array}$ & 6 \\
\hline $3 \mathrm{H}-4,21-23$ & 69 & 11 & 173.6 & 7.3 & 175.4 & 818 & 1.002 & 1.070 & 225 & 8 & 48.6 & 3 \\
\hline $3 \mathrm{H}-4,45-47$ & 104 & 11 & 173.6 & 7.3 & 171.5 & 940 & 1.018 & 1.056 & 228 & 13 & 55.5 & 10 \\
\hline $3 \mathrm{H}-4,66-68$ & 103 & 10 & 173.6 & 7.3 & 164.8 & 808 & 1.003 & 1.085 & 230 & 9 & 64.2 & 1 \\
\hline $\begin{array}{l}3 \mathrm{H}-4,00-08 \\
3 \mathrm{H}-4,68-70\end{array}$ & $\begin{array}{r}103 \\
90\end{array}$ & $\begin{array}{l}10 \\
10\end{array}$ & $\begin{array}{l}173.0 \\
173.6\end{array}$ & $\begin{array}{l}1.3 \\
7.3\end{array}$ & $\begin{array}{l}104.8 \\
164.1\end{array}$ & $\begin{array}{r}808 \\
1018\end{array}$ & $\begin{array}{l}1.003 \\
1.011\end{array}$ & $\begin{array}{l}1.085 \\
1.065\end{array}$ & 233 & 17 & $\begin{array}{l}0.2 \\
66.9\end{array}$ & 11 \\
\hline $3 \mathrm{H}-4,73-75$ & 71 & 14 & 173.6 & 7.3 & 165 & 1400 & 1.023 & 1.059 & 234 & 14 & 65.5 & 10 \\
\hline $3 \mathrm{H}-4,101-103$ & 90 & 4 & 17 & 7.3 & 16 & 92 & 1.007 & 1.0 & 228 & 10 & 61.4 & 7 \\
\hline $3 \mathrm{H}-4,04-106^{*}$ & 90 & 0 & 173.6 & 7.3 & 167.0 & 1270 & 1.017 & 1.043 & 247 & 13 & 80.0 & 13 \\
\hline $3 \mathrm{H}-5,39-41$ & 90 & 5 & 149.8 & 7.8 & 158.7 & 917 & 1.001 & 1.091 & 257 & 5 & 98.3 & 4 \\
\hline $3 \mathrm{H}-5,41-43$ & 90 & 7 & 149.8 & 7.8 & 160.5 & 1108 & 1.012 & 1.071 & 271 & 2 & 110.5 & 2 \\
\hline $3 \mathrm{H}-5,63-65$ & 90 & 23 & $\begin{array}{l}149.8 \\
149.8\end{array}$ & $\begin{array}{l}1.8 \\
7.8\end{array}$ & $\begin{array}{l}100.3 \\
151.4\end{array}$ & 940 & $\begin{array}{l}1.012 \\
1.010\end{array}$ & $\begin{array}{l}1.071 \\
1.031\end{array}$ & 107 & 4 & 135.6 & 2.9 \\
\hline $3 \mathrm{H}-5,65-67$ & 90 & 22 & 149.8 & 7.8 & 152.3 & 892 & 1.013 & 1.034 & 281 & 4 & 126.7 & 8 \\
\hline $3 \mathrm{H}-5,70-72^{*}$ & 109 & 21 & $\begin{array}{l}149.8 \\
149.8\end{array}$ & $\begin{array}{l}1.0 \\
7.8\end{array}$ & 147.0 & $\begin{array}{l}892 \\
897\end{array}$ & 1.018 & $\begin{array}{l}1.034 \\
1.031\end{array}$ & $\begin{array}{l}201 \\
267\end{array}$ & $\begin{array}{r}4 \\
14\end{array}$ & 117.0 & $\begin{array}{l}0 \\
5\end{array}$ \\
\hline $3 \mathrm{H}-6,25-27$ & 122 & 7 & 141.4 & 3.9 & 144.5 & 849 & 1.008 & 1.067 & 254 & 4 & 109.5 & -1.2 \\
\hline
\end{tabular}


Table 1 (continued).

\begin{tabular}{|c|c|c|c|c|c|c|c|c|c|c|c|c|c|c|c|c|}
\hline \multirow{4}{*}{$\begin{array}{l}\text { Core, section } \\
\text { interval }(\mathrm{cm})\end{array}$} & \multirow{2}{*}{\multicolumn{5}{|c|}{ Paleomagnetic directions }} & \multirow{3}{*}{\multicolumn{3}{|c|}{ Susceptibility values and ratios }} & \multicolumn{8}{|c|}{ Susceptibility orientations } \\
\hline & & & & & & & & & \multicolumn{4}{|c|}{$\mathrm{k}_{\max }$ orientations } & \multicolumn{4}{|c|}{$\mathrm{k}_{\min }$ orientations } \\
\hline & \multicolumn{2}{|c|}{ Bedding } & \multicolumn{2}{|c|}{ Section } & \multirow{2}{*}{$\begin{array}{c}\text { Value at } \\
\text { sample depth }\end{array}$} & & & & \multicolumn{2}{|c|}{ Measured } & \multicolumn{2}{|c|}{ Bedding corrected } & \multicolumn{2}{|c|}{ Measured } & \multicolumn{2}{|c|}{ Bedding corrected } \\
\hline & strike & $\frac{\operatorname{dip}}{}$ & mean & $\sigma$ & & $\mathrm{K}\left(10^{-6} \mathrm{SI}\right)$ & Foliation & Lineation & $D$ & $I$ & $D$ & $I$ & $D$ & $I$ & $D$ & $I$ \\
\hline $4 \mathrm{H}-3,63-65$ & 90 & 13 & 111.2 & 4.1 & 115.0 & 875 & 1.009 & 1.038 & 93 & 2 & 338.0 & 1 & 355 & 78 & 225 & 89 \\
\hline $4 \mathrm{H}-3,65-67 *$ & 90 & 15 & 111.2 & 4.1 & $\begin{array}{l}115.9 \\
116.9\end{array}$ & 1030 & 1.004 & 1.020 & 117 & 24 & $\begin{array}{r}5.0 \\
5.1\end{array}$ & 17 & 353 & 52 & 349 & 67 \\
\hline $4 \mathrm{H}-5,28-30$ & 90 & 10 & $\begin{array}{r}111.2 \\
85.6\end{array}$ & $\begin{array}{l}4.1 \\
3.4\end{array}$ & $\begin{array}{r}10.9 \\
86.6\end{array}$ & 834 & $\begin{array}{l}1.004 \\
1.005\end{array}$ & $\begin{array}{l}1.020 \\
1.078\end{array}$ & 275 & $\begin{array}{r}24 \\
2\end{array}$ & $\begin{array}{l}5.1 \\
8.4\end{array}$ & $\begin{array}{l}11 \\
-3\end{array}$ & $\begin{array}{r}353 \\
11\end{array}$ & 73 & 26 & $\begin{array}{l}01 \\
83\end{array}$ \\
\hline $4 \mathrm{H}-5,52-54$ & 143 & 6 & 85.6 & 3.4 & 89.6 & 753 & 1.009 & 1.081 & 279 & 5 & 9.4 & -1 & 29 & 77 & 11 & 82 \\
\hline $4 \mathrm{H}-6,36-38$ & 113 & 11 & 68.1 & 5.0 & 70.2 & 539 & 1.002 & 1.108 & 135 & 7 & 65.8 & 3 & 20 & 74 & 14 & $\begin{array}{l}02 \\
85\end{array}$ \\
\hline $4 \mathrm{H}-6,38-40$ & 90 & 26 & 68.1 & 5.0 & 70.6 & 959 & 1.006 & 1.086 & 126 & 12 & 57.4 & -3.7 & 3 & 68 & 164 & 86 \\
\hline $4 \mathrm{H}-6,40-42$ & 90 & 11 & 68.1 & 5.0 & 70.8 & 1053 & 1.004 & 1.088 & 110 & 8 & 40.2 & 4 & 346 & 76 & 308 & 86 \\
\hline $5 \mathrm{H}-7,56-58$ & 113 & 17 & $\begin{array}{r}0.1 \\
168.7\end{array}$ & 5.0 & 168.5 & 782 & $\begin{array}{l}1.008 \\
1.008\end{array}$ & $\begin{array}{l}1.000 \\
1.081\end{array}$ & 246 & $\begin{array}{l}0 \\
16\end{array}$ & 75.5 & $\begin{array}{l}4 \\
3\end{array}$ & $\begin{array}{r}340 \\
20\end{array}$ & 67 & $\begin{array}{r}00 \\
12\end{array}$ & $\begin{array}{l}00 \\
84\end{array}$ \\
\hline $5 \mathrm{H}-7,60-62$ & 113 & 27 & $\begin{array}{l}108.1 \\
168.7\end{array}$ & $\begin{array}{l}5.0 \\
5.0\end{array}$ & $\begin{array}{l}178.5 \\
171.7\end{array}$ & 1166 & 1.015 & $\begin{array}{l}1.081 \\
1.038\end{array}$ & $\begin{array}{l}240 \\
266\end{array}$ & $\begin{array}{l}10 \\
18\end{array}$ & 89.3 & $\begin{array}{l}3 \\
5\end{array}$ & 19 & $\begin{array}{l}0 / 1 \\
51\end{array}$ & 11 & $\begin{array}{l}84 \\
78\end{array}$ \\
\hline $5 \mathrm{H}-7,79-81^{*}$ & 90 & 0 & $\begin{array}{l}108.1 \\
168.7\end{array}$ & $\begin{array}{l}.0 \\
5.0\end{array}$ & $\begin{array}{l}11.1 \\
159.3\end{array}$ & $\begin{array}{l}100 \\
855\end{array}$ & 1.011 & $\begin{array}{l}1.030 \\
1.037\end{array}$ & 250 & $\begin{array}{l}10 \\
30\end{array}$ & $\begin{array}{l}89.3 \\
90.7\end{array}$ & 30 & 12 & 42 & 12 & 42 \\
\hline $5 \mathrm{H}-7,85-87$ & 90 & 40 & 168.7 & 5.0 & 162.4 & 1036 & 1.006 & 1.051 & 231 & 22 & $\begin{array}{l}63.6 \\
63.6\end{array}$ & -5 & 358 & 56 & 191 & 84 \\
\hline \multicolumn{17}{|l|}{$155-946 \mathrm{~A}-$} \\
\hline $1 \mathrm{H}-2,23-25$ & 90 & 0 & 20.6 & 6.1 & 14.6 & 1171 & 1.011 & 1.035 & 253 & 3 & 58.4 & 3 & 354 & 74 & 354 & 74 \\
\hline $1 \mathrm{H}-2,29-31$ & 145 & 3 & $\begin{array}{l}20.0 \\
20.6\end{array}$ & $\begin{array}{l}0.1 \\
6.1\end{array}$ & $\begin{array}{l}14.0 \\
17.2\end{array}$ & 1487 & 1.019 & 1.016 & 271 & 35 & $\begin{array}{l}38.4 \\
73.9\end{array}$ & 13 & $\begin{array}{l}354 \\
125\end{array}$ & 72 & $\begin{array}{l}354 \\
134\end{array}$ & 73 \\
\hline $1 \mathrm{H}-2,35-37$ & 56 & 6 & 20.6 & 6.1 & 16.7 & 1300 & 1.009 & 1.029 & 254 & 6 & 56.3 & 8 & 26 & 81 & 67 & 82 \\
\hline $1 \mathrm{H}-2,78-80^{*}$ & 78 & 21 & 20.6 & 6.1 & 19.2 & 1442 & 1.011 & 1.016 & 261 & 6 & 59.8 & 7 & 359 & 50 & $\begin{array}{r}01 \\
9\end{array}$ & $\begin{array}{l}02 \\
70\end{array}$ \\
\hline $1 \mathrm{H}-2,83-85$ & 123 & 8 & 20.6 & 6.1 & 23.3 & 1405 & 1.006 & 1.020 & 258 & 10 & 53.7 & 4 & 67 & 80 & 120 & 84 \\
\hline $1 \mathrm{H}-2,88-91$ & 90 & 17 & 20.6 & 6.1 & 24.1 & 1496 & 1.005 & 1.021 & 94 & 5 & 70.9 & -4 & 353 & 67 & 335 & 84 \\
\hline $1 \mathrm{H}-2,138-140$ & 100 & 10 & 20.6 & $\begin{array}{l}0.1 \\
6.1\end{array}$ & 30.3 & 1460 & 1.008 & 1.044 & $\begin{array}{r}74 \\
269\end{array}$ & 4 & $\begin{array}{l}57.7 \\
57.9\end{array}$ & $\begin{array}{r}-4 \\
2\end{array}$ & 15 & 77 & 31 & $\begin{array}{l}84 \\
87\end{array}$ \\
\hline $1 \mathrm{H}-2,141-143$ & $\begin{array}{r}100 \\
90\end{array}$ & $\begin{array}{l}10 \\
18\end{array}$ & $\begin{array}{l}20.6 \\
20.6\end{array}$ & $\begin{array}{l}0.1 \\
6.1\end{array}$ & 31.5 & $\begin{array}{l}1400 \\
1634\end{array}$ & $\begin{array}{l}1.008 \\
1.012\end{array}$ & $\begin{array}{l}1.044 \\
1.033\end{array}$ & $\begin{array}{l}209 \\
272\end{array}$ & $\begin{array}{l}4 \\
1\end{array}$ & 60.5 & 2 & $\begin{array}{r}15 \\
5\end{array}$ & 72 & $\begin{array}{l}31 \\
92\end{array}$ & $\begin{array}{l}81 \\
88\end{array}$ \\
\hline $1 \mathrm{H}-2,145-148$ & 90 & 13 & 20.6 & 6.1 & 27.5 & 1749 & 1.010 & 1.024 & 279 & 3 & 70.5 & 5 & 14 & 65 & 28 & 77 \\
\hline $1 \mathrm{H}-3,1-3$ & 90 & 13 & 18.2 & 5.9 & 15.9 & 1655 & 1.003 & 1.025 & 98 & 5 & 83.1 & -3 & 343 & 78 & 247 & 86 \\
\hline $1 \mathrm{H}-5,48-50$ & 90 & 10 & 11.5 & 6.7 & 11.8 & 1106 & 1.011 & 1.053 & 120 & 10 & 109.2 & -5 & 1 & 70 & 2 & 80 \\
\hline $1 \mathrm{H}-5,52-54$ & 90 & 12 & 11.5 & 6.7 & 11.6 & 1665 & 1.005 & 1.057 & 139 & 18 & 129.4 & -9 & 4 & 65 & 8 & 77 \\
\hline $2 \mathrm{H}-2,74-76$ & 90 & 0 & 328.8 & 6.3 & 326.2 & 1138 & 1.016 & 1.056 & 261 & 4 & 114.8 & 4 & 41 & 85 & 41 & 85 \\
\hline $\begin{array}{l}2 \mathrm{H}-2,74-10 \\
2 \mathrm{H}-2,76-79\end{array}$ & $\begin{array}{l}90 \\
90\end{array}$ & $\begin{array}{l}0 \\
0\end{array}$ & $\begin{array}{l}328.8 \\
328.8\end{array}$ & $\begin{array}{l}0.3 \\
6.3\end{array}$ & $\begin{array}{l}320.2 \\
327.0\end{array}$ & $\begin{array}{l}1138 \\
1129\end{array}$ & $\begin{array}{l}1.010 \\
1.008\end{array}$ & $\begin{array}{l}1.056 \\
1.035\end{array}$ & $\begin{array}{l}201 \\
248\end{array}$ & $\begin{array}{l}4 \\
3\end{array}$ & $\begin{array}{l}114.8 \\
101.0\end{array}$ & $\begin{array}{l}4 \\
3\end{array}$ & $\begin{array}{r}41 \\
113\end{array}$ & $\begin{array}{l}85 \\
86\end{array}$ & $\begin{array}{r}41 \\
113\end{array}$ & $\begin{array}{l}85 \\
86\end{array}$ \\
\hline $2 \mathrm{H}-2,79-81$ & 90 & 3 & 328.8 & 6.3 & 327.9 & 988 & 1.011 & 1.042 & 260 & 12 & 111.1 & 11 & 53 & 76 & 64 & 78 \\
\hline $2 \mathrm{H}-4,8-10$ & 90 & 5 & 344.0 & 4.4 & 339.5 & 1002 & 1.010 & 1.045 & 277 & 0 & 117.5 & 0.6 & 9 & 75 & $\begin{array}{l}04 \\
13\end{array}$ & $\begin{array}{l}10 \\
80\end{array}$ \\
\hline $2 \mathrm{H}-4,12-15$ & 90 & 23 & 344.0 & 4.4 & 341.5 & 1005 & 1.004 & 1.043 & 256 & 1 & 95.5 & -4.5 & 348 & 71 & 222 & 84 \\
\hline $2 \mathrm{H}-4,17-19$ & 90 & 15 & 344.0 & 4.4 & 336.7 & 826 & 1.004 & 1.024 & 228 & 12 & 70.3 & 2 & 360 & 72 & 360 & 87 \\
\hline $4 \mathrm{H}-2,50-52^{*}$ & & 16 & 127.5 & $\begin{array}{l}.4 \\
6.0\end{array}$ & 120.0 & $\begin{array}{r}020 \\
1238\end{array}$ & 1.017 & $\begin{array}{l}1.024 \\
1.015\end{array}$ & $\begin{array}{r}20 \\
84\end{array}$ & 13 & 144.0 & 3 & 337 & 54 & -0 & $\begin{array}{l}01 \\
57\end{array}$ \\
\hline $4 \mathrm{H}-3,39-41^{*}$ & 0 & $\begin{array}{r}10 \\
5\end{array}$ & 117.5 & $\begin{array}{r}0.0 \\
27.2\end{array}$ & $\begin{array}{l}130.0 \\
131.2\end{array}$ & 1228 & $\begin{array}{l}1.017 \\
1.006\end{array}$ & $\begin{array}{l}1.015 \\
1.007\end{array}$ & $\begin{array}{l}84 \\
95\end{array}$ & $\begin{array}{l}13 \\
14\end{array}$ & $\begin{array}{l}144.0 \\
143.8\end{array}$ & $\begin{array}{r}3 \\
-9\end{array}$ & $\begin{array}{r}331 \\
1\end{array}$ & $\begin{array}{l}54 \\
14\end{array}$ & $\begin{array}{r}-0 \\
2\end{array}$ & $\begin{array}{l}5 l \\
14\end{array}$ \\
\hline $4 \mathrm{H}-3,96-98^{*}$ & 90 & 0 & 117.5 & 27.2 & 127.5 & 1212 & 1.009 & 1.004 & 245 & 53 & 117.5 & 53 & 354 & 14 & 354 & 14 \\
\hline $4 \mathrm{H}-4,61-63^{*}$ & 59 & 11 & 121.3 & 10.1 & 125.1 & 1016 & 1.010 & 1.015 & 257 & 10 & 129.9 & 13 & $\begin{array}{r}304 \\
4\end{array}$ & $\begin{array}{l}14 \\
58\end{array}$ & $\begin{array}{r}18 \\
18\end{array}$ & $\begin{array}{l}14 \\
66\end{array}$ \\
\hline $4 \mathrm{H}-5,48-50$ & 90 & 3 & 121.9 & 11.2 & 118.0 & 1267 & 1.000 & 1.055 & 268 & 3 & 150.0 & 3 & 139 & 85 & 154 & 83 \\
\hline $5 \mathrm{H}-1,45-47 *$ & 90 & 10 & 318.8 & 13.5 & 317.3 & 997 & 1.010 & 1.001 & 286 & 10 & 146.7 & -13 & 20 & 22 & 22 & 31 \\
\hline $5 \mathrm{H}-1,51-53^{*}$ & 90 & 0 & $\begin{array}{l}31.0 \\
318.8\end{array}$ & 13.5 & 294.5 & 990 & 1.012 & $\begin{array}{l}1.001 \\
1.038\end{array}$ & $\begin{array}{l}200 \\
101\end{array}$ & 16 & $\begin{array}{l}140.1 \\
166.5\end{array}$ & $\begin{array}{r}-13 \\
16\end{array}$ & 336 & 63 & 336 & 63 \\
\hline $5 \mathrm{H}-1,55-58^{*}$ & 90 & $\begin{array}{c}0 \\
17\end{array}$ & $\begin{array}{l}318.8 \\
318.8\end{array}$ & $\begin{array}{l}13.5 \\
13.5\end{array}$ & $\begin{array}{l}294.3 \\
295.9\end{array}$ & $\begin{array}{l}990 \\
1116\end{array}$ & $\begin{array}{l}1.012 \\
1.003\end{array}$ & $\begin{array}{l}1.038 \\
1.019\end{array}$ & $\begin{array}{l}101 \\
237\end{array}$ & $\begin{array}{r}10 \\
1\end{array}$ & $\begin{array}{l}100.3 \\
122.1\end{array}$ & $\begin{array}{r}10 \\
8\end{array}$ & $\begin{array}{l}330 \\
329\end{array}$ & $\begin{array}{l}03 \\
48\end{array}$ & $\begin{array}{l}330 \\
314\end{array}$ & $\begin{array}{l}03 \\
61\end{array}$ \\
\hline $5 \mathrm{H}-1,58-60$ & 90 & 13 & 318.8 & 13.5 & 312.9 & 1186 & 1.005 & 1.042 & 67 & 1 & 115.1 & 6 & 334 & $\begin{array}{l}40 \\
68\end{array}$ & 306 & 78 \\
\hline $5 \mathrm{H}-2,64-66$ & 30 & $\begin{array}{r}15 \\
8\end{array}$ & 283.6 & 3.4 & 277.2 & $\begin{array}{r}1100 \\
864\end{array}$ & 1.003 & 1.1 & 56 & 1 & 138.8 & -2.5 & 322 & $\begin{array}{l}00 \\
82\end{array}$ & 41 & 87 \\
\hline $5 \mathrm{H}-2,69-71$ & 90 & 15 & 283.6 & 3.4 & 279.7 & 1121 & 1.011 & 1.090 & 208 & 9 & 108.3 & 4.3 & 338 & 77 & 239 & 84 \\
\hline $5 \mathrm{H}-5,02-104 *$ & 90 & 0 & 270.2 & 19.3 & 200.0 & 1053 & 1.008 & 1.013 & 266 & 36 & 66.0 & 36 & 9 & 17 & 9 & 17 \\
\hline
\end{tabular}

Notes: The bedding dip is the largest angle, measured downward, between the bedding plane and a plane normal to the central axis of the core. Bedding strike and uncorrected declinations are measured within this second plane with $0^{\circ}$ defined to be normal to and outward from the split face of the working half of the core and positive angles increasing clockwise from $0^{\circ}$ to $360^{\circ}$ for an observer looking down the central axis of the core. By convention, bedding dip is normal to, and to the right of, the reported strike direction. $D=$ declination; $I=$ inclination. $*=$ samples rejected according to the criteria of Shor et al. (1984). $\dagger=$ anomalous and unreliable section averages resulting from paleomagnetic measurement problems.

This table also appears on CD-ROM.

rections may record deposition from turbidity currents that spilled out of the Amazon Channel at the outside bend of the meander upfan from the drill site, or they may be uncommon flow-normal alignments of the type described by Ledbetter and Ellwood (1980).

Site 944 is just downfan from a particularly sharp bend in the Amazon Channel (Fig. 3). The slope on the backside of the levee is to the northeast, consistent with the strongest mode in the AMS paleoflow distribution (Fig. 6). There is also a secondary north-northwest mode in the paleoflow data. Seven of the 13 results that form this mode were obtained from multiple sampling of the same 20 -cm-thick turbidite (see below). This is an unusually thick turbidite for the Site 944 levee, and it comes from the base of the levee succession. The levee at this site developed largely after avulsion from the older Brown Channel, the abandoned termination of which lies east of Site 944 (Fig. 1). The turbidity current that deposited this bed may have spilled from an upfan meander loop, or may have been an unusually large flow that perhaps used the then recently abandoned Brown Channel course. The northwest flow direction would be consistent with these scenarios. Alternatively, the northwest-oriented mode might record flow-normal magnetic alignments.

Site 946 is about $220 \mathrm{~km}$ downchannel from Site 944 . The levee of the Amazon Channel is composite at Site 946, being formed of an uppermost 18-m-thick recent levee wedge and an underlying approximately 25-m-thick levee unit that formed when the Amazon Channel was situated slightly farther west than at present (Flood, Piper, Klaus, et al., 1995, p. 635-636). The most recent channel is entrenched into sediments that predate both levee units, so that the relief between the levee crest and the channel talweg is $40 \mathrm{~m}$, similar to the full height of the composite levee unit. Before this latest incision of the channel, levee relief is believed to have been low, probably always $<25 \mathrm{~m}$. As a result, the levee contains more abundant silt and sand turbidites than levees higher on the fan (Fig. 2). AMS paleoflow is toward the east, orthogonal to the north-south orientation of the adjacent channel segment and directly down the backside of the youngest levee. Because the location of the bifurcation between the older and younger branches of the Amazon Channel is very close to this site, the deeper part of the levee probably had a crest orientation and backside slope direction similar to those of the most recent levee. Hence, the AMS paleoflow is consistent throughout the entire levee succession.

\section{Paleoflow Variations within Single Turbidites}

In 12 turbidites at Sites 934, 944, and 946, multiple samples were taken at different heights in each bed to examine the consistency of 

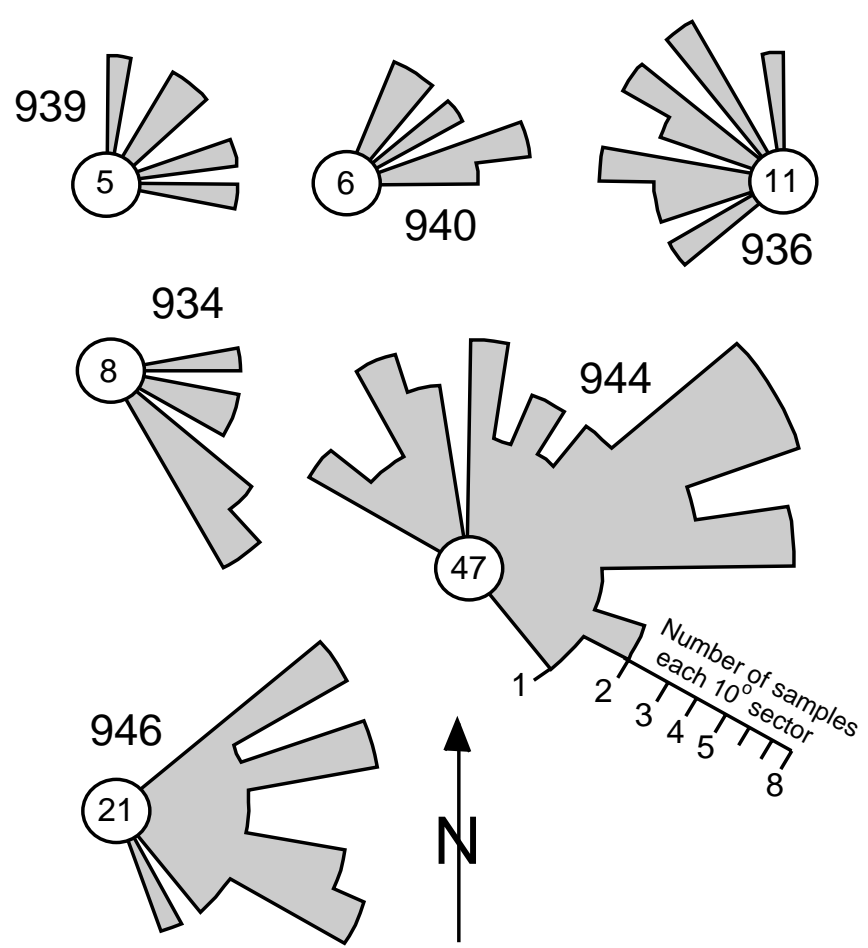

Figure 6. Equal-area rose diagrams of AMS paleoflow from sites on the levees of the Amazon Channel. On these plots, the radial scale varies as the square root of the number of samples (Nemec, 1988). The total number of samples is given at the center of each current rose.

paleoflow directions during deposition from a single turbidity current. The AMS paleoflow determinations indicate apparent deviations in flow direction with time (Fig. 8). Swings of this type have been described elsewhere by Parkash and Middleton (1970), Ledbetter and Ellwood (1980), and Hiscott and Middleton (1980). Because most of the swings are progressive rather than abrupt, we favor the interpretation of Parkash and Middleton (1970) that such unconfined turbidity currents are characterized by a shifting pattern of meandering streamlines in the flow as deposition proceeds. In several cases, there is a consistent swing in paleoflow during deposition, suggesting that some subtle topography on the levee might have forced the turbidity current to deviate progressively to one side of its initial path as it lost momentum. The modern SeaBeam bathymetry cannot be used to infer past details of levee shape, so it is not possible to discover the nature of this hypothetical topography.

\section{GRAIN-SIZE DATA}

Only highlights of turbidite grain size will be presented here. $\mathrm{Cu}-$ mulative data for all samples are available in Table 2 (also on CDROM, back pocket, this volume; for an explanation of this table, see Cramp et al., this volume). From the upper to the lower fan, the median sizes of the basal samples from turbidites increase, on average (Fig. 9), and levee heights decrease. Experience from both ODP and piston coring on the Amazon Fan indicates that the high levees are finer grained than the low levees, presumably because the more coarse-grained suspended load from the lower part of a turbidity current can only contribute to the overspill if the levee is low relative to total flow height. Recall that the turbidity currents transiting the channel, as they thicken because of water entrainment, are expected to lose some of their flow thickness because of overspill; this lost suspension is finer grained than the part of the flow that remains in the channel. Therefore, at outer fan localities like Site 946, the sediment

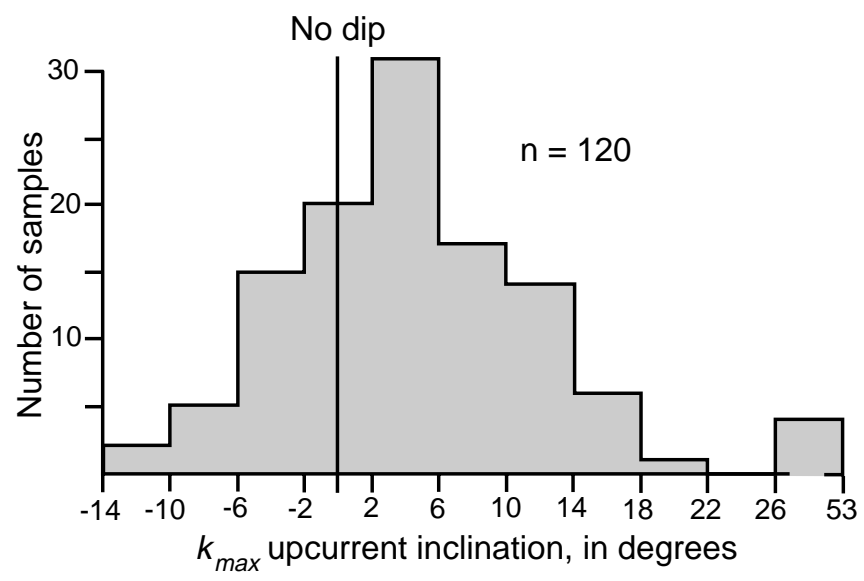

Figure 7. Upcurrent inclination of the major axis of the anisotropy ellipse $\left(k_{\max }\right)$, where the upcurrent direction was determined subjectively by examining the SeaBeam bathymetry around each site relative to potential sources of overbank spill. In cases of negative inclination, there is an apparent downcurrent imbrication of magnetic grains. These unexpected negative results are attributed to an inability to properly correct for all bedding dip induced by APC coring. Error limits on inclination determinations are probably about $\pm 5^{\circ}$ (compare Hiscott and Middleton, 1980).

available to generate spillover deposits will be coarser than on the upper and middle fan. Because the levees are also lower in this area (pre-incision levees may have only been about $25 \mathrm{~m}$ high), fluid turbulence is able to lift a significant amount of this coarser sediment load high enough in the flow for it to overtop the levees.

At the upper fan Site 939, with its high levees, even the coarsest examples of spillover turbidites are fine grained and poorly sorted (Fig. 10). Generally less than $1 \%$ (by weight) of sand is present in these turbidites. At typical middle fan Sites 940, 936, and 944, there is a common shape to the grain-size profiles (Fig. 11), with a wellsorted coarse-to-medium silt population separated from a more poorly sorted fine silt and clay population by a prominent change in slope when plotted on probability paper. The "kink" in the grain-size profiles occurs in the range 6-7 $\phi$ units.

Where two or more samples were taken from the same bed, the data indicate normal grading (Fig. 12A). However, grading is irregular in some beds (e.g., Fig. 12B), and other beds are essentially ungraded (e.g., Fig. 12C) except where they pass into mud at the bed top.

For beds with 1- to 2-mm interlaminated silt and mud at their tops (expanded $\mathrm{T}_{\mathrm{d}}$ divisions; see also Piper and Deptuck, this volume), both fine and coarse laminae have convex upward grain-size profiles with a "kink" in the range 6-7 $\phi$ units (Fig. 13). It had been anticipated, based on theory and examination of thin sections (Fig. 14), that the sorting that produced the laminae of the $T_{d}$ division might have efficiently separated the coarse-to-medium silt and fine silt to clay modes (Stow and Bowen, 1980; Hesse and Chough, 1980), but this proved not to be the case.

Site 934 is an unusual middle fan levee site because of its location in a hanging meander loop. Because the hanging valley taps overspill from a deeper level in Amazon Channel turbidity currents than other nearby levee saddle points, the turbidites at Site 934 are thicker and coarser grained than at Sites 940, 936, and 944 (Figs. 2, 9). Sand forms $20 \%$ of one sample (Fig. 15A). Sampled beds show irregular or normal grading (Fig. 15A, B).

At the lower fan Site 946, low levees are incapable of preventing the overspill of abundant sand, which was unable to escape the channel farther up the fan except in minor amounts. The overspill deposits that we sampled contain as much as $65 \%$ sand (Fig. 16). There is a "kink" in all grain-size profiles, at a somewhat coarser position than on the middle fan (about 5-6 $\phi$ units compared with 6-7 $\phi$ units on the middle fan). Some beds show normal grading (Fig. 17A), but in 

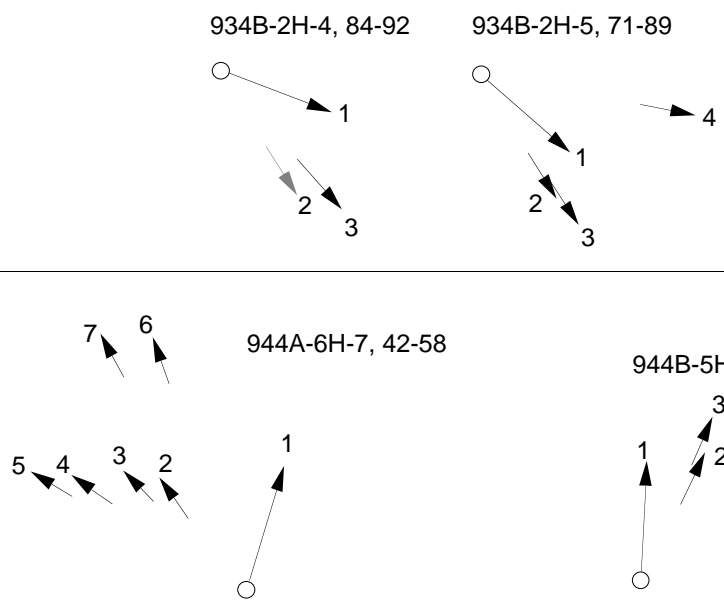

944D-4H-6, 37-41

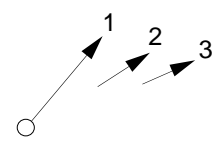

944D-5H-7, 57-86

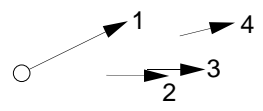

944B-5H-3, 50-55

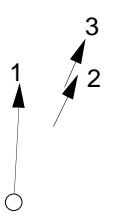

946A-1H-2, 79-89

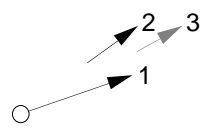

$946 \mathrm{~A}-1 \mathrm{H}-2,139$ to $-1 \mathrm{H}-3,2$

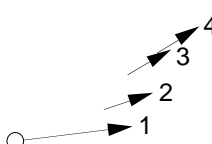

944D-3H-5, 64-71
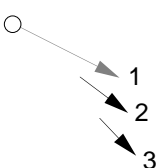

3

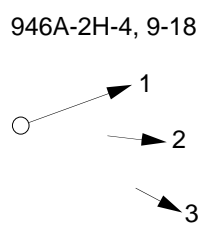

3
$946 \mathrm{~A}-5 \mathrm{H}-1,46-59$

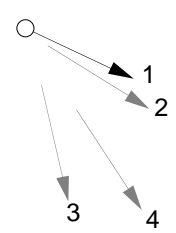

$946 \mathrm{~A}-2 \mathrm{H}-2,75-80$

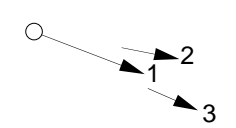

some cases this is restricted to the coarser part of the size distribution (Fig. 17B).

\section{Origin of the Kinks in Grain-Size Profiles}

Natural grain-size populations are generally considered to have frequency distributions that are either log-normal (Spencer, 1963; Folk, 1974) or log-hyperbolic (Bagnold and Barndorff-Nielsen, 1980; Christiansen et al., 1984). The Amazon Fan samples, with their prominent "kink" in the range of 5-7 $\phi$ units, fit neither of these distributions. Here, we will focus on the log-normal model. For sediment that has a log-normal distribution, a plot of cumulative data on probability paper yields a straight line (Folk, 1974). If two straight line segments are present, as is the case for our levee samples, a common interpretation is that each sample consists of a mixture of two populations, one of which is better sorted than the other (e.g., Visher,
1969; Middleton, 1976). An alternate interpretation, however, is that the segmented grain-size profiles are an artifact of sample dispersion in the laboratory. The "kinks" in the plots for the Amazon Fan samples occur at sizes for which electrostatic cohesive forces become important. For example, McCave (1981) showed that muds from North Sea coastal waters have a prominent mode in the interval 5-7 $\phi$ units that collapses after removal of organic matter; after treatment, the proportion of the sample in the range $8-9 \phi$ units increases dramatically, indicating that sample treatment caused the disaggregation of primary mud floccules.

AmasSeds Research Group (1990) and Kineke et al. (1991) report sediment concentrations of $10-100 \mathrm{~g} / \mathrm{L}(0.4 \%-4 \%)$ in shelf waters seaward of the mouth of the modern Amazon River. Gibbs and Konwar (1986) indicate strong flocculation on the shelf that increases effective particle size significantly. The rapid accumulation rates of Pleistocene Amazon Fan levees are consistent with periodic hyper- 
Table 2. Grain-size data for Amazon Channel levee turbidites.

\begin{tabular}{|c|c|c|c|c|c|c|c|c|c|c|c|c|c|c|c|c|c|c|c|}
\hline \multirow[b]{2}{*}{$\begin{array}{l}\text { Core, section, } \\
\text { interval }(\mathrm{cm})\end{array}$} & \multicolumn{19}{|c|}{ Cumulative percentages coarser than specified grain size ( $\mu \mathrm{m}$ and $\phi$ units) } \\
\hline & $\begin{array}{c}250 \mu \mathrm{m} \\
2 \phi\end{array}$ & $\begin{array}{c}177 \mu \mathrm{m} \\
2.5 \phi\end{array}$ & $\begin{array}{c}125 \mu \mathrm{m} \\
3 \phi\end{array}$ & $\begin{array}{c}88 \mu \mathrm{m} \\
3.5 \phi\end{array}$ & $\begin{array}{c}63 \mu \mathrm{m} \\
4 \phi\end{array}$ & $\begin{array}{c}44 \mu \mathrm{m} \\
4.5 \phi\end{array}$ & $\begin{array}{c}31 \mu \mathrm{m} \\
5 \phi\end{array}$ & $\begin{array}{c}22 \mu \mathrm{m} \\
5.5 \phi\end{array}$ & $\begin{array}{c}16 \mu \mathrm{m} \\
6 \phi\end{array}$ & $\begin{array}{c}11 \mu \mathrm{m} \\
6.5 \phi\end{array}$ & $\begin{array}{c}7.8 \mu \mathrm{m} \\
7 \phi\end{array}$ & $\begin{array}{c}5.5 \mu \mathrm{m} \\
7.5 \phi\end{array}$ & $\begin{array}{c}3.9 \mu \mathrm{m} \\
8 \phi\end{array}$ & $\begin{array}{c}2.8 \mu \mathrm{m} \\
8.5 \phi\end{array}$ & $\begin{array}{c}2.0 \mu \mathrm{m} \\
9 \phi\end{array}$ & $\begin{array}{c}1.4 \mu \mathrm{m} \\
9.5 \phi\end{array}$ & $\begin{array}{c}0.98 \mu \mathrm{m} \\
10 \phi\end{array}$ & $\begin{array}{c}0.69 \mu \mathrm{m} \\
10.5 \phi\end{array}$ & $\begin{array}{c}0.49 \mu \mathrm{m} \\
11 \phi\end{array}$ \\
\hline $\begin{array}{l}155-931 \mathrm{~A}- \\
4 \mathrm{H}-2,78-80[\mathrm{f}] \\
4 \mathrm{H}-2,78-80[\mathrm{c}] \\
4 \mathrm{H}-3,107-109[\mathrm{f}]\end{array}$ & $\bar{z}$ & $\bar{z}$ & $\bar{z}$ & $\bar{z}$ & $\begin{array}{l}0.19 \\
0.20 \\
0.20\end{array}$ & $\begin{array}{l}0.49 \\
0.20 \\
0.50\end{array}$ & $\begin{array}{l}3.48 \\
2.70 \\
1.20\end{array}$ & $\begin{array}{r}14.76 \\
13.60 \\
5.30\end{array}$ & $\begin{array}{l}32.73 \\
34.80 \\
15.60\end{array}$ & $\begin{array}{l}47.20 \\
54.00 \\
26.80\end{array}$ & $\begin{array}{l}55.68 \\
64.90 \\
37.10\end{array}$ & $\begin{array}{l}60.97 \\
70.00 \\
44.90\end{array}$ & $\begin{array}{l}64.67 \\
74.30 \\
51.30\end{array}$ & $\begin{array}{l}67.86 \\
77.90 \\
56.10\end{array}$ & $\begin{array}{l}71.06 \\
80.50 \\
60.90\end{array}$ & $\begin{array}{l}73.95 \\
82.90 \\
64.70\end{array}$ & $\begin{array}{l}76.64 \\
85.20 \\
68.50\end{array}$ & $\begin{array}{l}79.04 \\
86.70 \\
71.60\end{array}$ & $\begin{array}{l}81.24 \\
89.00 \\
75.30\end{array}$ \\
\hline $\begin{array}{l}155-934 \mathrm{~B}- \\
1 \mathrm{H}-5,0-2 \\
2 \mathrm{H}-4,83-85 \\
2 \mathrm{H}-4,89-91 \\
2 \mathrm{H}-4,91-93 \\
2 \mathrm{H}-5,49-51 \\
2 \mathrm{H}-5,70-72 \\
2 \mathrm{H}-5,77-79 \\
2 \mathrm{H}-5,83-85 \\
2 \mathrm{H}-5,88-90\end{array}$ & $\begin{array}{l}\bar{z} \\
\overline{\overline{1.20}} \\
\bar{z} \\
\bar{z} \\
\overline{-}\end{array}$ & $\begin{array}{l}\bar{z} \\
\bar{z} \\
\bar{z} 0 \\
\bar{z} \\
\bar{z}\end{array}$ & $\begin{array}{l}\bar{z} \\
\overline{\overline{1.50}} \\
\bar{z} \\
= \\
=\end{array}$ & $\begin{array}{l}\bar{z} \\
\overline{7.80} \\
\bar{z} \\
\bar{z} \\
\overline{-}\end{array}$ & $\begin{array}{r}1.10 \\
0.54 \\
8.61 \\
2.90 \\
4.83 \\
1.05 \\
3.66 \\
5.99 \\
2.02\end{array}$ & $\begin{array}{r}4.80 \\
8.30 \\
27.53 \\
50.30 \\
20.25 \\
9.16 \\
17.92 \\
18.74 \\
11.62\end{array}$ & $\begin{array}{l}22.67 \\
29.18 \\
52.11 \\
72.10 \\
50.61 \\
28.56 \\
44.22 \\
43.84 \\
30.24\end{array}$ & $\begin{array}{l}46.99 \\
52.76 \\
69.02 \\
83.40 \\
72.69 \\
47.46 \\
62.52 \\
65.88 \\
51.60\end{array}$ & $\begin{array}{l}62.22 \\
66.88 \\
76.33 \\
87.86 \\
81.16 \\
59.23 \\
70.23 \\
77.38 \\
65.51\end{array}$ & $\begin{array}{l}69.05 \\
74.24 \\
79.80 \\
90.31 \\
84.87 \\
65.66 \\
75.24 \\
82.94 \\
72.66\end{array}$ & $\begin{array}{l}73.00 \\
78.22 \\
81.72 \\
91.67 \\
87.15 \\
68.83 \\
78.03 \\
86.68 \\
77.66\end{array}$ & $\begin{array}{l}76.56 \\
81.10 \\
83.09 \\
93.09 \\
89.15 \\
72.49 \\
80.54 \\
88.88 \\
80.89\end{array}$ & $\begin{array}{l}79.63 \\
83.29 \\
85.19 \\
94.19 \\
90.58 \\
75.76 \\
82.66 \\
90.42 \\
83.34\end{array}$ & $\begin{array}{l}82.00 \\
84.98 \\
87.02 \\
94.96 \\
91.72 \\
78.03 \\
84.01 \\
92.24 \\
85.40\end{array}$ & $\begin{array}{l}83.88 \\
87.27 \\
88.76 \\
95.67 \\
93.15 \\
81.00 \\
85.74 \\
94.63 \\
87.16\end{array}$ & $\begin{array}{l}85.86 \\
89.16 \\
90.77 \\
96.25 \\
94.19 \\
82.68 \\
87.86 \\
96.07 \\
88.83\end{array}$ & $\begin{array}{l}87.44 \\
90.65 \\
90.68 \\
96.71 \\
95.15 \\
83.57 \\
88.82 \\
97.70 \\
90.89\end{array}$ & $\begin{array}{l}89.81 \\
92.74 \\
91.96 \\
97.48 \\
96.10 \\
86.74 \\
89.98 \\
99.04 \\
93.73\end{array}$ & $\begin{array}{r}91.69 \\
93.83 \\
93.60 \\
97.87 \\
96.38 \\
89.71 \\
90.37 \\
100.19 \\
95.30\end{array}$ \\
\hline $\begin{array}{l}\text { 155-936A- } \\
\text { 2H-6, 14-16 } \\
2 \mathrm{H}-6,19-21 \\
2 \mathrm{H}-6,37-39 \\
2 \mathrm{H}-6,72-74 \\
2 \mathrm{H}-6,81-83 \\
3 \mathrm{H}-1,43-45 \\
3 \mathrm{H}-5,74-76 \\
4 \mathrm{H}-2,21-23 \\
4 \mathrm{H}-4,73-75 \\
4 \mathrm{H}-4,75-77 \\
4 \mathrm{H}-6,44-46 \\
5 \mathrm{H}-7,71-73 \\
5 \mathrm{H}-7,82-84\end{array}$ & $\begin{array}{l}= \\
= \\
= \\
= \\
= \\
= \\
= \\
= \\
=\end{array}$ & $\begin{array}{l}= \\
= \\
= \\
= \\
= \\
= \\
= \\
= \\
=\end{array}$ & $\begin{array}{l}= \\
= \\
= \\
= \\
= \\
= \\
= \\
= \\
=\end{array}$ & $\begin{array}{l}= \\
= \\
= \\
= \\
= \\
= \\
= \\
=\end{array}$ & $\begin{array}{l}3.04 \\
3.44 \\
0.38 \\
0.10 \\
1.39 \\
0.49 \\
1.00 \\
1.35 \\
2.81 \\
0.58 \\
2.35 \\
1.79 \\
0.78\end{array}$ & $\begin{array}{r}15.16 \\
11.16 \\
0.18 \\
0.50 \\
7.21 \\
2.58 \\
4.37 \\
4.01 \\
9.03 \\
16.06 \\
8.50 \\
8.47 \\
7.03\end{array}$ & $\begin{array}{r}43.08 \\
33.28 \\
4.56 \\
2.90 \\
28.70 \\
10.74 \\
20.11 \\
19.01 \\
27.40 \\
45.47 \\
25.10 \\
28.21 \\
28.34\end{array}$ & $\begin{array}{l}69.17 \\
60.02 \\
20.01 \\
11.10 \\
58.39 \\
27.76 \\
40.40 \\
41.30 \\
51.21 \\
71.95 \\
44.44 \\
54.14 \\
57.68\end{array}$ & $\begin{array}{l}81.97 \\
77.12 \\
44.21 \\
23.70 \\
76.73 \\
44.77 \\
54.96 \\
58.57 \\
68.61 \\
84.13 \\
57.72 \\
72.70 \\
75.91\end{array}$ & $\begin{array}{l}87.30 \\
84.36 \\
62.64 \\
34.90 \\
84.12 \\
55.72 \\
63.47 \\
67.45 \\
77.06 \\
88.41 \\
65.43 \\
81.54 \\
83.65\end{array}$ & $\begin{array}{l}90.11 \\
87.54 \\
73.00 \\
42.80 \\
87.58 \\
62.39 \\
68.52 \\
72.87 \\
81.63 \\
90.36 \\
70.31 \\
85.86 \\
86.82\end{array}$ & $\begin{array}{l}91.47 \\
89.09 \\
78.78 \\
49.20 \\
89.55 \\
67.26 \\
72.48 \\
76.82 \\
84.74 \\
91.72 \\
74.61 \\
88.61 \\
88.90\end{array}$ & $\begin{array}{l}93.02 \\
90.73 \\
82.57 \\
54.20 \\
91.42 \\
70.84 \\
75.35 \\
79.88 \\
87.07 \\
92.50 \\
77.74 \\
90.47 \\
90.68\end{array}$ & $\begin{array}{l}93.70 \\
91.70 \\
85.26 \\
58.60 \\
92.70 \\
74.03 \\
77.92 \\
81.85 \\
88.43 \\
93.57 \\
80.47 \\
93.52 \\
91.77\end{array}$ & $\begin{array}{l}94.67 \\
92.95 \\
87.55 \\
62.80 \\
94.28 \\
77.61 \\
80.50 \\
83.82 \\
89.99 \\
94.64 \\
83.11 \\
94.79 \\
92.76\end{array}$ & $\begin{array}{l}95.44 \\
93.72 \\
89.54 \\
66.90 \\
95.27 \\
80.10 \\
82.68 \\
85.99 \\
91.64 \\
96.01 \\
85.55 \\
95.29 \\
93.95\end{array}$ & $\begin{array}{l}95.83 \\
94.88 \\
91.13 \\
70.00 \\
95.96 \\
82.69 \\
84.16 \\
87.57 \\
93.59 \\
96.49 \\
87.11 \\
97.74 \\
94.85\end{array}$ & $\begin{array}{l}96.61 \\
95.65 \\
92.83 \\
73.20 \\
97.34 \\
85.67 \\
86.44 \\
89.25 \\
95.33 \\
97.47 \\
89.84 \\
98.63 \\
95.94\end{array}$ & $\begin{array}{l}97.38 \\
96.14 \\
94.72 \\
75.40 \\
99.01 \\
88.16 \\
88.52 \\
91.22 \\
96.50 \\
97.66 \\
92.19 \\
99.00 \\
97.32\end{array}$ \\
\hline $\begin{array}{l}\text { 155-939B- } \\
4 \mathrm{H}-2,70-72 \\
4 \mathrm{H}-6,4-6 \\
5 \mathrm{H}-6,77-79 \\
5 \mathrm{H}-\mathrm{CC}, 30-32 \\
6 \mathrm{H}-3,52-54\end{array}$ & $\begin{array}{l}= \\
\bar{z} \\
=\end{array}$ & $\begin{array}{l}= \\
= \\
=\end{array}$ & $\begin{array}{l}= \\
= \\
=\end{array}$ & $\begin{array}{l}= \\
= \\
=\end{array}$ & $\begin{array}{l}2.70 \\
0.53 \\
0.41 \\
0.21 \\
0.19\end{array}$ & $\begin{array}{l}4.16 \\
4.51 \\
0.91 \\
2.60 \\
2.69\end{array}$ & $\begin{array}{r}4.65 \\
12.96 \\
2.70 \\
3.30 \\
8.37\end{array}$ & $\begin{array}{r}6.20 \\
26.69 \\
8.58 \\
6.40 \\
15.66\end{array}$ & $\begin{array}{r}8.34 \\
39.02 \\
18.04 \\
11.99 \\
22.15\end{array}$ & $\begin{array}{l}12.33 \\
47.08 \\
27.80 \\
18.37 \\
28.74\end{array}$ & $\begin{array}{l}18.95 \\
52.35 \\
35.96 \\
24.36 \\
35.22\end{array}$ & $\begin{array}{l}25.66 \\
57.33 \\
43.93 \\
30.85 \\
41.71\end{array}$ & $\begin{array}{l}31.99 \\
61.80 \\
50.80 \\
37.03 \\
48.10\end{array}$ & $\begin{array}{l}39.58 \\
65.98 \\
56.68 \\
42.82 \\
53.39\end{array}$ & $\begin{array}{l}46.49 \\
70.16 \\
62.16 \\
48.81 \\
58.78\end{array}$ & $\begin{array}{l}53.69 \\
74.34 \\
67.43 \\
54.89 \\
63.07\end{array}$ & $\begin{array}{l}59.33 \\
78.12 \\
72.02 \\
61.08 \\
67.36\end{array}$ & $\begin{array}{l}65.56 \\
81.80 \\
76.50 \\
66.87 \\
71.95\end{array}$ & $\begin{array}{l}71.88 \\
84.98 \\
80.78 \\
72.16 \\
76.15\end{array}$ \\
\hline $\begin{array}{l}155-939 \mathrm{C}- \\
4 \mathrm{H}-3,128-130\end{array}$ & - & - & - & - & 0.53 & 4.41 & 21.02 & 43.80 & 59.91 & 68.27 & 72.84 & 75.83 & 78.22 & 80.01 & 82.39 & 84.48 & 86.07 & 87.67 & 89.85 \\
\hline $\begin{array}{c}155-940 \mathrm{~A}- \\
2 \mathrm{H}-6,98-100 \\
2 \mathrm{H}-7,25-27 \\
3 \mathrm{H}-6,11-13 \\
3 \mathrm{H}-6,13-15 \\
3 \mathrm{H}-6,112-144 \\
4 \mathrm{H}-2,38-41 \\
4 \mathrm{H}-5,35-38 \\
4 \mathrm{H}-5,127-130\end{array}$ & $\begin{array}{l}= \\
= \\
= \\
= \\
=\end{array}$ & $\begin{array}{l}= \\
= \\
= \\
= \\
=\end{array}$ & $\begin{array}{l}= \\
= \\
= \\
= \\
=\end{array}$ & $\begin{array}{l}= \\
= \\
= \\
= \\
=\end{array}$ & $\begin{array}{l}0.35 \\
0.18 \\
0.16 \\
0.00 \\
0.00 \\
0.53 \\
0.16 \\
0.14\end{array}$ & $\begin{array}{l}2.64 \\
0.08 \\
0.96 \\
1.90 \\
1.00 \\
2.02 \\
2.86 \\
1.24\end{array}$ & $\begin{array}{r}11.41 \\
3.47 \\
6.65 \\
12.60 \\
5.40 \\
5.11 \\
14.44 \\
1.94\end{array}$ & $\begin{array}{r}27.75 \\
15.05 \\
24.12 \\
40.40 \\
18.30 \\
13.26 \\
36.90 \\
6.13\end{array}$ & $\begin{array}{l}43.30 \\
34.72 \\
46.29 \\
67.30 \\
35.10 \\
23.51 \\
57.47 \\
15.22\end{array}$ & $\begin{array}{l}52.57 \\
50.49 \\
60.56 \\
78.80 \\
47.00 \\
32.76 \\
67.45 \\
25.20\end{array}$ & $\begin{array}{l}58.55 \\
60.47 \\
68.35 \\
82.70 \\
55.20 \\
40.02 \\
72.14 \\
34.09\end{array}$ & $\begin{array}{l}63.33 \\
66.36 \\
72.94 \\
85.00 \\
61.10 \\
46.19 \\
75.54 \\
41.98\end{array}$ & $\begin{array}{l}67.22 \\
70.65 \\
76.34 \\
86.50 \\
65.60 \\
52.06 \\
77.84 \\
48.67\end{array}$ & $\begin{array}{l}70.20 \\
73.85 \\
78.83 \\
87.80 \\
69.30 \\
56.73 \\
79.63 \\
53.86\end{array}$ & $\begin{array}{l}73.89 \\
76.24 \\
81.23 \\
89.10 \\
72.90 \\
61.31 \\
81.73 \\
58.96\end{array}$ & $\begin{array}{l}76.48 \\
78.74 \\
83.43 \\
90.20 \\
76.40 \\
65.68 \\
83.63 \\
63.05\end{array}$ & $\begin{array}{l}78.87 \\
81.53 \\
85.42 \\
91.10 \\
78.60 \\
69.66 \\
85.22 \\
66.55\end{array}$ & $\begin{array}{l}81.96 \\
84.33 \\
87.12 \\
92.50 \\
82.00 \\
73.44 \\
87.12 \\
70.14\end{array}$ & $\begin{array}{l}84.95 \\
86.42 \\
88.62 \\
93.90 \\
84.70 \\
76.82 \\
88.92 \\
73.14\end{array}$ \\
\hline $\begin{array}{l}155-944 \mathrm{~A}- \\
6 \mathrm{H}-4,23-25\end{array}$ & - & - & - & - & 0.18 & 2.08 & 8.07 & 28.63 & 52.69 & 66.16 & 72.65 & 76.74 & 79.44 & 81.23 & 83.33 & 85.13 & 86.62 & 88.82 & 90.92 \\
\hline
\end{tabular}


Table 2 (continued).

\begin{tabular}{|c|c|c|c|c|c|c|c|c|c|c|c|c|c|c|c|c|c|c|c|}
\hline \multirow{3}{*}{$\begin{array}{l}\text { Core, section, } \\
\text { interval }(\mathrm{cm})\end{array}$} & \multicolumn{19}{|c|}{ Cumulative percentages coarser than specified grain size ( $\mu \mathrm{m}$ and $\phi$ units) } \\
\hline & $250 \mu \mathrm{m}$ & $177 \mu \mathrm{m}$ & $125 \mu \mathrm{m}$ & $88 \mu \mathrm{m}$ & $63 \mu \mathrm{m}$ & $44 \mu \mathrm{m}$ & $31 \mu \mathrm{m}$ & $22 \mu \mathrm{m}$ & $16 \mu \mathrm{m}$ & $11 \mu \mathrm{m}$ & $7.8 \mu \mathrm{m}$ & $5.5 \mu \mathrm{m}$ & $3.9 \mu \mathrm{m}$ & $2.8 \mu \mathrm{m}$ & $2.0 \mu \mathrm{m}$ & $1.4 \mu \mathrm{m}$ & $0.98 \mu \mathrm{m}$ & $0.69 \mu \mathrm{m}$ & $0.49 \mu \mathrm{m}$ \\
\hline & $2 \phi$ & $2.5 \phi$ & $3 \phi$ & $3.5 \phi$ & $4 \phi$ & $4.5 \phi$ & $5 \phi$ & $5.5 \phi$ & $6 \phi$ & $6.5 \phi$ & $7 \phi$ & $7.5 \phi$ & $8 \phi$ & $8.5 \phi$ & $9 \phi$ & $9.5 \phi$ & $10 \phi$ & $10.5 \phi$ & $11 \phi$ \\
\hline $6 \mathrm{H}-4,50-52$ & - & - & - & - & 0.00 & 1.50 & 12.30 & 38.80 & 63.70 & 74.80 & 80.10 & 83.00 & 84.80 & 86.40 & 88.10 & 89.40 & 91.30 & 93.90 & 96.30 \\
\hline $6 \mathrm{H} 632$ & 列 & 列 & 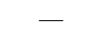 & 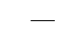 & 0.53 & 0.43 & 3.32 & 16.09 & 37.84 & 54.41 & 64.08 & 69.47 & 73.36 & & 78.95 & 81.24 & & 85.03 & \\
\hline $6 \mathrm{H}-$ & - & - & - & - & 0.46 & 3.45 & 18.78 & 47.14 & 70.34 & 80.59 & 84.67 & 86.66 & 88.65 & & 91.24 & 92 & & 23 & 02 \\
\hline $6 \mathrm{H}$ & - & - & - & - & 0.17 & 5.76 & 22.43 & 49.49 & 69.65 & 78.84 & 82.93 & 8. & 87 & 88 & 89 & 91 & 91 & 01 & 81 \\
\hline $6 \mathrm{H}-7$ & - & - & - & - & 0.34 & 4.13 & 23.36 & 54.26 & 74.99 & 82.86 & 86.05 & 87.94 & 89.54 & 90.53 & 91.73 & 92.63 & 2 & 2 & 94.92 \\
\hline $6 \mathrm{H}-7,49-51$ & - & - & - & - & 0.17 & 4.46 & 21.43 & 50.09 & 71.05 & 80.33 & 84.33 & 86.72 & 88.72 & 89.52 & 90.82 & 91.71 & 92.31 & 93.81 & 95.71 \\
\hline $6 \mathrm{H}-7,52-54$ & - & - & - & - & 0.69 & 7.74 & 28.79 & 56.60 & 73.68 & 80.54 & 83.51 & 85.80 & 87.49 & 88.38 & 90.27 & 90.96 & 91.36 & 92.65 & 93.25 \\
\hline $6 \mathrm{H}-7,54-56$ & - & - & - & - & 1.79 & 10.24 & 29.29 & 51.48 & 65.63 & 72.60 & 76.43 & 79.18 & 81.63 & 83.30 & 85.07 & 86.55 & 88.02 & 89.39 & 90.67 \\
\hline $6 \mathrm{H}-7,57-59$ & - & - & - & - & 2.77 & 15.99 & 47.50 & 74.33 & 84.93 & 88.53 & 90.08 & 91.44 & 92.32 & 93.19 & 94.07 & 94.56 & 94.75 & 95.82 & 95.92 \\
\hline $6 \mathrm{H}-\mathrm{CC}, 13-15$ & - & - & - & - & 0.16 & 2.36 & 13.24 & 39.40 & 64.26 & 76.34 & 81.93 & 84.82 & 86.72 & 88.42 & 89.72 & 90.52 & 91.61 & 92.81 & 94.01 \\
\hline 155-944B- & & & & & & & & & & & & & & & & & & & \\
\hline $1-92[\mathrm{f}]$ & - & - & - & - & 0.00 & 0.00 & 0.90 & 5.10 & 14.80 & 27.40 & 37.60 & 45.30 & 51.30 & 56.30 & 60.80 & 64.60 & 68.20 & 71.40 & 74.40 \\
\hline$-92[\mathrm{c}]$ & - & - & - & - & 0.00 & 0.00 & 0.00 & 16.50 & 38 & 52 & 58 & 64 & 67.82 & 69 & 3 & 0 & & & \\
\hline $4 \mathrm{H}-7$ & - & - & - & - & 020 & 020 & 1.90 & 6.79 & 16.07 & 26.75 & 35.93 & 43.11 & 49.30 & 54.39 & 59.18 & 63.17 & 66.87 & 70.66 & 74.05 \\
\hline $5 \mathrm{H}-3$ & - & - & - & - & 0 & 120 & 1.90 & 7.59 & 19.38 & 31.07 & 40 & 47.05 & 5 & 94 & 61.54 & 13 & 83 & 23 & 75.32 \\
\hline $5 \mathrm{H}-3$ & - & - & - & - & 0 & 3.56 & 12.31 & 30.73 & 48.44 & 58 & 64.17 & 5 & 71.34 & 22 & 1 & 30 & 89 & 07 & 87.56 \\
\hline $5 \mathrm{H}-3,54-56$ & - & - & - & - & 0.54 & 3.62 & 16.06 & 37.84 & 55.74 & 64.79 & 69.76 & 73.15 & 76.03 & 78.32 & 80.80 & 83.09 & 84.78 & 86.97 & 88.56 \\
\hline $155-9$ & & & & & & & & & & & & & & & & & & & \\
\hline-20 & - & - & - & - & 0.18 & 7.27 & 28.43 & 56.38 & 73.55 & 80.44 & 83.43 & 85.73 & 87.42 & 88.32 & 90.22 & 90.92 & 91.32 & 92.61 & 93.21 \\
\hline $3 \mathrm{H}-2,58-60$ & - & 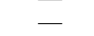 & - & - & 0.00 & 1.60 & 3.70 & 17.10 & 39.90 & 57.10 & 66.30 & 71.40 & & 77.60 & 80.00 & & & & 88.90 \\
\hline & - & - & - & - & & 0. & 8. & 29 & 54.98 & & 74 & & & & & & & & 90.32 \\
\hline & $ב$ & ב & 二 & 二 & & 1. & 4. & 14 & 32.22 & $\begin{array}{l}08 \\
47\end{array}$ & $\begin{array}{l}14 \\
56\end{array}$ & & & & & & $\begin{array}{l}79.82 \\
79.44\end{array}$ & $\begin{array}{l}8.52 \\
81.73\end{array}$ & 83.63 \\
\hline $3 \mathrm{H}$ & - & - & - & - & 0 & 3.84 & 14.73 & 42 & 70 & 82 & 87 & 88 & & 91 & 92 & 1 & 94.61 & 95.21 & 96.11 \\
\hline & - & - & - & - & & & 5.47 & 19 & 43 & 59 & & & & & & & 8754 & 89.53 & 91.62 \\
\hline & - & 二 & 二 & 二 & & & & & & & & 65 & 69. & & & & & & \\
\hline $121-123$ & - & - & - & - & 0.1 & 1.37 & 6.26 & 22.93 & 48.09 & 65.56 & 73.94 & 78. & 81 & 83.73 & 85.52 & 87 & 89 & 90.32 & 91.51 \\
\hline $3 \mathrm{H}-3,124-126$ & - & - & - & - & 0 . & 1.10 & 3.10 & 9.40 & 21.90 & 34.30 & 43. & 50. & 56.00 & 60.80 & 65.10 & 69.10 & 72.90 & 76.40 & 80.20 \\
\hline & - & - & - & - & & & 12.25 & 34 & & & & & 82 & 84 & & 87.82 & 89.52 & 91.31 & 92.31 \\
\hline & - & - & - & - & 0 & 1. & 5.8 & 19 & 40 & 54 & 61 & 66 & 69 & 73 & 75.54 & 78.14 & 80.73 & 83.13 & 85.42 \\
\hline & - & - & - & - & & 2. & 7. & 24 & & 66 & & 77 & & & 84 & & 88.52 & & 91.61 \\
\hline & 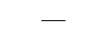 & - & - & - & & 2 & 4 & & & & & & & & & & & & 88.72 \\
\hline & - & - & - & - & 0 & 0. & 8 & & & & & & & 90 & 91 & & & & 95.31 \\
\hline $3 \mathrm{H}$ & - & 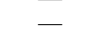 & - & 二 & 0. & 1. & $\begin{array}{r}0 \\
10\end{array}$ & 35 & 63 & & 86. & 89 & $\begin{array}{l}00 \\
90\end{array}$ & 91. & 92.40 & 93.40 & 94.60 & 95.60 & 95.60 \\
\hline $3 \mathrm{H}$ & 二 & 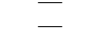 & 二 & 二 & 0 & 1. & 8. & 27 & 51. & 66 & $\begin{array}{l}\text { o0. } \\
72 .\end{array}$ & $\begin{array}{l}79 \\
77\end{array}$ & 79 & $\begin{array}{l}91 \\
82\end{array}$ & 83.90 & 86 & 0 & 89.90 & 91.50 \\
\hline & 二 & 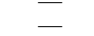 & $z$ & 二 & & 5. & 20. & 47 & $\begin{array}{l}51 \\
70\end{array}$ & $\begin{array}{l}00 \\
80\end{array}$ & 84 & 87 & & 90 & $\begin{array}{l}83 \\
91\end{array}$ & $\begin{array}{l}80 \\
93\end{array}$ & 2 & $\begin{array}{l}95.00 \\
95.00\end{array}$ & $\begin{array}{l}11.000 \\
96.31\end{array}$ \\
\hline & - & - & - & - & 0 & 0.47 & 3. & 13 & 28 & 40. & 50 & 56. & 61 & & 70 & 74.14 & 76.84 & 80.13 & 82.83 \\
\hline & - & - & - & - & & & 14 & & & & & & & & & & & & 94.31 \\
\hline & - & - & - & - & & & & & & & & & & & & & & & \\
\hline & - & - & - & - & & & & & & & & & & & & & & & \\
\hline & 二 & 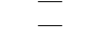 & - & 二 & & & 18 & & & & & & & & & & & & $\begin{array}{l}95.02 \\
95.12\end{array}$ \\
\hline & - & 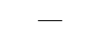 & - & - & & & & & & & & & & & & & & & 89.12 \\
\hline & & 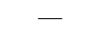 & 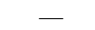 & 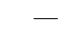 & & & & & & & & & & & & & & 88.32 & 89.62 \\
\hline & 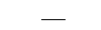 & 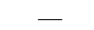 & - & - & 0. & 4. & 22.5 & 52 & 74 & 83 & 87 & 89.42 & 91. & 92.11 & 93.01 & 93.61 & 94.21 & 95.41 & 95.71 \\
\hline & - & - & - & - & 0.00 & 1.9 & 5.80 & 20.00 & 41.9 & 57.60 & 66. & 71.50 & 75.20 & 78.00 & 80.30 & 82.50 & 84.80 & 87.30 & 89.30 \\
\hline $4 \mathrm{H}-5,52-54[\mathrm{f}]$ & 二 & 二 & 二 & 二 & 0.00 & 0.00 & 1.00 & 7.70 & 23.00 & 38.70 & 48.80 & 55.90 & 60.70 & 64.90 & 68.50 & 71.70 & 74.30 & $\begin{array}{l}0.00 \\
77.00\end{array}$ & 79.50 \\
\hline $4 \mathrm{H}-5,52-54[\mathrm{c}]$ & 二 & 二 & 二 & 二 & 0.00 & 0.00 & 4.88 & 33.44 & 60.71 & 71.51 & $\begin{array}{l}40.00 \\
77.17\end{array}$ & 80.00 & & & & & & & \\
\hline $4 \mathrm{H}-6,36-38$ & 二 & 二 & 二 & 二 & 0.00 & 0.00 & $\begin{array}{l}4.00 \\
0.70\end{array}$ & 2.30 & 7.60 & 15.20 & 23.20 & 31.40 & 38.8 & 45 . & 51. & $5 \overline{6.80}$ & $6 \overline{1.70}$ & $6 \overline{6.30}$ & $7 \overline{1.60}$ \\
\hline & - & - & - & - & & & 7. & $26-2+2$ & 40 & 10 & & & & & & & & & \\
\hline & - & - & - & - & 1.90 & 3.79 & 16.65 & 45.46 & 72 & 84 & 89 & 91 & 93.52 & 95. & 96. & 97.51 & 99.10 & 99.90 & 40 \\
\hline
\end{tabular}


Table 2 (continued)

\begin{tabular}{|c|c|c|c|c|c|c|c|c|c|c|c|c|c|c|c|c|c|c|c|}
\hline \multirow{3}{*}{$\begin{array}{l}\text { Core, section, } \\
\text { interval }(\mathrm{cm})\end{array}$} & \multicolumn{19}{|c|}{ Cumulative percentages coarser than specified grain size ( $\mu \mathrm{m}$ and $\phi$ units) } \\
\hline & $250 \mu \mathrm{m}$ & $177 \mu \mathrm{m}$ & $125 \mu \mathrm{m}$ & $88 \mu \mathrm{m}$ & $63 \mu \mathrm{m}$ & $44 \mu \mathrm{m}$ & $31 \mu \mathrm{m}$ & $22 \mu \mathrm{m}$ & $16 \mu \mathrm{m}$ & $11 \mu \mathrm{m}$ & $7.8 \mu \mathrm{m}$ & $5.5 \mu \mathrm{m}$ & $3.9 \mu \mathrm{m}$ & $2.8 \mu \mathrm{m}$ & $2.0 \mu \mathrm{m}$ & $1.4 \mu \mathrm{m}$ & $0.98 \mu \mathrm{m}$ & $0.69 \mu \mathrm{m}$ & $0.49 \mu \mathrm{m}$ \\
\hline & $2 \phi$ & $2.5 \phi$ & $3 \phi$ & $3.5 \phi$ & $4 \phi$ & $4.5 \phi$ & $5 \phi$ & $5.5 \phi$ & $6 \phi$ & $6.5 \phi$ & $7 \phi$ & $7.5 \phi$ & $8 \phi$ & $8.5 \phi$ & $9 \phi$ & $9.5 \phi$ & $10 \phi$ & $10.5 \phi$ & $11 \phi$ \\
\hline $5 \mathrm{H}-7,56-58[\mathrm{c}]$ & - & - & - & - & 0.00 & 0.00 & 3.57 & 27.17 & 46.94 & 57.37 & 62.59 & 65.88 & 70.00 & 6 & 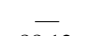 & 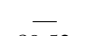 & 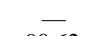 & & \\
\hline $5 \mathrm{H}-7,60-62$ & - & - & - & - & 0.16 & 2.56 & 14.94 & 40.79 & 64.06 & 75.64 & 80.53 & 83.13 & 85.32 & 86.82 & 88.12 & 89.52 & 90.62 & 92.31 & 93.21 \\
\hline $5 \mathrm{H}-7,79-81$ & - & - & - & - & 1.23 & $\begin{array}{r}4.69 \\
1302\end{array}$ & $\begin{array}{l}20.10 \\
3855\end{array}$ & 43.70 & 61.78 & 71.46 & $\begin{array}{l}76.00 \\
8150\end{array}$ & 78.96 & $\begin{array}{l}81.43 \\
8793\end{array}$ & $\begin{array}{l}83.41 \\
8871\end{array}$ & 85.38 & 87.26 & 88.94 & 90.72 & 92.30 \\
\hline $5 \mathrm{H}-7,85-87$ & - & - & - & - & 1.83 & 13.02 & 38.55 & 63.38 & 76.73 & 82.03 & 84.59 & 86.45 & 87.83 & 88.71 & 90.18 & 92.05 & 92.93 & 93.82 & 94.40 \\
\hline $155-946 \mathrm{~A}-$ & & & & & & & & & & & & & & & & & & & \\
\hline $1 \mathrm{H}-2,23-25$ & - & - & - & - & 0.57 & 3.25 & 11.51 & 29.70 & 50.68 & 63.71 & 70.17 & 74.25 & 76.83 & 79.12 & 81.31 & 83.40 & 85.48 & 86.97 & 89.06 \\
\hline $1 \mathrm{H}-2,29-31$ & 0.60 & 0.70 & 1.10 & 2.50 & 6.20 & 25.10 & 52.79 & 72.86 & 81.79 & 85.41 & 87.45 & 88.68 & 89.66 & 90.81 & 91.34 & 92.31 & 93.10 & 93.99 & 95.14 \\
\hline $1 \mathrm{H}-2,35-37$ & 0.00 & 0.90 & 3.20 & 11.50 & 29.40 & 53.10 & 69.81 & 78.50 & 82.79 & 84.97 & 86.49 & 87.84 & 89.02 & 90.37 & 91.19 & 92.31 & 93.42 & 94.36 & 95.42 \\
\hline $1 \mathrm{H}-2,78-80$ & 0.00 & 0.90 & 5.20 & 11.00 & $\begin{array}{r}2.40 \\
1.25\end{array}$ & 4.90 & $\begin{array}{l}0.01 \\
17.94\end{array}$ & 40.95 & 61.19 & $\begin{array}{l}7.9 .25 \\
72.25\end{array}$ & $\begin{array}{l}00.49 \\
77.29\end{array}$ & $\begin{array}{l}0.04 \\
80.45\end{array}$ & 82.52 & 84.40 & 86.27 & 87.76 & $\begin{array}{l}89.14 \\
89.14\end{array}$ & $\begin{array}{l}94.000 \\
90.62\end{array}$ & 92.30 \\
\hline $1 \mathrm{H}-2,83-85$ & 0.40 & 1.00 & 1.80 & 3.90 & 10.90 & 35.18 & 60.05 & 75.46 & 82.26 & 85.58 & 87.07 & 88.23 & 89.39 & 90.47 & 91.13 & 92.37 & 93.29 & 94.03 & 94.86 \\
\hline $1 \mathrm{H}-2,88-91$ & 0.40 & 1.20 & 2.40 & 6.90 & 16.20 & 41.76 & 64.7 & 79.5 & 85.5 & 87.99 & 89.49 & 90.69 & 91.44 & 92.42 & 93.10 & 94.07 & 94.82 & 95.72 & 96.25 \\
\hline $1 \mathrm{H}-2,1$ & - & - & - & - & 2.00 & 8.76 & 32.77 & 61.49 & 77.56 & 83.63 & 86.2 & 88.14 & 89.42 & 90.98 & 92.16 & 93.04 & 94.41 & 95.20 & 95.79 \\
\hline $1 \mathrm{H}-2,141-143$ & - & - & - & - & 6.64 & 19.06 & 45.94 & 67.70 & 78.06 & 82.54 & 84.78 & 86.46 & 7.77 & 89.08 & 90.10 & 91.22 & 92.90 & 94.02 & 95.15 \\
\hline $1 \mathrm{H}-2,145-148$ & - & - & - & - & 24.63 & 38.27 & 58.62 & 71.81 & 78.14 & 81.16 & 83.19 & 84.47 & 85.60 & 87.04 & 88.62 & 90.05 & 91.26 & 92.31 & 92.92 \\
\hline $1 \mathrm{H}-3,1-3$ & 0.00 & 0.00 & 1.80 & 13.70 & 32.70 & 54.79 & 68.82 & 77.27 & 82.01 & 84.14 & 85.72 & 87.36 & 88.39 & 89.61 & 90.40 & 91.19 & 92.16 & 92.95 & 94.11 \\
\hline $1 \mathrm{H}-5,48-50$ & - & - & - & - & 0.15 & 0.95 & 6.84 & 24.21 & 48.18 & 64.45 & 72.34 & 76.83 & 79.43 & 81.63 & 83.92 & 85.92 & 87.72 & 89.42 & 90.91 \\
\hline $1 \mathrm{H}-5,52-54$ & - & - & - & - & 2.61 & 9.33 & 33.19 & 61.73 & 77.70 & 83.74 & 86.37 & 88.22 & 89.48 & 91.04 & 92.21 & 93.09 & 94.45 & 95.23 & 95.81 \\
\hline $2 \mathrm{H}-2,74-76$ & - & - & - & - & 2.61 & 5.14 & 15.27 & 36.99 & 57.34 & 68.25 & 73.90 & 77.50 & 79.74 & 81.98 & 83.93 & 85.78 & 87.63 & 89.19 & 90.94 \\
\hline $2 \mathrm{H}-2,76-79$ & - & - & - & - & 2.29 & 9.81 & 32.68 & 58.77 & 74.89 & 81.44 & 84.17 & 85.93 & 87.30 & 88.86 & 90.03 & 91.30 & 93.55 & 94.82 & 95.99 \\
\hline $2 \mathrm{H}-2,79-81$ & - & - & - & - & 5.70 & 16.17 & 40.31 & 63.32 & 75.58 & 80.86 & 83.31 & 85.29 & 86.61 & $\begin{array}{l}80.00 \\
88.12\end{array}$ & 89.34 & 90.76 & 92.17 & 93.40 & 95.00 \\
\hline $2 \mathrm{H}-4,8-10$ & 二 & 二 & 二 & 二 & 0.93 & $\begin{array}{r}1.17 \\
4.89\end{array}$ & 16.98 & 36.69 & 54.03 & $\begin{array}{l}63.54 \\
63.54\end{array}$ & $\begin{array}{l}0.31 \\
68.30\end{array}$ & 71.86 & 74.44 & $\begin{array}{l}77.02 \\
77.12\end{array}$ & 79.10 & 81.47 & 83.75 & 85.73 & 87.91 \\
\hline $2 \mathrm{H}-4,12-15$ & 二 & 二 & 二 & 二 & 3.50 & 10.16 & 33.80 & 62.08 & 77.90 & 83.88 & 86.49 & 88.32 & 89.58 & 91.12 & 92.28 & $\begin{array}{l}03.15 \\
93.15\end{array}$ & 94.50 & $\begin{array}{l}05.27 \\
95.27\end{array}$ & $\begin{array}{l}01.81 \\
95.85\end{array}$ \\
\hline $2 \mathrm{H}-4,17-19$ & 二 & - & 二 & 二 & $\begin{array}{l}5.50 \\
1.52\end{array}$ & $\begin{array}{r}1.10 \\
7.13\end{array}$ & 20.33 & 40. & 56.47 & $\begin{array}{l}64.55 \\
64.80\end{array}$ & $\begin{array}{l}80.49 \\
68.58\end{array}$ & $\begin{array}{l}71.83 \\
71.83\end{array}$ & $\begin{array}{l}79.58 \\
74.49\end{array}$ & $\begin{array}{l}76.12 \\
76.76\end{array}$ & $\begin{array}{l}79.28 \\
79.32\end{array}$ & 81.68 & $\begin{array}{l}8.50 \\
83.95\end{array}$ & 86.11 & 88.87 \\
\hline $3 \mathrm{H}-7,2-4$ & - & - & - & - & 2.60 & 10.10 & 27.8 & 48.2 & 62.31 & 69.90 & 73.6 & 76.43 & 78.18 & 80.23 & 82.37 & $\begin{array}{l}03.93 \\
83.93\end{array}$ & 85.78 & 87.44 & $\begin{array}{l}80.01 \\
88.90\end{array}$ \\
\hline $3 \mathrm{H}-7,5-$ & - & - & - & - & 3.95 & 10.58 & 27.6 & 50. & 66.5 & 75. & 79. & 81.94 & 84.06 & 85.78 & 87.42 & 88.86 & 90.40 & 91.74 & 92.89 \\
\hline & - & - & - & - & 3.79 & 11.87 & 35.44 & 62. & 78.83 & 85.57 & 88. & 89. & 90.96 & 92.11 & 93.07 & 94.23 & 95.09 & 95.48 & $\begin{array}{l}92.89 \\
96.25\end{array}$ \\
\hline $4 \mathrm{H}-3,39-41$ & 0.00 & 4.40 & 19.00 & 47.80 & 66.60 & 79.40 & 86.14 & 89.22 & 91.31 & 92.72 & 93.39 & 94.33 & 95.17 & 95.65 & 96. & 96.50 & 97.35 & $\begin{array}{l}97.40 \\
97.40\end{array}$ & 97.57 \\
\hline $4 \mathrm{H}-3,96-98$ & 13.70 & 23.70 & 41.50 & 54.70 & 60.60 & 65.20 & 66. & 68.98 & 72.47 & 76.22 & 79.04 & 81.52 & 83.27 & 84.83 & 86.38 & 87.98 & 89.46 & 90.87 & \\
\hline $4 \mathrm{H}-4,61-63$ & & & & - & 7.13 & 13.54 & 36. & 63.50 & 78.73 & 84.49 & 87.00 & 88.76 & 89.97 & 91.46 & 92.57 & 93.41 & 94.71 & 95.45 & 96.01 \\
\hline $4 \mathrm{H}-5,48-50$ & 0.00 & 0.30 & 1.80 & 8.00 & 18.20 & 38.16 & 61. & 76. & 83.30 & 86.40 & 88.11 & 89.67 & 90.52 & 91.61 & 92.54 & 93.40 & 94.64 & 95.18 & 95.65 \\
\hline $5 \mathrm{H}-1,45-47$ & & & & & 1.97 & 9.71 & 33.44 & 61.8 & 77.65 & 83.53 & 86.08 & 88.24 & 89.41 & 90.59 & 91.67 & 92.65 & 93.63 & 94.41 & 95.39 \\
\hline $5 \mathrm{H}-1,51-53$ & - & - & - & - & 0.98 & 4.25 & 19.99 & 46.23 & 66.93 & 76.73 & 80.69 & 83.46 & 84.85 & 86.43 & 87.92 & 89.40 & 90.69 & 91.88 & 93.07 \\
\hline $5 \mathrm{H}-1,55-58$ & 二 & 二 & 二 & 二 & 8.39 & 17.55 & 42.74 & 67.48 & 79.75 & 84.79 & 87.08 & $\begin{array}{l}83.40 \\
88.82\end{array}$ & $\begin{array}{l}89.83 \\
89.03\end{array}$ & $\begin{array}{l}91.02 \\
91.43\end{array}$ & 92.03 & 93.04 & 93.95 & 94.50 & 95.24 \\
\hline $5 \mathrm{H}-1,58-60$ & 二 & 二 & 二 & 二 & 7.46 & 13.85 & 36.52 & 63.63 & 78.81 & 84.55 & 87.04 & $\begin{array}{l}0.02 \\
88.80\end{array}$ & 90.01 & 91.49 & 92.60 & 93.43 & 94.73 & 95.47 & 96.02 \\
\hline $5 \mathrm{H}-2,64$ & 二 & 二 & 二 & 二 & $\begin{array}{l}.1 .40 \\
0.20\end{array}$ & 0.50 & 2.50 & $\begin{array}{r}0.03 \\
9.60\end{array}$ & 21.20 & 33.10 & $\begin{array}{l}01.04 \\
41.60\end{array}$ & $\begin{array}{l}0.00 \\
47.50\end{array}$ & 52.10 & $\begin{array}{l}56.00 \\
56.00\end{array}$ & $\begin{array}{l}92.00 \\
6000\end{array}$ & 63.70 & 66.90 & $\begin{array}{l}70.10 \\
70.10\end{array}$ & 72.90 \\
\hline $5 \mathrm{H}-2,64$ & - & - & - & - & 0.20 & 0. & 3.5 & 14. & 32.70 & 47.20 & 55.70 & 61.00 & 64.70 & 67.90 & 71.10 & 73.90 & 76.60 & 79.00 & 81.20 \\
\hline $5 \mathrm{H}-2,64$ & - & - & - & - & 0.0 & 0. & 8.4 & 38. & 62.12 & 69.41 & 70.00 & & & & & 15.90 & & & \\
\hline & - & - & - & - & 0.7 & 4.4 & 14.7 & 35. & 56. & 67. & 72. & 76 & 78 & 80.6 & 82. & 84.62 & 86 & 88.09 & 89.48 \\
\hline & - & - & - & - & 2. & 7. & 23. & 46 & 64 & 73 & 78 & & & & $\begin{array}{l}82.03 \\
86.59\end{array}$ & $\begin{array}{l}8+.02 \\
88.45\end{array}$ & 89.92 & $\begin{array}{l}00.39 \\
91.38\end{array}$ & 91.87 \\
\hline $5 \mathrm{H}-5,102-104$ & 5.10 & 10.60 & 20.10 & 33.00 & 43.10 & 53.40 & 64.01 & 74.12 & 81.34 & 85.14 & 87.30 & 88.83 & 90.15 & 91.52 & 92.31 & $\begin{array}{l}0.40 \\
93.20\end{array}$ & 94.04 & 94.89 & 95.42 \\
\hline
\end{tabular}

Notes: $-=$ not determined. $[\mathrm{f}]=$ fine laminae in $T_{d}$ division; $[\mathrm{m}]=$ medium laminae in $T_{d}$ division; $[c]$ = coarse laminae in $T_{d}$ division.

This table also appears on CD-ROM. 

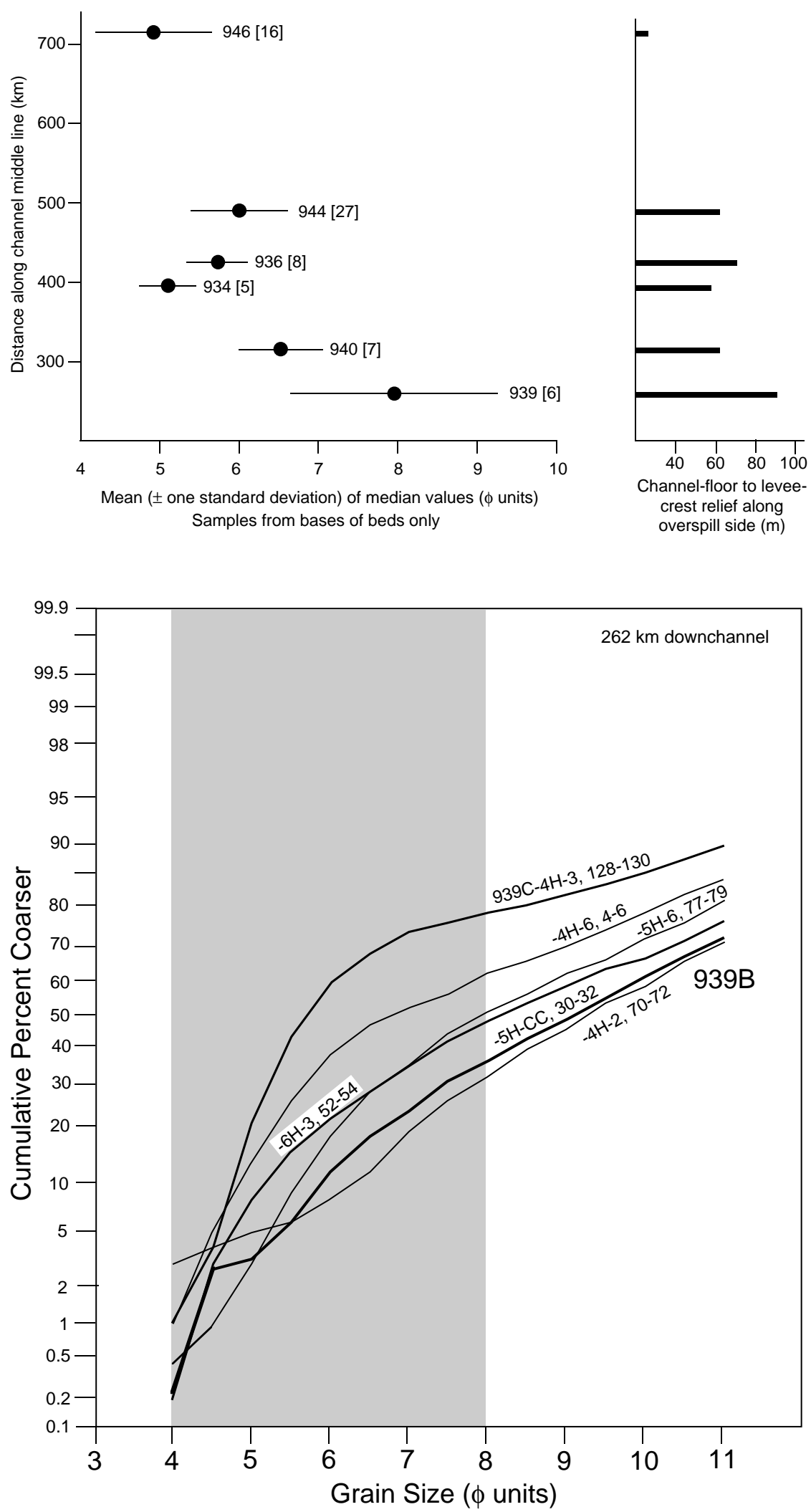

Figure 9. Comparison of the median size of basal samples from overspill turbidites with downchannel distance and modern levee height along the Amazon Channel.
Figure 10. Cumulative grain-size curves, probability ordinate, for five samples from Hole 939B and one from Hole 939C. Silt size classes are shaded. 
A
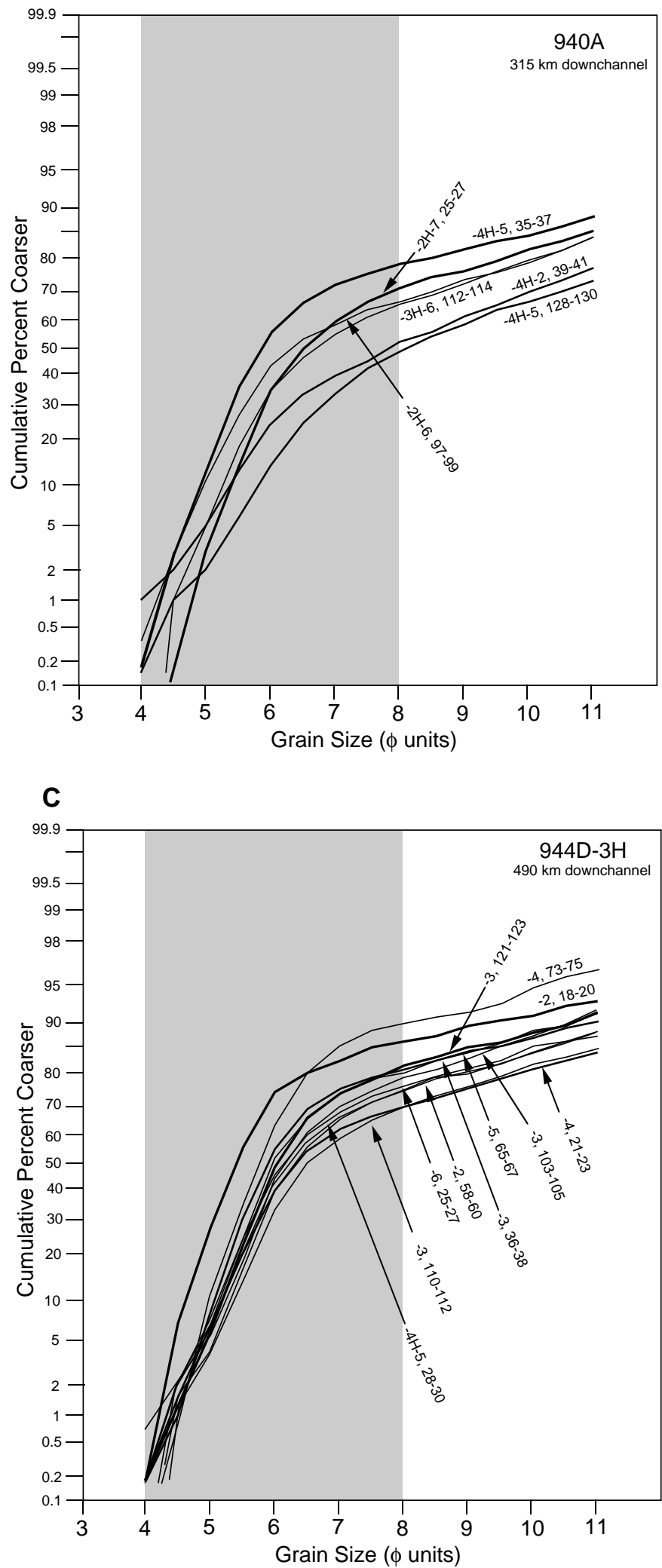

B

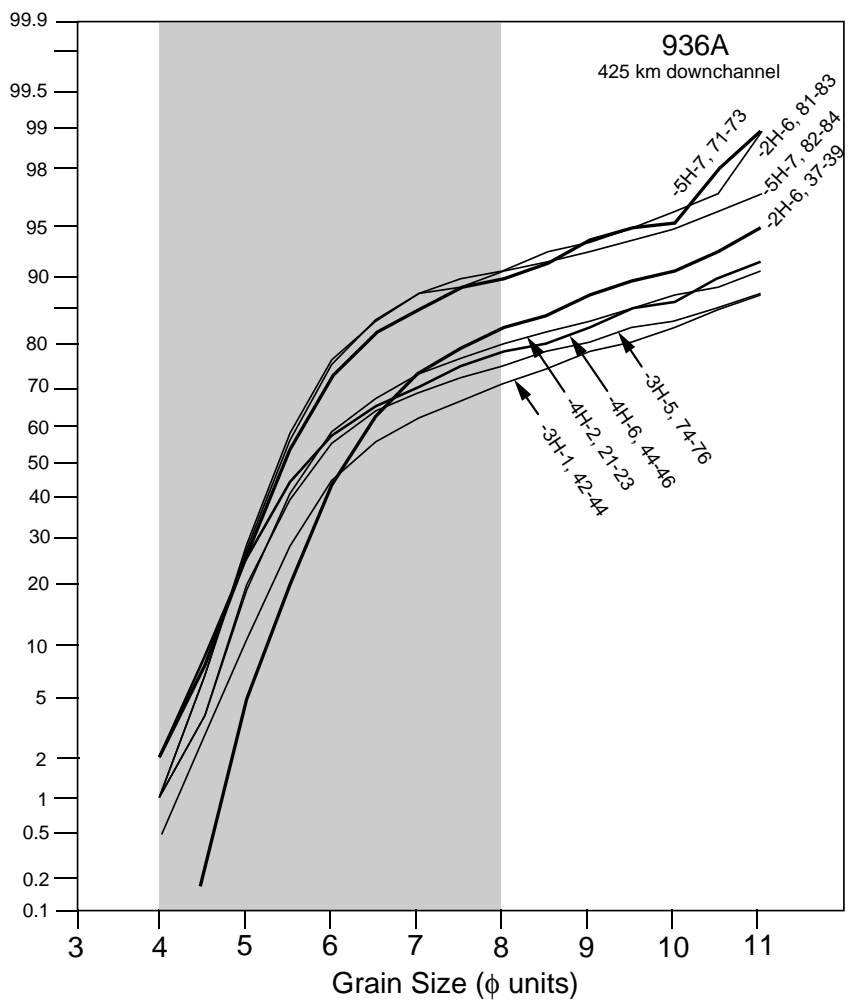

Figure 11. Cumulative grain-size curves for middle fan sites, probability ordinate. A. Samples from Cores 155-940A-2H through $4 \mathrm{H}$. B. Samples from Cores 155-936A-2H through 5H. C. Samples from Core 155-944D-3H except one sample from Core 4H. 

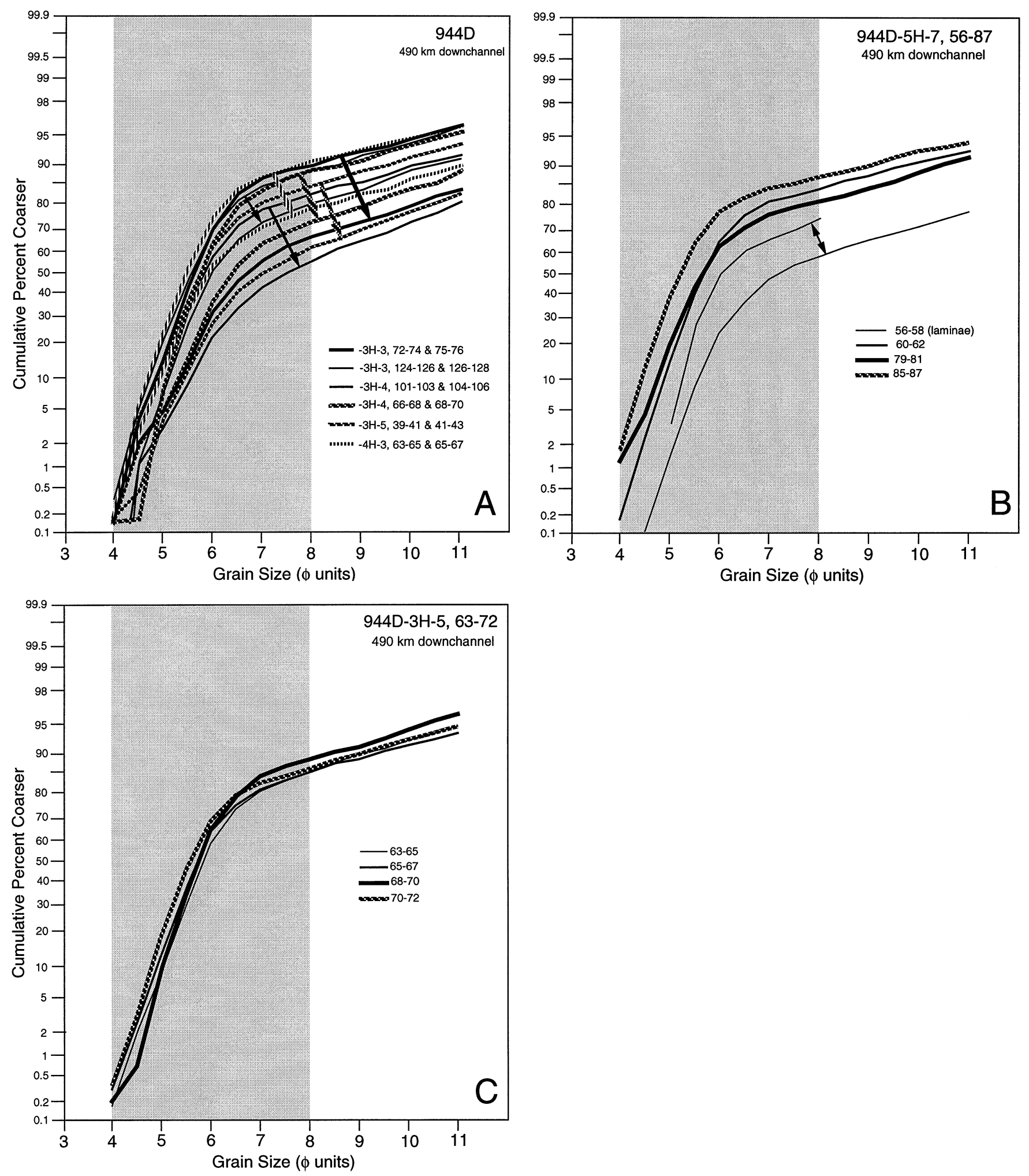

Figure 12. Cumulative grain-size curves for multiply sampled spillover turbidites at Site 944, probability ordinate. A. Pairs of samples from the base and middle of turbidites in Cores 155-944D-3H and 4H. Pattern-coded arrows connect curves for coarser basal samples with curves for finer overlying samples in each bed. B. Five samples from a single 30-cm-thick turbidite, with heavier weight curves for deeper samples. Two curves from the bed top (155-944D-5H-7, 56-58 cm) are from separate samples of silt laminae. C. Four samples from the base (thick curves) to the top (thin curve) of a 10-cm-thick turbidite. Note the absence of grading. 
Figure 13. Cumulative grain-size curves, probability ordinate, showing the contrast between silt laminae and mud laminae of $T_{d}$ divisions of single spillover turbidites. Pattern-coded arrows connect curves for samples from the same bed. Silt size classes are shaded.

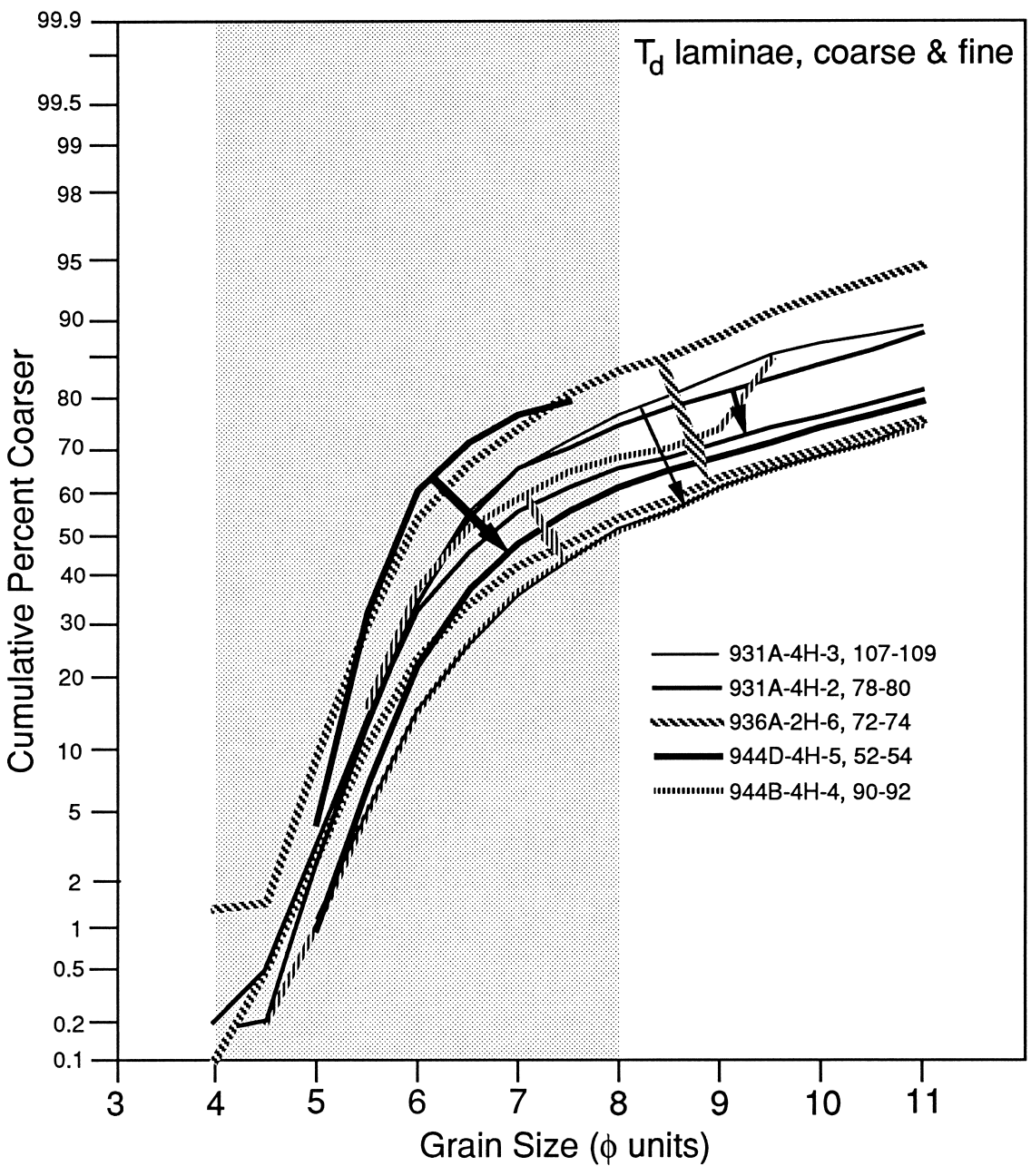

A
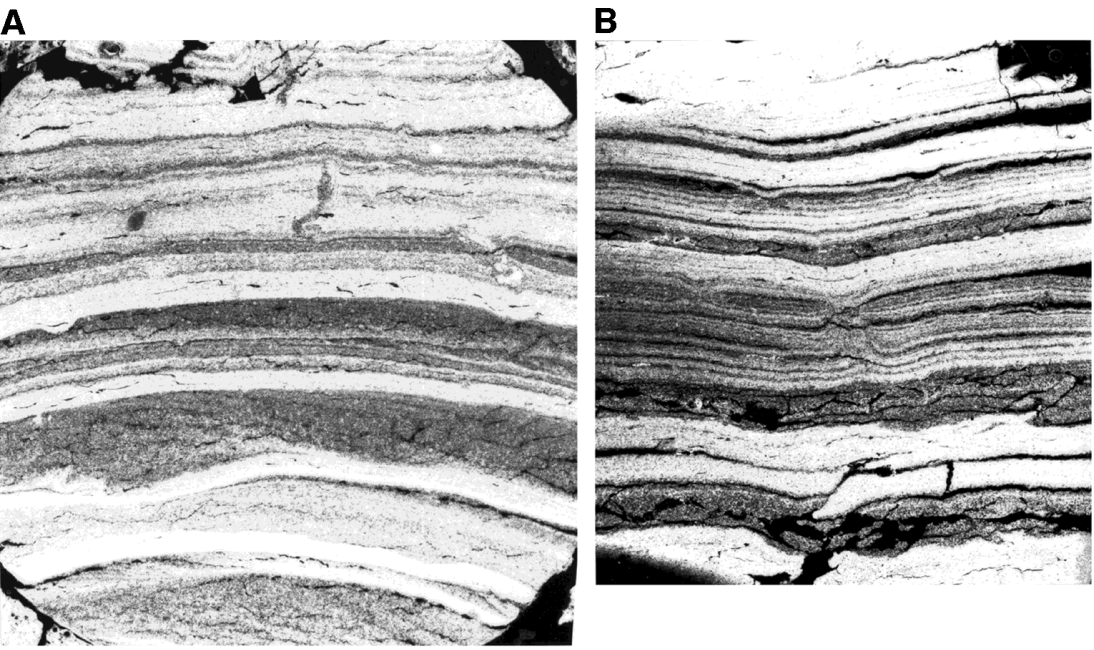

Figure 14. Prints made directly from thin sections, showing delicate lamination and marked separation of silt (gray) and mud (white) in $\mathrm{T}_{\mathrm{d}}$ divisions of spillover turbidites. A. Sample 155-931A-4H-2, 78-80 cm. B. Sample 155-944B-5H-3, 49-51 cm. Different silt laminae show sharp bases, sharp tops, microcross-lamination (lower of two thick laminae in A), inverse grading (upper of two thick laminae in $\mathrm{A}$ ), and normal grading (middle of B). Each image shows a 1.5-cm-thick interval.

pycnal flow directly from the river mouth onto the fan (see also Damuth and Kumar, 1975), which would require high suspended sediment concentrations in turbidity currents and prompt flocculation of silt- and clay-sized particles. Given these observations, it seems highly unlikely that the more poorly sorted subpopulation of fine silt and clay represents the primary particle-size distribution in the Amazon Channel turbidity currents. Instead, much of this mud was probably in the form of low-density, silt-sized floccules. This suspended load would therefore have had a size distribution closer in shape to a lognormal distribution with a single mode, and without the prominent "kink" shown by our grain-size plots. It is for this reason that we use the median as a measure of central tendency in this paper: the mean would give a false impression of the texture of the suspended load during turbidity current transport.

If it is true that some part of the primary load of the turbidity currents consisted of floccules, then magnetic-particle alignments might 
A

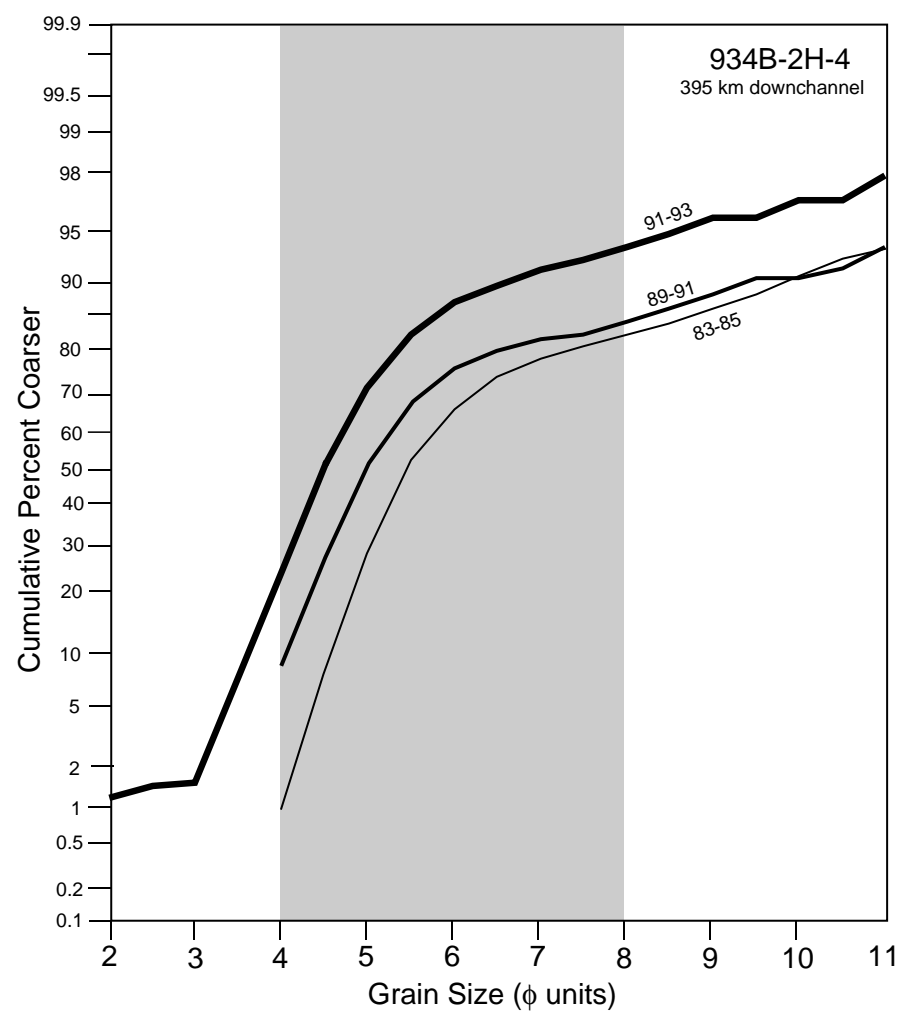

B

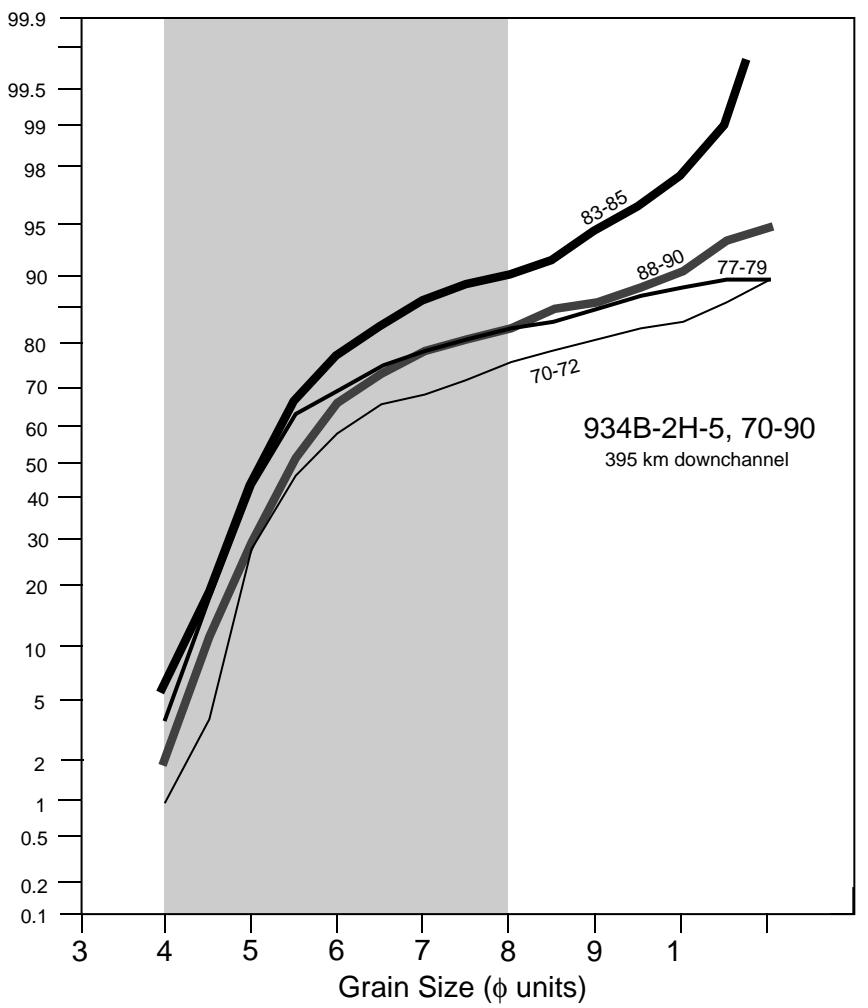

Figure 15. Cumulative grain-size curves for multiply sampled spillover turbidites at Site 934, probability ordinate. The thickest curves correspond to the deepest samples in each bed. A. Three samples from a normally graded 10-cm-thick bed. B. Four samples from an inverse- to-normal-graded, 20-cm-thick bed. The basal sample has a patterned curve and is finer grained than all but the uppermost sample.

have become somewhat degraded by collapse of the floccules during compaction, as proposed by Ellwood (1979).

\section{The Elusiveness of Primary Textural Characteristics}

The fine silt through clay texture determined in the laboratory likely does not reflect the true texture of the finer part of the suspended load of the turbidity currents. To rationalize the results from wet sieving, the Sedigraph, and shipboard physical-properties measurements, we based our size calculations on a high average grain density of $2.79 \mathrm{~g} / \mathrm{cm}^{3}$, even though the actual grain population is heterogeneous in mineralogy and density. Smear-slide analyses (Flood, Piper, Klaus, et al., 1995) indicate that the turbidity currents contained significant quantities of heavy minerals with densities commonly as high as $3.5 \mathrm{~g} / \mathrm{cm}^{3}$, but they also carried abundant quartz and feldspar grains (density about $2.65 \mathrm{~g} / \mathrm{cm}^{3}$ ).

We might have converted the Sedigraph data to settling-velocity data to circumvent the issue of mixed mineral densities in the samples (settling velocity is what the Sedigraph actually measures, but not what its associated software reports). However, the true settling velocities in a turbidity current depend on salinity, density and viscosity of seawater at 3000-4000 m depth, and on the concentration in the flow itself (Pirmez, 1994, p. 412-413). We have therefore decided that the simplest way to present the raw, uninterpreted data is as the equivalent size of $2.79 \mathrm{~g} / \mathrm{cm}^{3}$ spheres, using the average grain density from physical-properties measurements. Conversion of the raw data to settling velocities would provide no remedy for the fact that fine silt through clay was probably in the form of larger low-density particles in the turbidity currents. These floccules would settle more quickly than their component grains, but shear within the current, particularly near the base of the flow, is widely believed to modify the degree of flocculation and size of floccules (Stow and Bowen, 1980).

In spite of all the difficulties associated with specification of the primary texture of the suspended load of the overspilling turbidity currents of Amazon Channel, we can safely make the following generalizations:

1. The load of the turbidity currents was well sorted to moderately well sorted, predominantly silt.

2. From the upper fan to the lower fan, the median size of spillover turbidites increases as levee height decreases.

3. The overall downfan increase in median size results from overspill farther up the fan preferentially depleting the flows in fine particles.

4. At sites having anomalously low levee height (e.g., Site 934), spillover turbidites are thicker and coarser grained than at nearby sites on high levees, suggesting a vertical textural grading within each turbidity current (Stacey and Bowen, 1988; Hiscott, 1994).

5. Much of the fine silt and clay was probably in the form of particle aggregates or floccules.

\section{DISCUSSION}

The counteracting effects of turbidity-current inflation by seawater entrainment and continual loss of suspension by overspill are fundamental controls on levee facies, texture of spillover turbidites, and channel cross-sectional area. Because of the major decline in flow volume and sediment load while transiting the Amazon Channel, discharge and channel cross-sectional areas are dramatically re- 
A

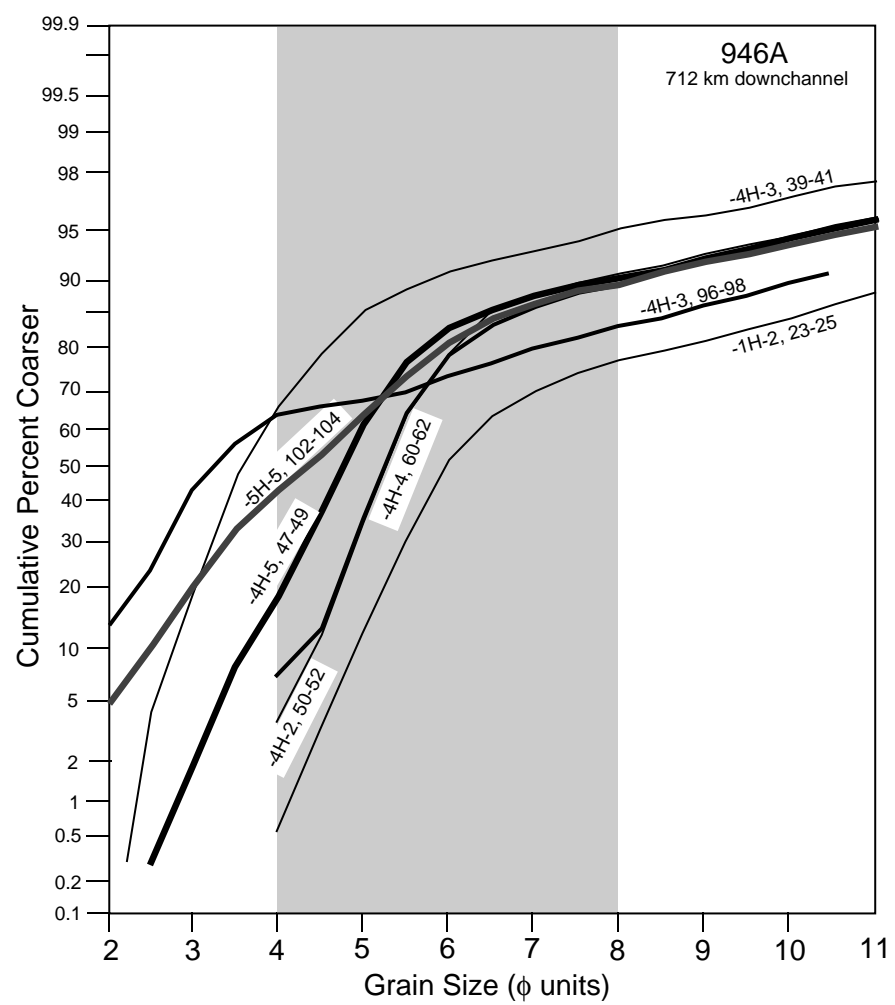

B

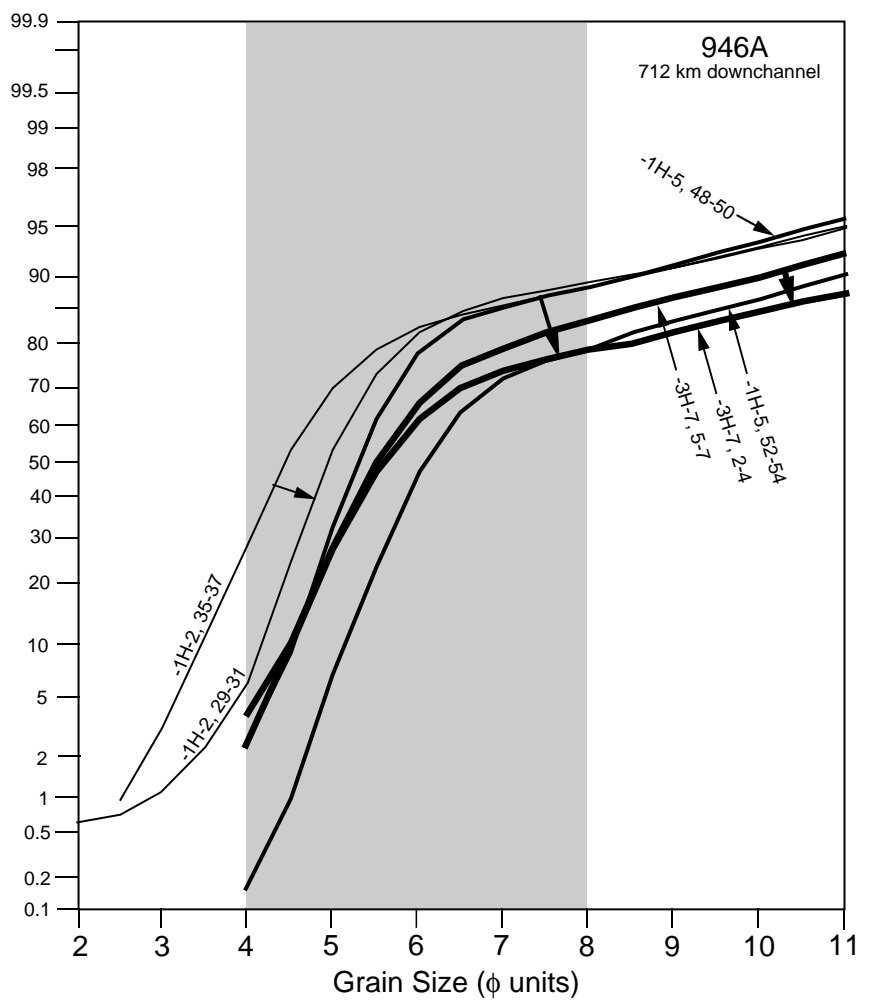

Figure 16. Cumulative grain-size curves for sandy lower fan spillover turbidites at Site 946, probability ordinate. A. Texture of seven samples from Cores 155946A-1H through $5 \mathrm{H}$. B. Normal grading shown by pairs of samples from single spillover turbidites. Arrows connect curves from the same bed.

duced on the lower fan. However, the material that makes it as far as the lower fan is enriched in sand (Damuth and Kumar, 1975) because finer particles have been preferentially left upfan, contributing to levee growth.

Both the talweg centerline slope and flow depth decrease down the Amazon Channel. The body of a long turbidity current transiting the channel would therefore be moving more slowly near its front than near its tail (see Equation 1). Hence, a turbidity current confined within the channel might replenish its suspended load by becoming shorter, as its tail catches up with its decelerating front.

The samples analyzed for this study represent the coarsest spillover deposits at each site. A greater proportion of the sediment within Amazon Channel levees is made up of color-banded mud turbidites. These may represent overspill from turbidity currents that were carrying little or no sand and silt. Alternatively, only material from the very dilute top of a flow with a mixed sand-through-mud load may have escaped from the channel, even though the same flow may have spilled silt and sand load over the levees elsewhere because of different channel geometry or levee heights. We tentatively favor the latter interpretation, mainly because of differences in the proportions of sand and silt at Site 934 compared to Sites 940 and 936 (Fig. 2). We believe that the same flows that deposited silt and sand turbidites at Site 934 only left a record of laminated muds at the other two sites, because the higher levees at these other sites restricted overspill to the dilute tops of flows transiting the main channel.

The hypothesis that levee height is an important control on grain size of spillover turbidites is supported by the general fining upward observed in all levee successions cored during Leg 155 (Fig. 2; Flood, Piper, Klaus, et al., 1995). Specifically, as levees grow in height, they prevent the overspill of the coarser load of turbidity currents. The very highest levees allow no coarse silt and sand overspill (e.g., Site 939; Fig. 2), whereas lower levees are unable to prevent sand overspill (e.g., Sites 934 and 946; Figs. 2, 9).

The occurrence of thick and well-developed silt and mud laminae of turbidite division $\mathrm{T}_{d}$ (Fig. 5) is consistent with overspill from turbidity currents that were only just capable of overtopping the levees of the Amazon Channel, but that were carrying a mixed silt and mud load. We invoke fluctuations of flow depth in the main channel, perhaps as a result of passage of interfacial Helmholtz waves down the channel, as a mechanism to explain the well-developed silt-mud laminae. At times when the flow top was at a wave crest, overspill of silt load would be accentuated, and as an interfacial wave trough passed in the adjacent main channel, overspill of silt would cease, allowing deposition of a mud lamina. It is noteworthy that similar thick siltmud laminae characterize spillover turbidites of NAMOC in the Labrador Sea (Hiscott et al., 1989), suggesting that this type of $T_{d}$ division may be characteristic of levee deposits (see also Piper and Deptuck, this volume).

What might be the character of a typical turbidity current that deposited the silt beds sampled along the Amazon Channel? It has been suggested by Normark and Piper (1991) that thick muddy turbidity currents or a series of mud-rich flows are most likely to construct levees, whereas thinner sand-rich flows are more likely to account for middle- or lower-fan sand lobes and sheets. The Amazon Fan has both morphological elements (Damuth and Kumar, 1975), but neither velocity calculations nor reasonable models of the vertical structure of turbidity currents require two fundamentally different types of flow. Instead, our results are consistent with mixed-load flows carrying sand deep in the channel and spilling silt and mud over high levee crests, except where low levees allowed overspill of the sand load as well. Formation of lower-fan and sub-levee sand sheets (high-amplitude reflection packets, or HARPs) is discussed elsewhere (Pirmez et 
A

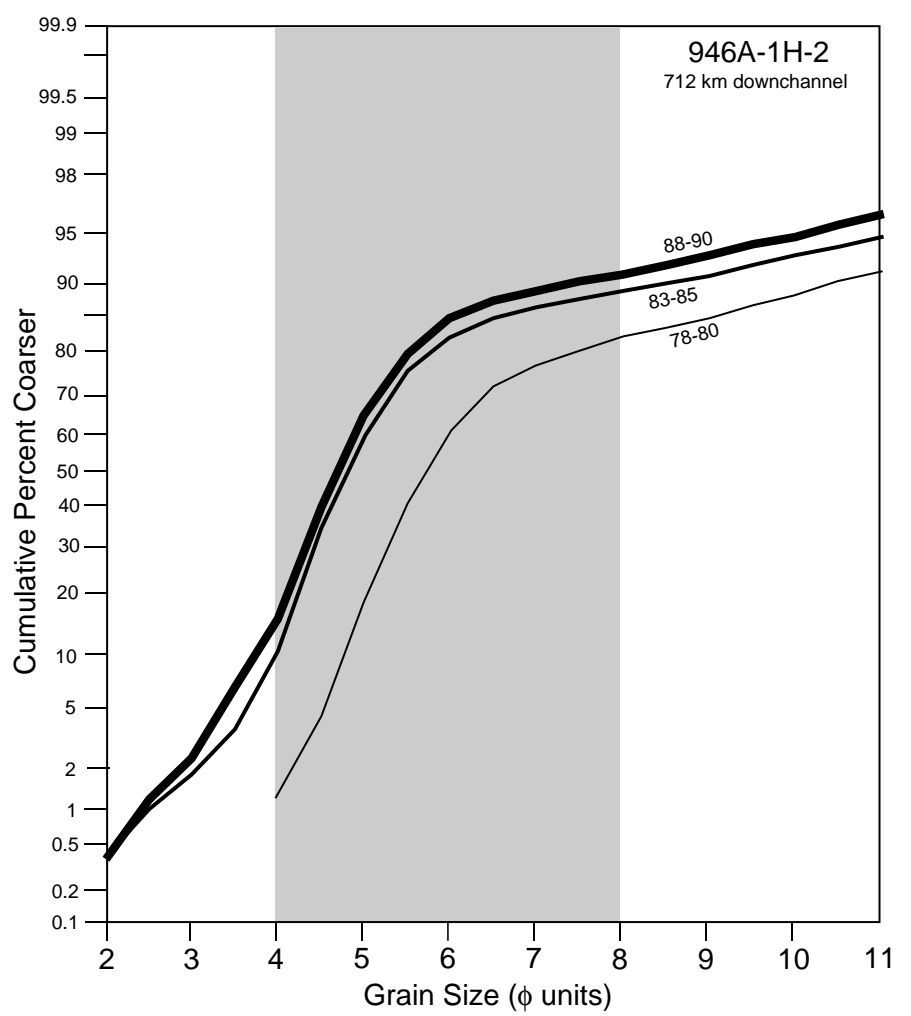

B

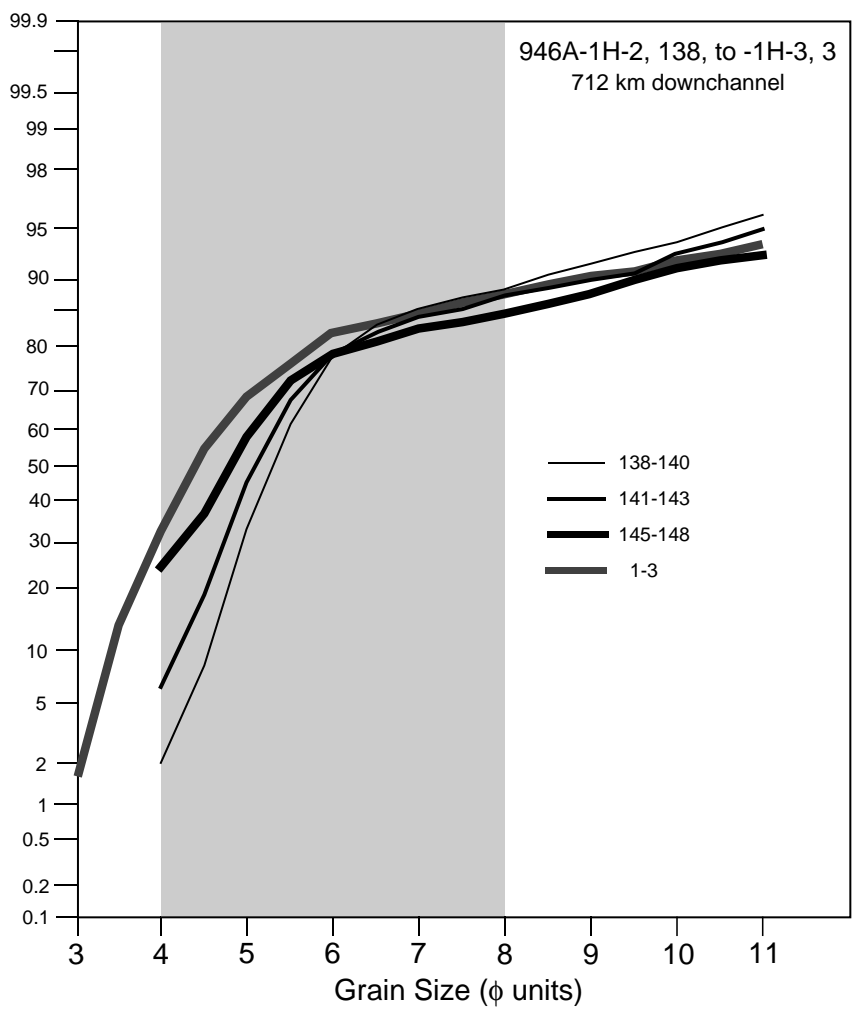

Figure 17. Cumulative grain-size curves for multiply sampled and normally graded spillover turbidites at Site 946 , probability ordinate. A. Three samples from a 10-cm-thick bed (interval 155-946A-1H-2, 78-90 cm). The line weight is heaviest for the basal sample, and lightest for the uppermost sample. B. Four samples from the base to the top of a 15 -cm-thick spillover turbidite. The fractions coarser than the 6 - $\phi$ kink in all profiles are finer with height above the base of the bed, but all samples have essentially the same distribution of fines to the right of the kink.

al., this volume), and likely involves a multistep transfer of sand down the fan as a consequence of repeated episodes of avulsion and talweg incision.

The suggestion that the same turbidity currents carried sand along the talweg and spilled silt and mud onto the levees is supported by independent velocity estimates of Pirmez (1994), using differential levee heights around the channel bends, and the texture of channel sands. On the middle and lower fan, levee heights suggest velocities of $0.5-2.0 \mathrm{~m} / \mathrm{s}$, and the grain sizes of channel deposits suggest velocities of $0.3-1.0 \mathrm{~m} / \mathrm{s}$. These estimates overlap, suggesting that the type of current responsible for the meandering planform of the channel was also competent to carry sand along the talweg.

Both the concentration and average grain size of the suspended load decrease from the base to the top of a turbidity current (Middleton and Hampton, 1973; Stacey and Bowen, 1988; Hiscott, 1994). To put the characteristics of turbidity currents transiting the Amazon Channel in context, we relate some observations in the vicinity of Sites 934 and 936 to a graphical representation (Fig. 18A) of the diffusion model of Rouse (1937) for relative sediment concentration, plotted in terms of the dimensionless variable $z$, where

$$
z=w /\left(\beta \kappa u_{*}\right)
$$

where $w=$ particle settling velocity, $\beta=$ a coefficient relating the sediment diffusion to the diffusion of turbulent energy $(\beta \approx 1), \kappa=$ the von Kármán constant $(\kappa \approx 0.3$ for a low-concentration turbidity current), and $u_{*}=$ shear velocity of the current. $C_{a}$ in Figure $18 \mathrm{~A}$ is the concentration at a reference level, $a$, near the bed, and $C$ is the concentration at other levels in the flow, for each grain size of the suspended load, where grain size is expressed by a settling velocity.

The flow top in the Rouse graph, developed for open-channel flows in river channels, likely corresponds to a height somewhat above the velocity maximum in turbidity currents, above which sediment concentration drops off rapidly (Middleton and Hampton, 1973; Stacey and Bowen, 1988; Fig. 18B).

Suppose that flows passing Sites 934 and 936 had maximum velocities of about $2 \mathrm{~m} / \mathrm{s}$ (Pirmez, 1994). From standard fluid mechanical relationships, if $f_{o}+f_{i}=0.01$, then $u_{*}=u / 28=7 \mathrm{~cm} / \mathrm{s}$. The $2-\mathrm{mm}$ $(-1 \phi)$ quartz grains observed in the abandoned channel deposits at Site 934 (and assumed to be similar in size to the coarsest sediment in the talweg of the Amazon Channel) could not have been transported in suspension by such flows, because a conservative suspension criterion of $u_{*}=w$ (Middleton, 1976) would require $u_{*}=26 \mathrm{~cm} / \mathrm{s}$, significantly higher than the estimate of $7 \mathrm{~cm} / \mathrm{s}$ based on differential levee heights. No grains coarser than about $0.6 \mathrm{~mm}$ can be carried in suspension by a flow with a mean velocity of $2 \mathrm{~m} / \mathrm{s}$.

If $u_{*}=7 \mathrm{~cm} / \mathrm{s}$, then grains with settling velocities of $5.2 \mathrm{~cm} / \mathrm{s}$ and $1.1 \mathrm{~cm} / \mathrm{s}$ would have $z$ values of 2.5 and 0.52 . These $z$ values are plotted as solid circles on Figure 18A at appropriate overspill depths for Sites 934 and 936 . The circle that corresponds to the height of the hanging valley at Site 934 leads to a prediction that the relative concentration of $2 \phi$ sand at the base of a turbidity current spilling into the hanging valley would be essentially nil. As predicted, $2 \phi$ sand is rare at this site (Fig. 15). The circle that corresponds to the height of the levee crest at Site 936 suggests a relative concentration of about $10 \%$ for $3 \phi$ sand in the lower part of the overspilling current. Grains with $z$ values approaching $0.8($ diameter $=2.5 \phi)$ might also be ex- 

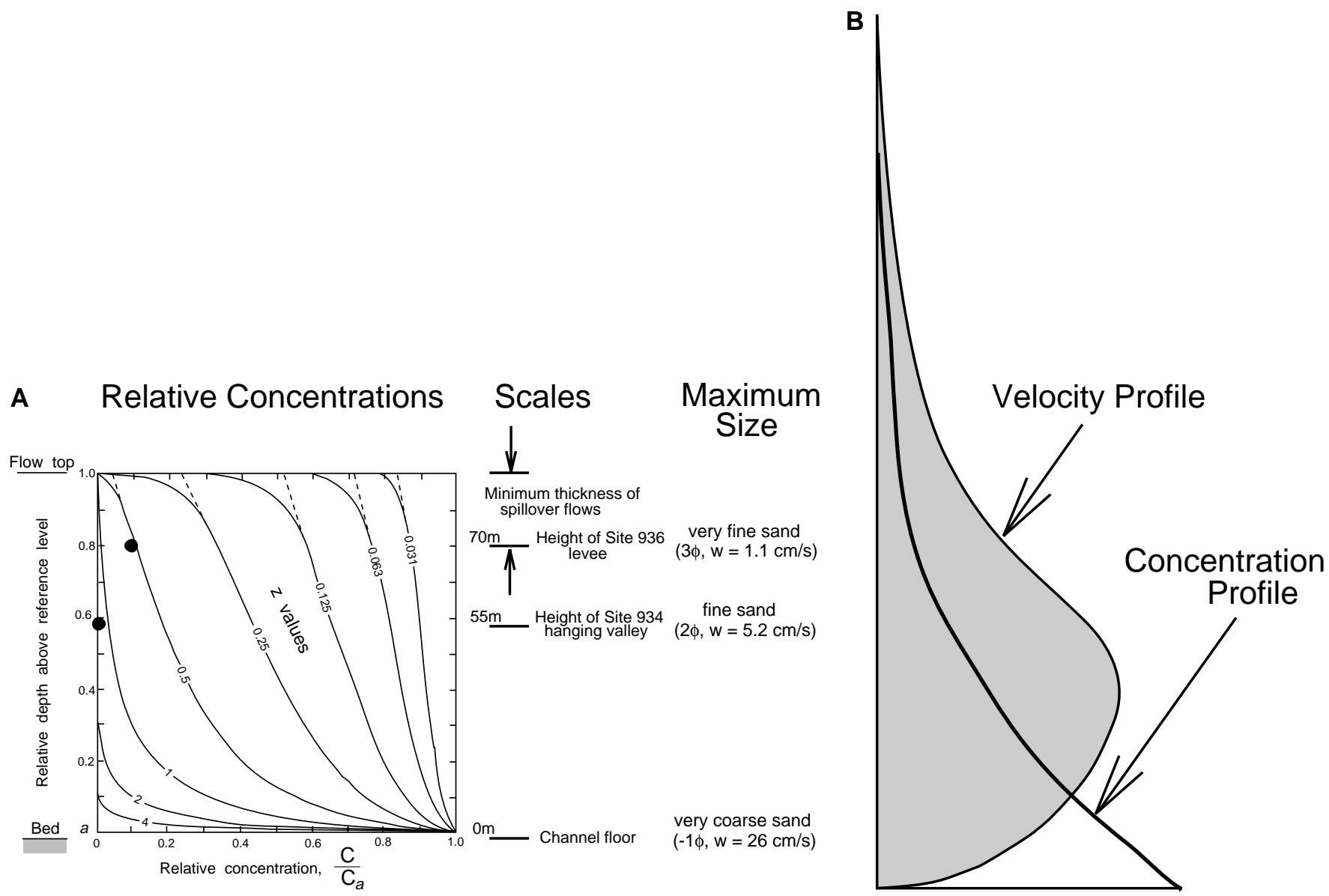

Figure 18. A. Suspension model for open-channel flow conditions in rivers or laboratory flumes (Rouse, 1937), compared with the scale of Amazon Channel levees, maximum grain size of overspill deposits at Sites 934 and 936 . B. Theoretical velocity and concentration profiles of turbidity currents (Stacey and Bowen, 1988). The dashed lines near the flow top in (A) are approximate changes in curve shapes to make the suspension model appropriate to turbidity currents. Turbidity currents have a low-concentration wake behind the head (upper part of B) that is well above the velocity maximum and that has no equivalent in open-channel flows, where the velocity maximum is at the flow top. Reported settling velocities $(w)$ are determined using the Gibbs et al. (1971) empirical settling law, deep-ocean viscosity of $1.537 \times 10^{-2} \mathrm{~g} / \mathrm{cm} \cdot \mathrm{s}$ (Stanley and Batten, 1969) and density of $1.043 \mathrm{~g} / \mathrm{cm}^{3}$, a grain density of $2.79 \mathrm{~g} / \mathrm{cm}^{3}$ for data determined by Sedigraph $(2 \phi$ and $3 \phi)$, and a grain density of $2.65 \mathrm{~g} / \mathrm{cm}^{3}$ for very coarse quartz sand in the channel talweg.

pected in these overspilling currents. Extrapolation of grain-size profiles for samples from Site 936 suggests that $3 \phi$ sand is indeed present in some turbidites (Fig. 11B).

\section{CONCLUSIONS}

Based on samples taken from the coarsest spillover turbidites in the upper 10-50 m of the levees of the Amazon Channel, we conclude that flows that transported sand as bedload along the channel talweg were also responsible for the construction of levees and emplacement of graded coarse silt and very fine sand turbidites on the backsides of the levees. Starting on the upper fan, entrainment of seawater results in flow thickening to greater than bankfull depth, driving semicontinuous overspill along the full length of the channel. Flow concentration is maintained, in spite of entrainment, by preferential loss of the dilute tops of turbidity currents by repeated overspill, and possibly by flow shortening as turbidity currents transit the channel. Loss of suspension contributes to levee growth and is compensated for by a thirtyfold decrease in channel cross-sectional area from the upper fan to the lower fan.

The overspilling fraction of turbidity currents experiences a dramatic change in slope from about $0.3^{\circ}$ along the main channel to $3^{\circ}-$ $5^{\circ}$ on the backside of the adjacent levee. Because of reduced flow thickness and lower average concentration of the overspill, this higher bottom slope on the backside of the levee probably does not result in an acceleration of the overspilling flows. Instead, velocity is believed to decrease, leading to deposition and levee aggradation.

Overspill is apparently focused along the outer bends of meanders and at saddles in the levee crests. AMS paleoflow directions have considerable scatter (Fig. 6), but are broadly away from the main channel axis and down the slope of the backside of the levees. A small number of anomalous AMS paleoflow results, nearly perpendicular to the backside slope of the levees, suggest that spillover flows may leave the main channel at one meander bend and then flow parallel to the main channel axis along interchannel lows. The sites considered in this study are not situated in such interchannel lows, and therefore do not contain a significant record of this process. Alternatively, these apparently anomalous paleoflow directions might result from an erroneous assumption that all magnetic-mineral alignments are parallel to the flow direction; flow-normal alignments may characterize a few samples.

AMS paleoflow directions vary from the base to the top of single spillover turbidites (Fig. 8). We interpret these swings in alignment to indicate that streamlines in decelerating turbidity currents mean- 
dered about the average flow direction, as proposed by Parkash and Middleton (1970).

Grain-size distributions are characterized by a well-sorted very fine sand to medium silt fraction, separated by a prominent kink on cumulative plots from a poorly sorted mud fraction. Based on (1) the observation of widespread clay flocculation on the modern Amazon shelf and (2) inferred high sediment concentrations near the base of depositing turbidity currents, we explain the segmented grain-size plots as an unavoidable artifact of sample preparation, during which primary mud floccules are disaggregated into their component grains. The original population, in our view, consisted mainly of a well-sorted to moderately well-sorted mixture of (1) mineral-density grains of very fine sand to medium silt and (2) silt-sized, low-density floccules. Consequently, the best indicator of bulk grain size is the median, which is not affected by uncertainties about the degree of flocculation of finer fractions. Mean size is an inappropriate statistic for these samples.

Median size varies directly with the present local levee height (Fig. 9), even though the samples were taken at some depth below the modern levee surface (Fig. 2). This strong relationship suggests that the relative heights of proximal to distal levees of the Amazon Channel were established early during levee growth, and that the coarseness of a spillover turbidite depends mainly on the extent to which the middle part of the flow contributes to the overspill (Fig. 18). Even with constant levee height at a single site, subtle variations in flow thickness, perhaps because of the passage of Helmhotz waves along the upper interface of the flow, can lead to fluctuations in the silt content of the overspill and to formation of thick silt and mud laminae (Fig. 5).

On the Amazon Fan, the long-distance flow of channelized turbidity currents is modulated by continuous seawater entrainment (causing flows to thicken), and overspill across levees that decrease in height downfan. The channel profile is graded, like mature rivers; meandering smooths any irregularities in downchannel slope. We envision a delicate balance between entrainment, overspill, flow concentration, flow discharge, and levee aggradation, as suggested more than 20 yr ago by Komar (1973). Flows that spill silt onto levees are competent to carry sand as bedload in the talweg of the main channel, and we therefore see no reason to propose different types of flow (1) for long-distance sand transport and (2) to provide silt and mud to growing levees. Instead, the narrow range of texture and bed thickness in Amazon Channel levees (Fig. 2; Flood, Piper, Klaus, et al., 1995) implies only a small variation in the characteristics of turbidity currents passing through the channel. The counterbalancing effects of seawater entrainment and overspill presumably subdued most primary differences in the characteristics of the Pleistocene turbidity currents, and sorted the suspended load to achieve good size sorting at various levels in each flow. The upper part of each turbidity current was characterized by concentrations lower than the average for the flow (Fig. 18B), but still sufficiently high to ensure significant mud flocculation.

\section{ACKNOWLEDGMENTS}

This work was supported by a Natural Sciences and Engineering Research Council of Canada grant (OGP0006088) to RNH, and by JOI-USSSP grants to CP (155-20878b) and FRH (155-20846b). Acquisition and processing of multibeam bathymetry data (SeaBeam) was supported by NSF-OCE 82-14819 and JOI Inc. JSC1592. We thank the crew of SEDCO/BP 471 (JOIDES Resolution) for the successful drilling of Amazon Fan; Dr. Michael Fuller and Dr. Stanley Cisowski for use of the susceptibility system at University of California, Santa Barbara; and Helen Gillespie, Memorial University of Newfoundland, for completion of the grain-size analysis. Critical comments of reviewers B.B. Ellwood and P.D. Komar improved the content and organization of the paper.

\section{REFERENCES}

AmasSeds Research Group, 1990. A multidisciplinary Amazon Shelf sediment study. Eos, 71:1771.

Bagnold, R.A., and Barndorff-Nielsen, O., 1980. The pattern of natural size distributions. Sedimentology, 27:199-208.

Bouma, A.H., 1962. Sedimentology of Some Flysch Deposits: A Graphic Approach to Facies Interpretation: Amsterdam (Elsevier).

Chough, S., and Hesse, R., 1976. Submarine meandering thalweg and turbidity currents flowing for $4,000 \mathrm{~km}$ in the Northwest Atlantic Mid-Ocean Channel, Labrador Sea. Geology, 4:529-533.

Christiansen, C., Blæsild, P., and Dalsgaard, K., 1984. Re-interpreting "segmented" grain-size curves. Geol. Mag., 121:47-51.

Clark, J.D., Kenyon, N.H., and Pickering, K.T., 1992. Quantitative analysis of the geometry of submarine channels: implications for the classification of submarine fans. Geology, 20:633-636.

Clark, J.D., and Pickering, K.T., 1996. Architectural elements of submarine channels: application to hydrocarbon exploration. AAPG Bull., 80:194221.

Dade, W.B., Lister, J.R., and Huppert, H.E., 1994. Fine-sediment deposition from gravity surges on uniform slopes. J. Sediment. Res., A64:423-432.

Damuth, J.E., Kolla, V., Flood, R.D., Kowsmann, R.O., Monteiro, M.C., Gorini, M.A., Palma, J.J.C., and Belderson, R.H., 1983a. Distributary channel meandering and bifurcation patterns on Amazon deep-sea fan as revealed by long-range side-scan sonar (GLORIA). Geology, 11:94-98.

Damuth, J.E., Kowsmann, R.O., Flood, R.D., Belderson, R.H., and Gorini, M.A., 1983b. Age relationships of distributary channels on Amazon deep-sea fan: implications for fan growth pattern. Geology, 11:470-473.

Damuth, J.E., and Kumar, N., 1975. Amazon Cone: morphology, sediments, age, and growth pattern. Geol. Soc. Am. Bull., 86:863-878.

Ellwood, B.B., 1979. Particle flocculation: one possible control on the magnetization of deep-sea sediments. Geophys. Res. Lett., 6:237-240.

Flood, R.D., Kent, D.V., Shor, A.N., and Hall, F.R., 1984. The magnetic fabric of surficial deep-sea sediments in the HEBBLE area (Nova Scotian continental rise). Mar. Geol., 66:149-167.

Flood, R.D., Piper, D.J.W., Klaus, A., et al., 1995. Proc. ODP, Init. Repts., 155: College Station, TX (Ocean Drilling Program).

Folk, R.L., 1974. Petrology of Sedimentary Rocks: Austin, TX (Hemphill).

Gibbs, R.J., and Konwar, L., 1986. Coagulation and settling of Amazon River suspended sediment. Continental Shelf Res., 6:127-149.

Gibbs, R.J., Matthews, M.D., and Link, D.A., 1971. The relationship between sphere size and settling velocity. J. Sediment. Petrol., 41:7-18.

Hamilton, N., and Rees, A.I., 1970. The use of magnetic fabric in palaeocurrent estimation. In Runcorn, S.K. (Ed.), Palaeogeophysics: London (Academic Press), 445-464.

Hay, A.E., 1987. Turbidity currents and submarine channel formation in Rupert Inlet, British Columbia. 2. The roles of continuous and surge-type flow. J. Geophys. Res., 92:2883-2900.

Hesse, R., 1995. Long-distance correlation of spillover turbidites on the western levee of the Northwest Atlantic Mid-Ocean Channel (NAMOC), Labrador Sea. In Pickering, K.T., Hiscott, R.N., Kenyon, N.H., Ricci Lucchi, F., and Smith, R.D.A. (Eds.), Atlas of Deep Water Environments: Architectural Style in Turbidite Systems: London (Chapman and Hall), 276-281.

Hesse, R., and Chough, S.K., 1980. The Northwest Atlantic Mid-Ocean Channel of the Labrador Sea: II. Deposition of parallel laminated leveemuds from the viscous sublayer of low density turbidity currents. Sedimentology, 27:697-711.

Hiscott, R.N., 1994. Loss of capacity, not competence, as the fundamental process governing deposition from turbidity currents. J. Sediment. Res., A64:209-214.

Hiscott, R.N., Cremer, M., and Aksu, A.E., 1989. Evidence from sedimentary structures for processes of sediment transport and deposition during post-Miocene time at Sites 645, 646, and 647, Baffin Bay and the Labrador Sea. In Srivastava, S.P., Arthur, M.A., Clement, B., et al., Proc. ODP, Sci. Results, 105: College Station, TX (Ocean Drilling Program), 53-63.

Hiscott, R.N., and Middleton, G.V., 1980. Fabric of coarse deep-water sandstones, Tourelle Formation, Quebec, Canada. J. Sediment. Petrol., 50:703-722. 
Hrouda, F., 1982. Magnetic anisotropy of rocks and its application in geology and geophysics. Geophys. Surv., 5:37-82.

Kineke, G.C., Sternberg, R.W., Cacchione, D.A., Kranck, K., and Drake, D.E., 1991. Distribution and characteristics of suspended sediment on the Amazon Shelf. Oceanography, 4:21-26.

King, R.F., and Rees, A.I., 1962. The measurement of the anisotropy of magnetic susceptibility of rocks by the torque method. J. Geophys. Res., 67:1565-1572.

Komar, P.D., 1969. The channelized flow of turbidity currents with application to Monterey deep-sea fan channel. Geol. Soc. Am. Bull., 78:45444558.

, 1973. Continuity of turbidity current flow and systematic variations in deep-sea channel morphology. Geol. Soc. Am. Bull., 84:33293338.

Krumbein, W.C., 1934. Size frequency distributions of sediments. J. Sediment. Petrol., 4:65-77.

Ledbetter, M.T., and Ellwood, B.B., 1980. Spatial and temporal changes in bottom-water velocity and direction from analysis of particle size and alignment in deep-sea sediment. Mar. Geol., 38:245-261.

Manley, P.L., and Flood, R.D., 1988. Cyclic sediment deposition within Amazon deep-sea fan. AAPG Bull., 72:912-925.

McCave, I.N., 1981. Location of coastal accumulation of fine sediments around the southern North Sea. In Postma, H. (Ed.), Proceedings of the Workshop on Sediments and Pollutant Exchange. Rapp. Proces-Verbaux Reun. Cons. Int. Explor. Mer., 181:15-27.

Menard, H.W., 1955. Deep-sea channels, topography and sedimentation. AAPG Bull., 39:236-255.

Middleton, G.V., 1966. Experiments on density and turbidity currents: II. Uniform flow of density currents. Can. J. Earth Sci., 3:627-637. $84: 405-426$

Middleton, G.V., and Hampton, M.A., 1973. Sediment gravity flows: mechanics of flow and deposition. In Middleton, G.V., and Bouma, A.H. (Eds.), Turbidites and Deep Water Sedimentation. Short Course Notes, Soc. Econ. Paleontol. Mineral., Pacific. Sect., 1-38.

Nemec, W., 1988. The shape of the rose. Sediment. Geol., 59:149-152.

Normark, W.R., and Piper, D.J.W., 1991. Initiation processes and flow evolution of turbidity currents: implications for the depositional record. In Osborne, R.H. (Ed.), From Shoreline to Abyss: Contributions to Marine Geology in Honor of Francis Parker Shepard. Spec. Publ.-Soc. Econ. Paleontol. Mineral., 46:207-230.

O'Reilly, W., 1984. Rock and Mineral Magnetism: New York (Chapman and Hall).

Parkash, B., and Middleton, G.V., 1970. Downcurrent textural changes in Ordovician turbidite greywackes. Sedimentology, 14:259-293.
Piper, D.J.W., and Normark, W.R., 1983. Turbidite depositional patterns and flow characteristics, Navy Submarine Fan, California Borderland. Sedimentology, 30:681-694.

Pirmez, C., 1994. Growth of a submarine meandering channel-levee system on the Amazon Fan [Ph.D. thesis]. Columbia Univ., New York.

Pirmez, C., and Flood, R.D., 1995. Morphology and structure of Amazon Channel. In Flood, R.D., Piper, D.J.W., Klaus, A., et al., Proc. ODP, Init. Repts., 155: College Station, TX (Ocean Drilling Program), 23-45.

Rees, A.I., 1965. The use of anisotropy of magnetic susceptibility in the estimation of sedimentary fabric. Sedimentology, 4:257-271.

Rouse, H., 1937. Modern conceptions of the mechanics of turbulence. Am. Soc. Civ. Eng. Trans., 102:436-505.

Shor, A.N., Kent, D.V., and Flood, R.D., 1984. Contourite or turbidite? Magnetic fabric of fine-grained Quaternary sediments. In Stow, D.A.V., and Piper, D.J.W. (Eds.), Fine-Grained Sediments. Geol. Soc. Spec. Publ. London, 15:257-273.

Singer, J.K., Anderson, J.B., Ledbetter, M.T., McCave, I.N., Jones, K.P.N., and Wright, R., 1988. An assessment of analytical techniques for the size analysis of fine-grained sediments. J. Sediment. Petrol., 58:534-543.

Spencer, D.W., 1963. The interpretation of grain size distribution curves of clastic sediments. J. Sediment. Petrol., 33:180-190.

Stacey, M.W., and Bowen, A.J., 1988. The vertical structure of density and turbidity currents: theory and observations. J. Geophys. Res., 93:35283542.

Stanley, E.M., and Batten, R.C., 1969. Viscosity of sea water at moderate temperatures and pressures. J. Geophys. Res., 74:3415-3420.

Stow, D.A.V., and Bowen, A.J., 1980. A physical model for the transport and sorting of fine-grained sediments by turbidity currents. Sedimentology, 27:31-46.

Taira, A., 1989. Magnetic fabrics and depositional processes. In Taira, A., and Masuda, F. (Eds.), Sedimentary Facies in the Active Plate Margin: Tokyo (Terra Sci. Publ.), 43-77.

Taira, A., and Scholle, P.A., 1979. Deposition of resedimented sandstone beds in the Pico Formation, Ventura Basin, California, as interpreted from magnetic fabric measurements. Geol. Soc. Am. Bull., 90:952-962.

Visher, G.S., 1969. Grain size distributions and depositional processes. $J$. Sediment. Petrol., 39:1074-1106.

Date of initial receipt: 5 December 1995

Date of acceptance: 3 June 1996

Ms 155SR-202 